IZA DP No. 5731

Severance Pay Programs around the World:

History, Rationale, Status, and Reforms

Robert Holzmann

Yann Pouget

Milan Vodopivec

Michael Weber

May 2011 


\title{
Severance Pay Programs around the World: History, Rationale, Status, and Reforms
}

\author{
Robert Holzmann \\ World Bank and IZA \\ Yann Pouget \\ World Bank
}

Milan Vodopivec

World Bank and IZA

\author{
Michael Weber \\ World Bank
}

Discussion Paper No. 5731
May 2011

IZA

P.O. Box 7240

53072 Bonn

Germany

Phone: $+49-228-3894-0$

Fax: +49-228-3894-180

E-mail: iza@iza.org

\begin{abstract}
Any opinions expressed here are those of the author(s) and not those of IZA. Research published in this series may include views on policy, but the institute itself takes no institutional policy positions.

The Institute for the Study of Labor (IZA) in Bonn is a local and virtual international research center and a place of communication between science, politics and business. IZA is an independent nonprofit organization supported by Deutsche Post Foundation. The center is associated with the University of Bonn and offers a stimulating research environment through its international network, workshops and conferences, data service, project support, research visits and doctoral program. IZA engages in (i) original and internationally competitive research in all fields of labor economics, (ii) development of policy concepts, and (iii) dissemination of research results and concepts to the interested public.
\end{abstract}

IZA Discussion Papers often represent preliminary work and are circulated to encourage discussion. Citation of such a paper should account for its provisional character. A revised version may be available directly from the author. 


\section{ABSTRACT \\ Severance Pay Programs around the World: History, Rationale, Status, and Reforms ${ }^{\star}$}

The paper examines severance pay programs around the world by providing the first ever overview of existing programs, examining their historic development, assessing their economic rationale and describing current reform attempts. While a significant part of the paper is devoted to a comprehensive 183 cross country review of existing severance arrangements and their characteristics, the paper goes beyond a mere description. It develops and empirically tests three hypotheses about the economic rationale of the program, namely severance pay being: (i) a primitive income protection program, (ii) an efficiency enhancing human resource instrument, and (iii) a job protection instrument. The paper also reviews the recent reforms of Austria, Chile, Italy and Korea.

JEL Classification: J33, J65, K31

Keywords: $\quad$ severance pay, termination benefit, end-of-service benefit, termination benefits, seniority pay, indemnities, leaving allowances

Corresponding author:

Robert Holzmann

E-mail: rholzmann@worldbank.org

\footnotetext{
* A first version of the paper was prepared for the joint World Bank/International Institute for Applied System Analysis/Ludwig Boltzmann Institute for Economic Policy Analysis Workshop on Severance Payments, IIASA/Laxenburg, November 7 and 8, 2003 (see Holzmann, Ayer and Vodopivec, 2003). Subsequent attempts to complete the historic analysis and improve the inventory on severance pay proved more time consuming than envisaged; and the finalization of the paper was also delayed by other commitments and changes in positions. We are thankful to all to who contributed to its completion and review, in particular Zoran Anusic, Kripa Ayer, Gordon Betcherman, Annette Brown, and Don Parsons. All gaps and errors remain our own. The authors are academic and former sector director, economic consultant, lead economist, and economist, respectively, at the Human Development Network of the World Bank. The opinions expressed are those of the authors and not necessarily reflect the thinking of the Bank, or her senior management, executive board and member countries.
} 


\title{
Table of Contents
}

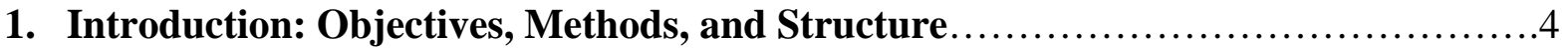

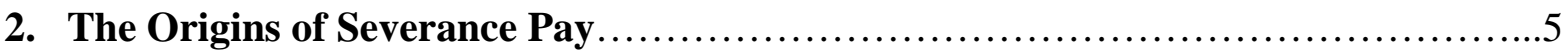

2.1 Severance Mandates: Three Explanations..................................5

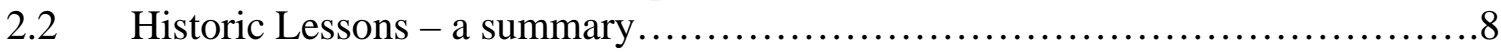

3. Mandated Severance Pay Programs: Modalities, Overview, Reforms..............10

3.1 How does mandated severance pay work?......................................................10

3.2 Overview of severance pay programs across the world......................13

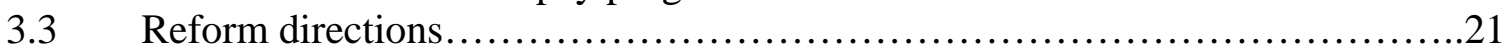

4. The Motivation behind Severance Pay: Reviewing Hypothesis and Evidence.......27

4.1 The Economic Rationale of Severance Pay.................................27

4.2 Determinants of the Incidence and Generosity of Severance Pay................29

4.3 Brief Review of the Efficiency Effects of Severance Pay.......................39

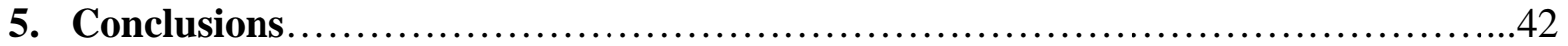

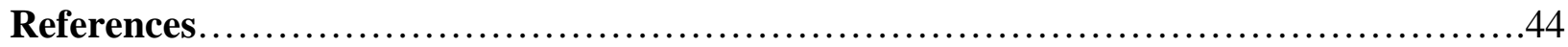

\begin{abstract}
Annexes
Annex 1: Historic Perspectives across Countries and Regions.............................51

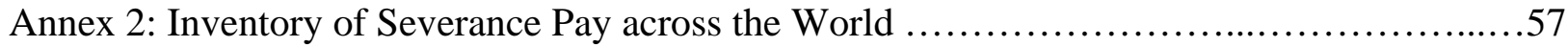

Annex 3: Note on Econometric Estimation............................................75
\end{abstract}




\section{List of Boxes}

Box 2.1 Railroad Workers and Severance Pay...........................................6 Box 2.2 Severance pay as Commitment Technology? An early example of the human resource

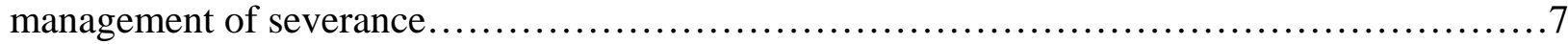

Box 3.1: Costs of Sri Lanka’s severance pay system.................................... 18

Box 3.2: Political economy complexities of reforming several pay program..................26

Box A-1 Golden Gate and Bay bridges - Job displacement and Severance Pay...................51

Box A-2 Severance pay in Mexico: Compensation for liquidated damages of job ownership....54

\section{List of Figures}

Figure 3.1a\&b: Incidence of Mandated and Quasi-Mandated Severance Pay Programs -

(a) by Country’ Income Levels(b) by Regions...............................................14

Figure 3.2a\&b: Incidence of Mandated Severance Pay Programs in Sectors

(a) by Country' Income Levels(b) by Regions............................................14

Figure 3.3a\&b: Eligibility Contingencies for Severance Pay (in percent)

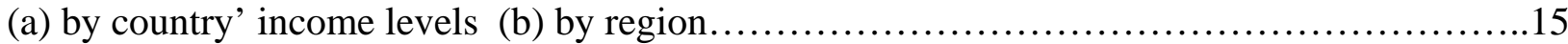

Figure 3.4a\&b: Vesting Periods for Benefit Eligibility (in months)

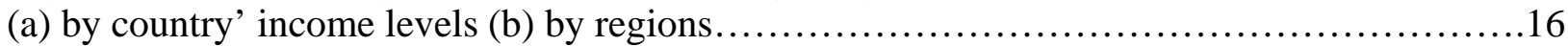

Figure 3.5a\&b: Severance Pay Generosity by Length of Service

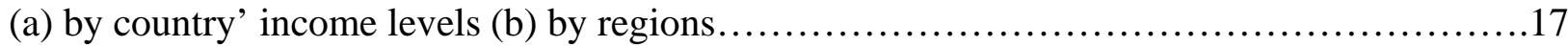

Figure 3.6a\&b: Severance Pay Generosity Index

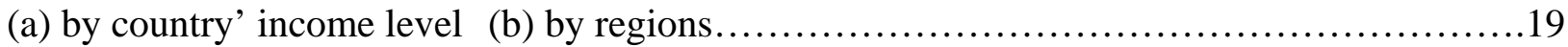

Figure 3.7a\&b: Funding Methods

$\begin{array}{lll}\text { (a) by country' income level } & \text { (b) by regions } \ldots \ldots \ldots \ldots \ldots \ldots \ldots \ldots \ldots \ldots \ldots \ldots \ldots \ldots \ldots \ldots \ldots \ldots \ldots \ldots \ldots \ldots \ldots \ldots \ldots \ldots \ldots \ldots\end{array}$

Figure 3.7a\&b: Taxation Rules

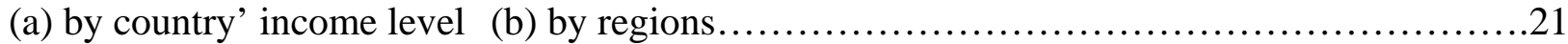

Figure 4.1a\&b: Generosity of Severance Pay and per-Capita GDP..........................30

Figure 4.1a\&b*: Generosity of Severance Pay and per-Capita GDP.........................31

Figure 4.2a\&b: Unemployment Benefit Generosity and per-Capita GDP......................32

Figure 4.3a\&b: Pension Benefit Generosity and per-Capita GDP ...............................32

Figure 4.4: Notice Period (in weeks) and per-Capita GDP....................................33

Figure 4.5a\&b: Generosity of severance pay vs. unemployment benefit generosity...............34

Figure 4.6a\&b: Generosity of severance pay vs. pension benefit generosity ....................35

Figure 4.7 Severance Pay Generosity and Notice Period.......................................

Figure 4.8: Severance Pay Generosity and Union Density.................................36

\section{List of Tables}

Table 4.1: Drivers of Generosity of Severance Pay: Results for Basic Model..................38 


\section{Introduction: Objectives, Methods, and Structure}

Severance pay programs exist in most countries around the world. They typically provide lump sum cash payments to workers who involuntarily or voluntarily separate from their employers. The size of the payment is usually related to the number of years worked with the last employer, and it is linked to the last salary in the job. Such payments were provided in many countries by employers before they were required by law. Firm-based severance pay schemes often also exist in parallel to legislated provisions. Moreover, firms may use voluntary severance pay programs as an important management tool for retaining skilled workers. In most cases, precedent for these programs existed before the introduction of formal social insurance schemes across the world, so severance payment systems may be considered a primitive form of unemployment compensation or pension allowance. Despite their widespread use, many aspects of severance pay programs including their origin, coverage, and interaction with other income support programs have not been well researched, particularly for developing countries. To the best of our knowledge, even the most basic descriptive information about severance payment schemes around the world has not been previously compiled.

One of the difficulties of examining the topic of severance pay is that different types of cash payments can be considered as forms of severance payments and many terms exist in English and other languages. Such terms include dismissal compensation, redundancy compensation, termination benefits, seniority pay, indemnities, and leaving allowances. While one can, in principle, assign special objectives to each benefit type (for example, dismissal compensation to involuntary job separation, and termination benefits to any kind of separation, including retirement), reality proves more complex as severance payments seem to serve multiple concurrent functions.

The objective of this paper is to review severance pay programs around the world by providing an overview of existing programs, examining their historic development, assessing their economic rationale, and describing current reform attempts. While the thrust of the paper is devoted to a comprehensive cross country presentation of existing severance arrangements and their characteristics, the paper goes beyond a mere description and develops and empirically tests three hypotheses about the economic rationale of the program, namely severance pay being: (i) a primitive income protection instrument, (ii) an efficiency enhancing human resource instrument, and (iii) a job protection instrument. The paper also reviews the recent reforms of Austria, Chile, Italy and Korea.

The rest of the paper is structured as follows: Section 2 examines the historic origins of severance pay and identifies competing economic justifications for its existence (details for more historically inclined reader are offered in Annex 1). Section 3 explains how the severance pay programs work by summarizing their stylized features, and then describes the complied inventory of existing severance pay programs around the world, explaining key features of severance pay programs, their broad characteristics as well as commonalities and differences between countries and regions. Details of programs in individual countries are presented in a comprehensive matrix in Annex 2. Section 4 discusses the economic rationale of severance pay, develops three hypotheses (that severance pay is a primitive income protection program, an efficiency enhancing human resource instrument, or a job protection instrument), and tests them with simple but robust econometric specifications. The concluding Section 5 offers a brief summary, policy implications, and suggestions for future research. 


\section{The Origins of Severance Pay}

While mandated pension, health and unemployment benefits and their historical origins are well known and documented, the same cannot be said for severance benefits. ${ }^{1}$ This Section aims to achieve a better understanding of severance pay by examining why these programs have been created in the first place. The section focuses on three key events that influenced the introduction of severance pay programs across the world - the introduction of national labor codes, early industrial restructuring, and the expansion of the welfare state after WWII - and alludes to key hypotheses proposed to explain the economic rationale of severance pay. The section ends with a summary of the historic lessons (further historical details can be found in Annex 1).

\subsection{Severance Mandates: Three Explanations}

The available literature on this topic ${ }^{2}$ suggests three main historical determinants of severance mandates across the world: (i) the creation of broader labor codes, (ii) early industrial restructuring and spells of high-level unemployment in the interwar period, and (iii) the expansion of the welfare state after WW II. These determinants are at times intermingled with two main reasons why firms choose to voluntarily provide severances pay: one-off payments during industrial restructuring to allow for quick action and to avoid political fall-out, and seniority-related payments - corporate pensions and severance - that balance the interest of firms and workers in knowledge intensive firms.

For developing countries, these historic events may not have had the same significance. Legislation in these countries seems to have arisen by copying of the colonial powers' labor codes and social security systems. Despite these common origins, actual system designs in developing countries are quite diverse and will be the focus of Section 3.

\section{Labor Code}

The first and main origin of severance payments is the creation of, and the link to, the labor code in the industrializing countries of the North in the 19th century. The birth of modern labor standards is traced back to 1802 when Sir Robert Peel introduced the English Factory Act. It was a symbolic act that placed restrictions on maximum working hours of apprentices. By 1875, both Britain and U.S. achieved complete legal equivalence in the relationship between employer and worker. The same is true for countries of Continental Europe around the same period. Each party was free to accept or reject offers, terminate contracts, and expect to pay damages if the termination amounted to breach of contract.

\footnotetext{
${ }^{1}$ Requests for information addressed to the International Labor Organization (ILO) and the International Social Security Organization (ISSA) produced some but limited information, as did selective requests with individual researchers. Special thanks go to Roddy Mckinnon from ISSA who helped dig-up some of the historical material.

${ }^{2}$ We came across the following literature dealing with severance-type payments in a historic perspective. For the US, UK, Japanese and some European origins and experience with severance or dismissal payments till the early 1940s, see Hawkins (1940, 1942). Historic hints and information after WW II are contained in two articles in the International Labor Review, with papers by Herz (1954) and Visisombat (1968). This second paper has information about the experience in French-speaking Africa. A book from this period (Meyers, 1964) provides information about the US. Recent writings on severance payments with historic references include Miron and Weil (1997), Basu et al. (2003), and Parsons (2005a,b).

What we did not come across and what may be an interesting and open research field concerns the role of social partners (trade unions and employers' organization) in the historic evolution of severance pay, and currently their role in the reform of severance pay, or the lack of it.
} 
Building on the limited nineteenth century civil codes, twentieth century legislatures took up the question of the regulation of employment contracts and intervened to secure protection for workers in case of dismissal. This was done by means of amendments to the civil, commercial or industrial codes, legislation on contracts of employment, and the promulgation of labor codes or even by special legislation with the sole object in view (Herz, 1954: 299-230).

It appears that severance payment at this time was granted if the notice period for dismissal was not respected by the employer. That is, dismissal payment was a compensation for breach of labor contract by the employer. As the notice period at this time was short, the non-codified severance payments can be expected to have been small.

\section{Early Industrial Restructuring}

The second main element for the emergence and persistence of severance payments were the technological changes of the late 1800s and the large-scale unemployment of the depression in the 1930s. Although fully developed dismissal compensation is almost entirely a post-WWI development, laws providing short periods of dismissal notice date back to the nineteenth century in several European countries.

It appears that issues of job security first emerged in the railroad industry. For example, in the 1870s and 1880s in France, a great number of railroad dismissal cases came to court and led to judgments that can be seen as important starting points for the establishment of severance pay. (See Box 2.1).

\section{Box 2.1 Railroad Workers and Severance Pay}

The case of railroad workers demanded particular attention because they worked in a new industry. Established industries had specific dismissal procedures, which were often tied to localities. Such norms were absent in the railroad industry. Moreover, railroad workers had highly specialized skills that tied them to working in railroads, and thus had weaker bargaining power vis-à-vis their employers. By training to work in the rail road industry, they limited their future to working in this specific area.

Cases of railroad workers also came to court because of pension problems, as workers could lose their pensions upon being fired. Severance pay may have served as an instrument to compensate for these losses. By 1890, laws had evolved to confirm the previous court rulings controlling for abuses of pension funds. Subsequently, legislation began to favor the granting of special job protection to railroad workers.

Throughout France, the practice of severance pay evolved through the lower courts, which recognized increasingly longer notice periods and greater indemnities for dismissed workers. Severance pay also covered a growing number of sectors. By the 1950s severance pay allowances already figured into white collar and supervisory employment. It also expanded to manual workers, as evidenced in national and regional plant agreements.

Source: Herz, 1954.

Following the end of WWI and the creation of the International Labor Organization (ILO) in 1919, legislation recognizing labor rights, and the establishment of various types of workers councils sprang up in Europe which protected workers in time of dismissal. In South and Central 
America definite provisions for dismissal compensation were introduced. In 1936, Japan adopted a contributory funded system for dismissal payments.

Greece established special regulations for workers displaced by cigarette machinery and for those dismissed because of new methods in handling cargoes in boats. In Germany, and before the Nazi regime, collective agreements had been widely adopted. In 1927, over 12 million people were covered by such agreements. Some employers adopted particularly innovative approaches to severance pay (see Box 2.2). At that time, also the French system focused on voluntary provisions secured through collective bargaining.

\section{Box 2.2 Severance pay as Commitment Technology? An early example of the human resource management of severance pay}

While there is little economic history evidence about how and why severance pay evolved, the case of the Carl Zeiss foundation in Germany stands out for its unique approach and enduring implications. It also provides one of the first documented cases of the use of severance pay (1889). Its social welfare approach responded to particular competitive circumstances, and exemplifies how severance pay might serve as a human resource management and efficiency enhancing instrument.

The Carl Zeiss foundation, the owner of the later world renowned producer of specialized glasses, offered paid vacation, sickness benefits, a nine hour working day, pension fund, and compensation in cases of dismissal. These seemingly overgenerous provisions actually held strategic value for both the firm and workers. The firm and worker both faced a challenge of establishing the trust required for a long term employment relationship. The employer was required to invest heavily in workers' training, which also made them more attractive to be poached by other employers who might offer higher wages. Employers would also suffer productivity losses and incur additional costs for recruiting and hiring new workers. To keep employees, the firm was required to pay a high wage premium, the pay exceeding the worker's actual productivity would render this approach unsustainable. Employers could also benefit from flexibility in dismissals given uncertain market conditions.

The actual experience of the Carl Zeiss foundation closely reflects these conditions. The firm's success depended on the implementation of highly technical and continuous training, which in turn required a long term relationship with employees. As Zeiss workers were sought after by competitor firms and labor was becoming more mobile, the stability of a long term employment relationship was threatened indeed. But uncertainties in this new market also implied that Zeiss workers faced the possibility of layoffs. In response the articles of agreement of the foundation (as the sole owner of the firm) guaranteed social obligations such as severance pay and pensions. The pension fund helped commit Zeiss workers to the long term employment relationship, especially as their pensions grew the longer they remained employed with the firm (the Zeiss pension fund grew almost tenfold between 1895 and 1905). With severance pay equal to a half year's salary, it also served as a significant deterrent to firing workers, since the costs incurred would be especially high for skilled workers (with more experience). Evidence suggests that both mechanisms helped produced, stable and long term employment relationships. A telling sign is also that during Germany's economic downturns of the 1930 s an unusually low proportion of workers depended on social welfare in Jena, home of Carl Zeiss.

Based on Abraham, M. and B. Prosch (2000). 
In April 1932, the governing body of the ILO approved a report of the unemployment committee favoring dismissal compensation for salaried employees. The Advisory Committee on Salaried Employees stated in 1936, "in countries where formal rules are not in existence they should be introduced by legislation or collective agreements.” By 1940, around forty countries had passed laws providing notice or compensation for dismissed industrial workers or salaried employees. Until 1940, severance payments were generally only for salaried employees but in countries with no unemployment insurance programs the trend was to include all workers. Many companies' plans initially were adopted to meet particular situations such as technological displacement. Legislation later became broader in its coverage.

\section{Introduction and Expansion of the Welfare State}

The economic, social and political events of the interwar period and World War II were the third critical component to the introduction and expansion of the welfare state. It led to the legislation of key social security programs in order to address key contingencies in the post-war period of formal sector workers. These benefits in cash or kind to the benefit of employees were now typically legislated outside the labor code or similar legislation. Coverage expanded to a greater share of the labor force with improved eligibility conditions and increased generosity.

This expansion affected formal sector workers across the world and had also a bearing on severance pay in coverage and generosity. The scope of coverage of severance pay was often increased in parallel to the expansion of social security benefits. Social insurance coverage expansion proved difficult and unemployment insurance not advisable in low and middle income countries with a large informal economy. This gave rise to expansion of severance pay programs to larger group of workers or improved generosity, or provisions that have main similarities with severance pay, but are typically legislated outside the labor code. Unemployment insurance savings accounts introduced in Latin America belong to them (see Ferrer and Riddell, 2011).

Developing countries of the decolonizing South often inherited or copied the laws and regulations from the former colonial powers. For a number of other instances it has been suggested that the provision of severance pay in a number of developing countries was deemed a transient legislative measure, the need for which would decline with the development of fuller employment policy and an extensive social security system emulating the development in the North. For example, the provision of severance pay was "subject to this obligation coming to an end on the promulgation of legislation concerning social insurance (Costa Rica) or to the replacement of compensation by benefits from a welfare fund (Dominican Republic, Egypt, Lebanon, Syria); see Herz (1954: 319).

Among what were to become (former) Soviet countries, only for Estonia did we uncover evidence of early severance pay legislation (1934 and 1936). Severance pay or dismissals for that matter were essentially meaningless during the Soviet times and unemployment insurance did not exist. Employees could only be dismissed for extremely limited reasons, each of which required different, complex dismissal procedures. With the transition to the market, all countries adopted new severance pay legislations and unemployment benefit.

\subsection{Historic Lessons - a summary}

A number of features emerge from the historic accounts that are useful to understand the reason for the complexity of severance pay arrangements. These features also shed light on the 
development of these arrangements over time in and across countries and eventually helped to guide the development of the cross-country inventory but also inspired the analysis.

The historic overview of the prior Section and Annex 1 suggests the following features:

- Many severance pay disbursements occurred during large-scale industrial restructuring, with provisions directly negotiated between firm and workers (trade unions) in an ad-hoc manner and adjusted to the specific restructuring process. They often happened outside legislated rules or collective agreements.

- There are various firm-based indications of how severance pay provisions together with occupational pensions have been used early on in knowledge-intensive sectors to establish a commitment technology both for employer and employee. The loss of an occupation (defined benefit) pension for early leavers was balanced with severance pay commitments and hence firing costs for the employer.

- Firm or industry-specific agreements still play a role in most countries above and beyond legislated rules or collective agreements with little information about the terms of references. In some countries, most prominently Germany, Japan and the US, they are the basis of severance pay as a mandated scheme does not exist.

- Mandated severance pay provisions are a primitive form of social protection. They were introduced in most but not all countries prior to other social protection mechanism, in particular unemployment and retirement benefits.

- In developed economies severance pay was not abolished once related social security benefits had been established. In most developing countries severance pay is still the key provision for the formal labor force as access and eligibility to unemployment and retirement benefits remain limited.

- In countries with limited formal sector employment, severance pay is often seen as a key instrument for job protection. Severance pay together with long notice periods and firing restrictions serve to protect workers in formal jobs from the main income loss in case of a dismissal.

- The difference in coverage for unemployment and pension benefits between developed and developing economies suggests that the rationale for severance pay, its design features, and its interactions with related social benefits are different. This suggests a need to differentiate conceptual frameworks between high and low income countries. Middle income countries have characteristics for some group of workers closer to the first, for others closer to the low income group. 


\section{Mandated Severance Pay Programs: Modalities, Overview, Reforms}

Building upon the historical background of the prior Section, a cross country inventory of mandated severance pay and related variables has been established (Annex 2). It attempts to present comparable information on the highly complex severance pay provisions that address key features for analysis and policy reform. The annex contains more detailed information from 2010 or latest information about mandated severance pay itself and about a variety of other country characteristics, including related social benefits, labor regulation, and the economic environment. This Section starts with a review of key features of the severance pay system, and then continues with review of existing severance pay programs throughout the world.

\subsection{How does mandated severance pay work?}

Severance pay mandates require that firms make payments to workers upon separation from the firm. As with other cash benefit programs, many issues arise in the design of severance pay. Most fundamentally, under what conditions should the government preempt voluntary and collectively bargained severance plans, and mandate its own? Which workers should be eligible for the benefit, under what contingencies, and with what level of benefits? How are the benefits to be paid? Moreover, under the compulsory systems, which types of firms are obliged to pay for it? What happens if the firm is unable to make such payments due to insolvency? Are there any financing arrangements which facilitate such payments? Below we discuss the main modalities found in mandated severance pay plans when dealing with the above issues.

Legal Source and Coverage: Severance pay can be mandatory, i.e. required by law, usually established by the labor code; based on collective agreements established at industry or national level; and voluntary - if firms themselves decide whether to make such payments or not. One can obtain a rather good information about mandated schemes, very incomplete information about collective agreements, and none about voluntary schemes. As a result, the presented benefit features apply to mandated schemes only. Mandatory programs may apply to all employees, to the private sector only, or to specific industrial sectors or occupations. Moreover, some countries limit mandatory programs only to firms above a certain size threshold, as larger firms are deemed better able to incur such expenses. The information in the inventory highlights sectors (all or private only), and the excluded categories, if the information is available.

Eligible Contingencies: In some countries, mandatory severance pay is required for all types of separations, but in other countries some types of separation may disqualify workers. For example, workers dismissed due to misconduct (who separate by their own fault), and those who (voluntarily) quit, typically do not qualify for the entitlement. Again other countries provide mandatory severance pay only to workers who are discharged due to redundancy (economic) reasons but not for other valid reasons (dismissal), and yet others mandate severance pay only for cases of collective dismissals, or for certain groups of workers (such as white-collar workers). In the inventory we differentiate between six main contingencies giving rise to eligibility: dismissal, redundancy, bankruptcy, disability, retirement, and end-of service. The first four are involuntary separations, the last two voluntary. In case of severance saving provisions based on individual accounts, typically all separating workers can - regardless of the reason for separation - make some withdrawals from their individual accounts.

Parsons (2011b) makes the important distinction between severance insurance pay and severance insurance savings, arguing that these are polar cases of a continuum, with actual provisions 
spread across the spectrum. On the one side is the indemnity for dismissal, i.e. a compensation for losing the job by employer decision to severe the contract. On the other side is a payment that is due whenever the individual leaves the firm (end-of-service pay). The more contingencies give rise to eligibility, the more the severance pay moves from an indemnity insurance to a savings provision, with implications for hiring and firing costs for the employer (Parsons 2011a).

Benefit Type and Benefit Level: Severance pay has traditionally been of the defined benefit type and most designs remain of this form. Increasingly, however, defined contribution benefits are being introduced. Under defined benefit plans, severance pay depends usually on the years of service and last wage, and has in most cases a vesting period, i.e. requiring a minimum number of months of employment for eligibility. Typically, each year of service is rewarded in proportion to the individual's wage, for example, by half of the individual's monthly wage per each year of service. More complex formulae exist wherein compensation is adjusted according to years of service and/or age tiers. Under such structures, individuals with long records of service and/or older age are usually entitled to more generous severance pay. In some countries, the generosity of severance benefits may differ by the type of separation (e.g. dismissal, redundancy, collective redundancy, end-of service), between white- and blue-collar workers, permanent and fixed-term workers, and those covered by collective agreements and those not covered. In some countries workers receive a seniority premium, depending on the reason for separation (usually in cases of non-fault dismissals). Some countries do not have explicit benefit formulas and leave determination of the severance pay, as well as the authorization to lay off workers, to special government bodies or court decisions.

For defined contribution arrangements the benefit level depends on the contribution rate, the contribution base (wage) and the interest rate earned. Eligibility typically does not depend on cause of separation albeit the immediate access and size of the available resources may.

As a rule, severance pay is paid in a lump-sum fashion (but it can also be paid in regular monthly payments - see the description of the new Austrian severance pay system below). In countries where employers contribute to individual unemployment accounts, payments could be deferred until retirement (and could conceivably be converted to annuities).

Funding and Taxation. In general, severance pay is financed by employers. In countries with individual accounts, workers may also contribute. In some countries, the government provides financial assistance, particularly for large-scale restructuring operations which involve worker retrenchment in mass layoffs.

The type of funding of severance pay has a bearing on incentives for employers and employees, including their trust in the arrangement. There are four broad types of funding:

- Internal and current funding of severance pay, i.e. full payment out of current revenues at the time of separation, treating them as additional current wage expenditure;

- Internal funding with book reserves within the firm, with the provisioning partially or fully tax exempt, where the latter at times made dependent on assets bought as collateral (say government bonds);

- External provisioning via individual accounts held by financial market institutions (insurance company, commercial bank, or specialized institutions);

- External provisioning through centralized and typically government institutions.

Various considerations apply when deciding about which type of funding to use. Financing severance pay out of current cash flow creates a challenge for smaller employers even in good 
times, and a non-payment threat for the worker in case of insolvency of firms of all size. In countries with weak legal foundations the non-compliance by employers - even if solvent and liquid - is reportedly not an uncommon event that risks making any notionally generous benefits largely irrelevant. In order to address the solvency and liquidity risks some countries have established special guarantee funds. Reserving internally may provide some limited protection but it may offer benefits for both firm and employee, in particular with underdeveloped financial markets. Firms have additional self-financing and workers may profit from a higher rate of return (wage growth) than achieved on the financial market. External provisioning with financial market institutions reduces the compliance, liquidity and solvency risks with the firm but exposes the worker to other risks, in particular the solvency risks and the financial market risks, including low rates of return. External provisioning with centralized government institutions may better insure against liquidity and solvency risks but government funds, in general, have a bad track record on financial performance (Iglesias and Palacios, 2001).

Severance benefits may be subject to different types of taxation and broadly three types can be differentiated: they may be tax exempt; partially taxed through tax allowances, ceilings or special rates; or fully taxed as normal wages or income. Severance payments made by employers are typically but not always fully deductible as business expenditure (as wages are). Any difference in tax treatment - full deductibility by the employer and non full taxation of severance pay by the employee compared to wages - invites tax arbitrage and collusion.

Our inventory matrix of mandated severance pay programs around the world presents also several variables on country environment, as they may help explain both design features as well as the labor market effects of severance pay. Many country features could be identified but the following are especially important:

- The level of informality, which is closely, but not fully linked with per-capita income;

- The level of labor market regulation, in particular the dismissal process and the length of the dismissal notice;

- The scope of coverage and level of social benefits (or their absence), in particular for unemployment and old-age benefits;

- The development of the financial market as enabling condition for some funding options;

- The strength of trade unions across the country and in specific sectors.

The level of formality has a bearing on both the coverage for retirement and related benefits as well as the type of unemployment benefits. In an economy with high informality, a typical unemployment insurance scheme is unlikely to work as the status of the unemployed cannot be easily observed, would create major moral hazards, and as a consequence is rare. This enhances the importance of severance unemployment income protection (together with tighter dismissal regulation as employment protection). In case of no or limited access to retirement benefits, severance pay are may also be used as a retirement income mechanism, often with no limitations on the number of years that are used for its calculation.

In the analysis of the effect of labor market programs on labor market outcome, the generosity of severance together with other social benefits (measure through the level of social payroll taxes) and advance notice and other components is often lumped together into an index to measure the strength of Employment Protection Legislation (see, e.g. Heckmann and Pages, 2004; OECD, 1999; Haltiwanger et al., 2008). To allow for testing of some hypotheses and to encourage 
further analysis by the academic community on the scope and design of severance pay, the inventory includes data on some of these variables.

\subsection{Overview of mandated severance pay programs across the world}

Below we describe the salient features of the mandated severance pay programs around the world. To be as comprehensive as possible, we base our data base on the broadest collection of mandated severance pay schedules currently available (World Bank, Doing Business 2011), which covers 183 countries. This offers almost complete coverage of countries and allows us to assess regularities of severance pay in relation to broad country characteristics (such as GDP per capita) although some features are not well covered in a number of countries (e.g. on taxation of benefits or level of informality). For these characteristics we have collected comprehensive and up-to-date information but at times had to make judgment calls between comprehensiveness and full comparability. We will note these in the text and in the comments of Section in Annex 2.

Scope of the coverage: Except in low-income, predominantly African and Pacific islands countries, most countries have either mandatory or quasi-mandatory severance pay systems. The information on the latter is incomplete: We have information for countries with comprehensive collective agreements and for those with essential absence. Of the 183 countries in the inventory, 152 have mandated schemes (82 percent), 18 have quasi-mandated schemes through comprehensive collective agreements, and only 13 (7 percent) have neither. At least 22 countries have both mandated severance pay and coverage under comprehensive collective agreements. For another 44 countries, available information suggests no or little coverage under such agreements. This leaves 98 countries for which we have no information on the scope of collective bargaining provision of severance benefits.

The presence of mandatory severance pay systems varies broadly with the income level of the country (Figure 3.1, panel a). ${ }^{3}$ The lowest share of mandated severance pay (70 percent) and the highest share of collective agreements when mandated provisions do not exist (almost 100 percent) are found in high income countries. In contrast, low income countries have the highest mandated share (almost 95\%) and no known comprehensive collective agreements. Upper middle income countries have high shares of mandated provisions. With respect to regions ${ }^{4}$, severance pay is mandated in nearly all transition countries and about 90 percent of African, Middle East and Latin American countries. Only 2/3 of OECD and Asian countries have them, with the absence of mandates concentrated in the Pacific Island countries (Figure 3.1, panel b). In contrast, quasi-mandatory systems are well-represented only in high-income/OECD countries (where about 40 percent of countries have them). All OECD countries have either mandatory or quasi-mandatory system, although overall coverage may be low, as in the U.S. which has no mandatory severance and low collective bargaining density.

3 For the country' income grouping and thresholds, see http://data.worldbank.org/about/countryclassifications/country-and-lending-groups.

${ }^{4}$ The country grouping is done by expected main similarities and deviates in some aspects from the World Bank institutional classification. OECD covers old and new member countries (such as Mexico and Chile in Latin America and the Caribbean, and Czech Republic, Hungary, Poland and Slovenia from Europe and Central Asia ECA); Transition covers countries both from other ECA and Asia (such as China and Vietnam); Asia covers both South and East Asia and the Pacific Islands; MENA the countries in the Middle East and Northern Africa; finally, Africa covers the countries south of the Sahara. 
Figure 3.1a\&b: Incidence of Mandated and Quasi-Mandated Severance Pay Programs (a) by Country’ Income Levels

(b) by Regions
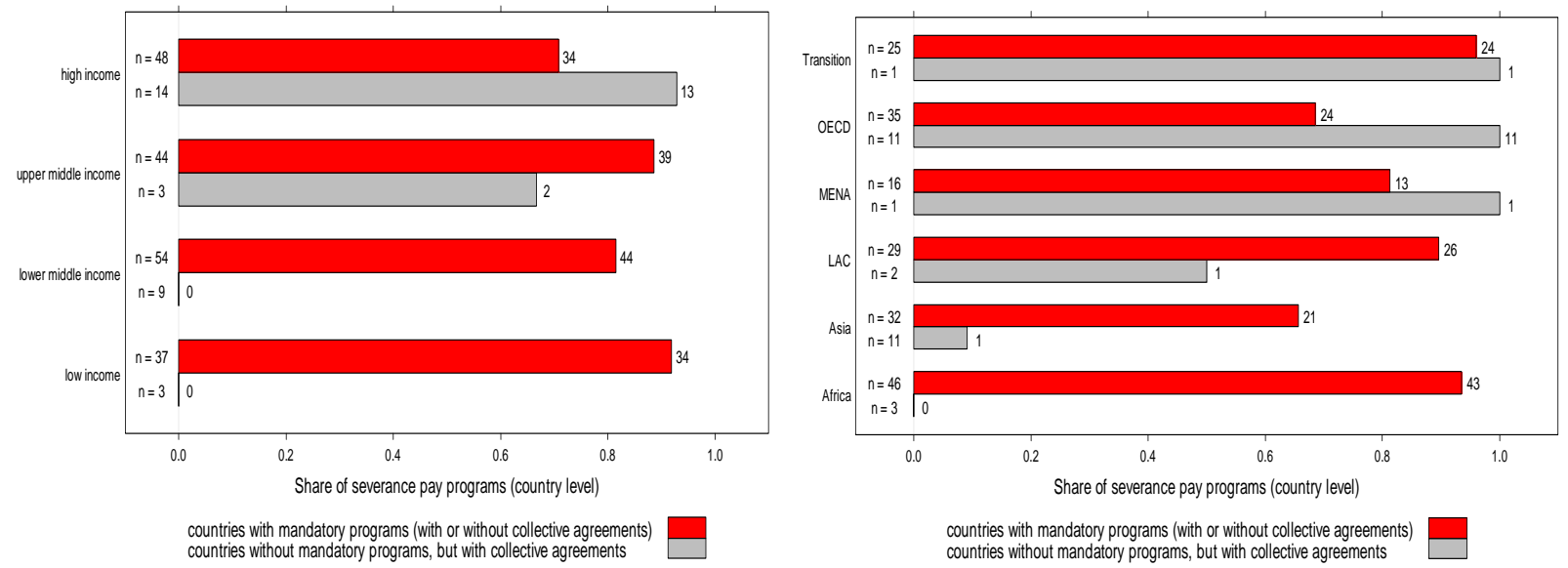

Source: Annex 2

In most countries severance pay programs cover primarily the private sector and the share is particularly high among OECD countries where it reaches almost 80 percent (Figure 3.2, panel a and b). This may be explained by the special status enjoyed by public employees who have highly protected employment positions. In the transition economies of Central and Eastern Europe, however, 70 percent cover all employees. In these countries a special employment position for civil servants did not exist during communist times and was not introduced with the move towards the market. In Africa and Asia, some 50 percent of countries mandate severance pay in all sectors. While in most countries firms of all sizes are covered, some countries limit coverage to firms with more than 5 workers (Colombia, South Korea until 2011), 10 (Germany, Morocco, Nepal, Slovenia, Venezuela), 15 (Australia, Italy, Kyrgyz Republic, Sri Lanka), 20 (Bulgaria, Denmark, Finland, Hungary, Pakistan, Poland, Switzerland), 30 (Turkey) and even 50 (India) - see Annex 2.

Figure 3.2a\&b: Incidence of Mandated Severance Pay Programs in Sectors (a) by Country' Income Levels

(b) by Regions
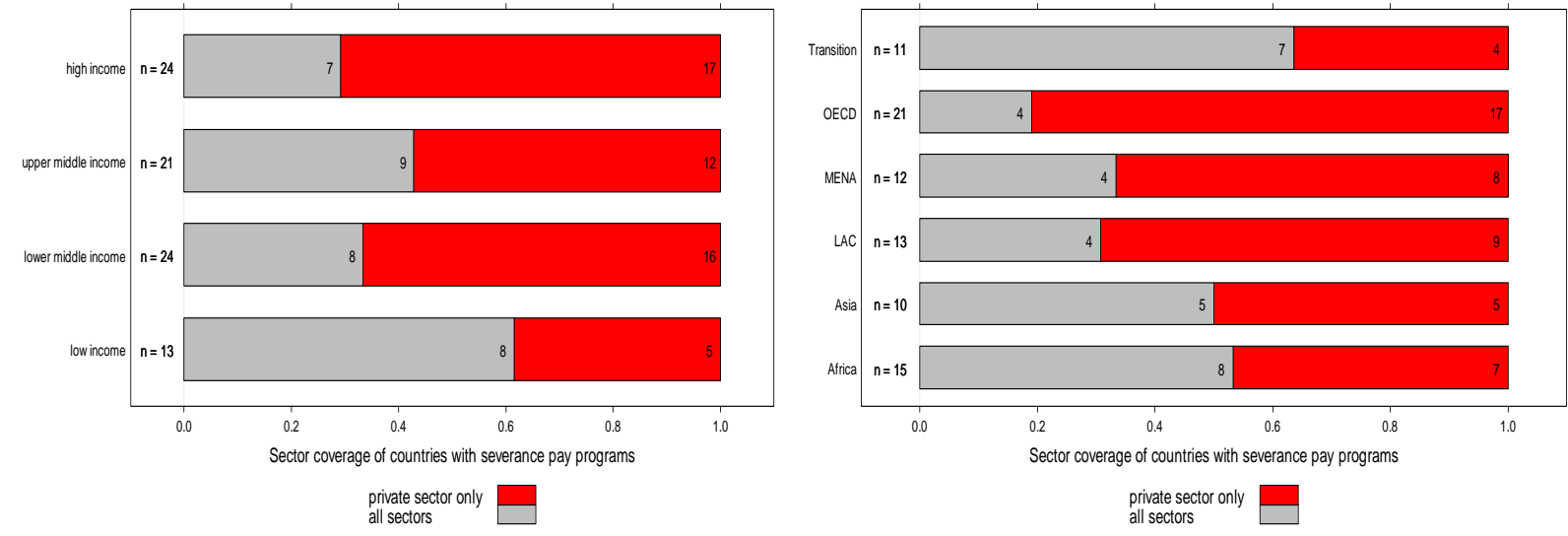

Source: Annex 2

Eligible Contingencies. The vast majority of countries with mandated schemes base benefit eligibility on the traditional contingencies - dismissal and redundancy. They account for the majority of all countries, with only modest differences across income levels and regions. If 
presented by level of income, redundancy reasons are more prevalent than dismissal reasons; this is more blurred if presented by regions (Figure 3.3, panel a and b). For many of the 152 countries that mandate severance pay, redundancy and other eligibility conditions can be separated. For 46 countries we know at least the redundancy criteria but not the others, hence they are put into an own category ("redundancy \& unknown"). Explicit reference to bankruptcy and incapacity is made in some 10 percent of the countries only, in the transition economies in 20 percent. Old age (retirement) as an explicit contingency exists in only few countries that are most clustered around the upper-middle income level and Latin America. The prevalence of end-of-service pay rises with the income level of countries from nil in low income to almost 30 percent in high income countries. At the regional level, end-of-service pay is most prevalent in MNA countries where it reaches above 50 percent, followed by the OECD with some 30 percent.

Figure 3.3a\&b: Eligibility Contingencies for Severance Pay (in percent)
(a) by country' income levels
(b) by regions

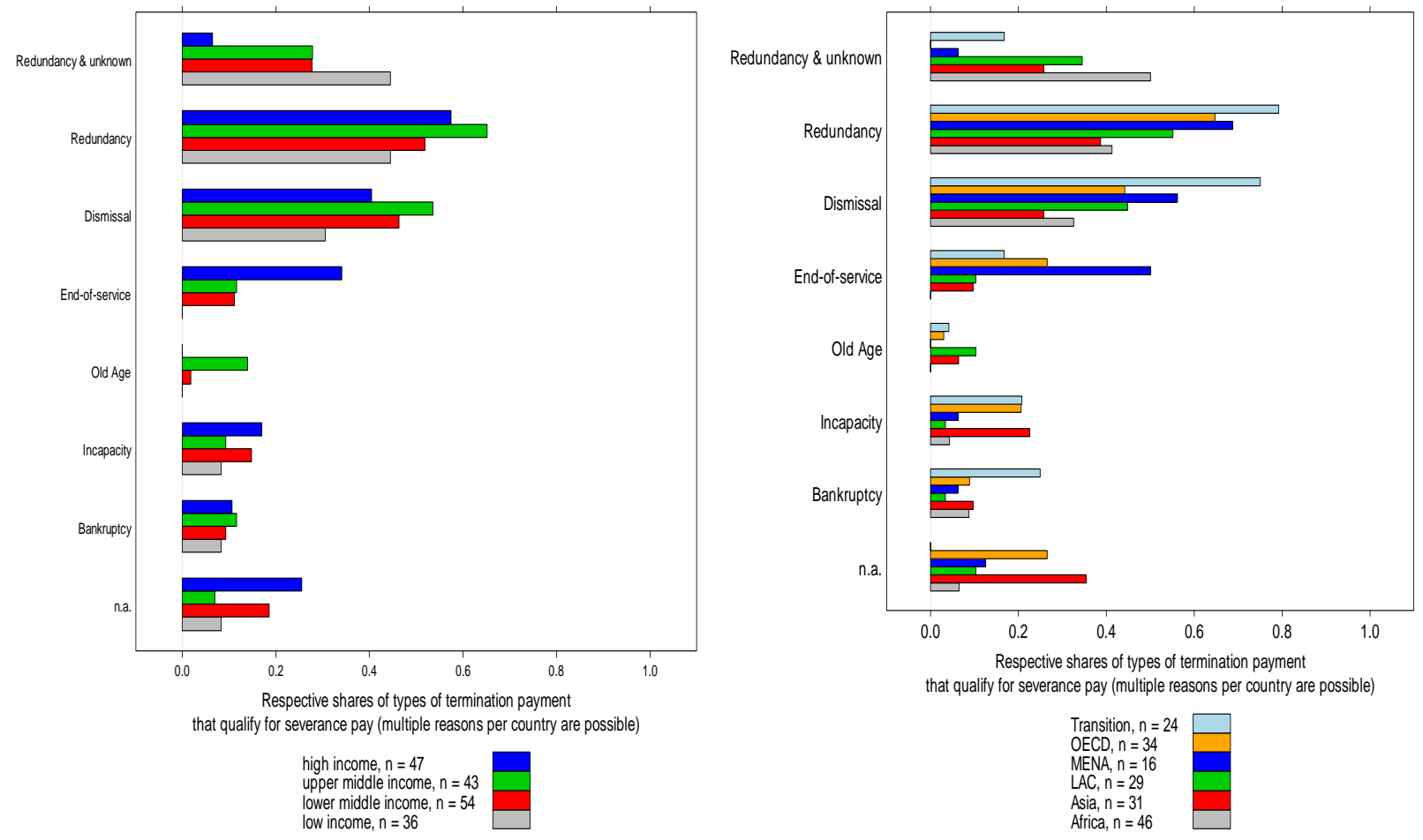

Source: Annex 2

A critical further eligibility condition for severance pay is the vesting period, i.e. the minimum number of months of employment required before the benefit formula becomes operative. While these minimum service requirements (in months) differ little in median values across income levels, means increase sharply with income level, from 10 months in low income to 33 months in high income countries (Figure 3.4, panel a and b). This is also reflected across regions, with OECD countries showing the highest mean level. What is striking in the regional comparison is the low median for Latin America (3 months) and the high value for the OECD countries Switzerland (240 months) and Denmark (144 months) which strongly influence the average for the OECD group. The high vesting periods suggest a different role of severance pay that may be 
linked to the importance of corporate pensions in both countries. Without these two countries the average for OECD would actually be 17 months. ${ }^{5}$

Figure 3.4a\&b: Vesting Periods for Benefit Eligibility (in months)

(a) by country' income levels

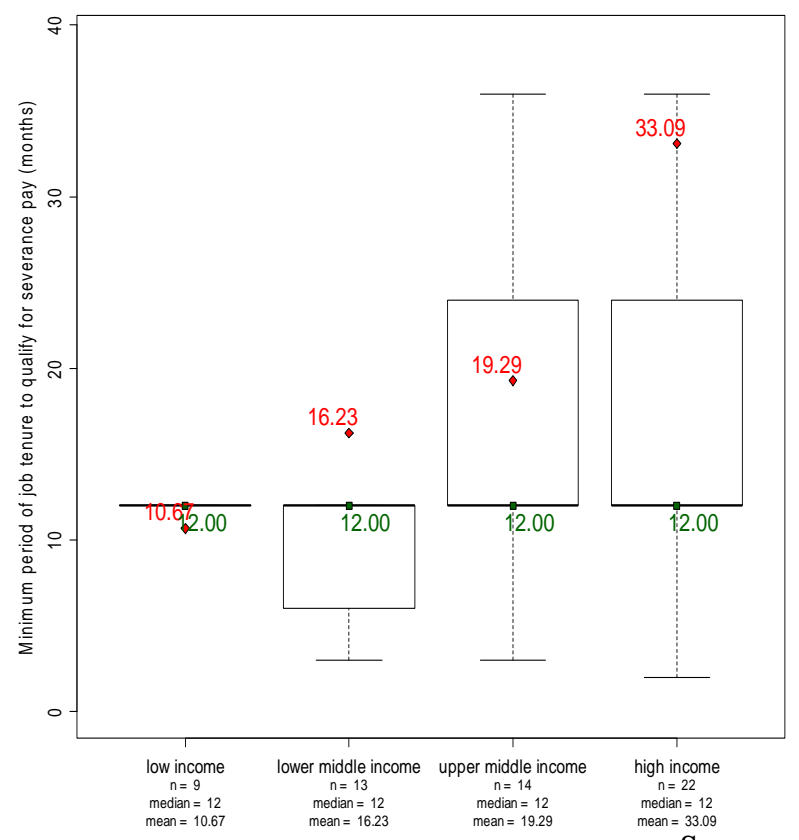

(b) by regions

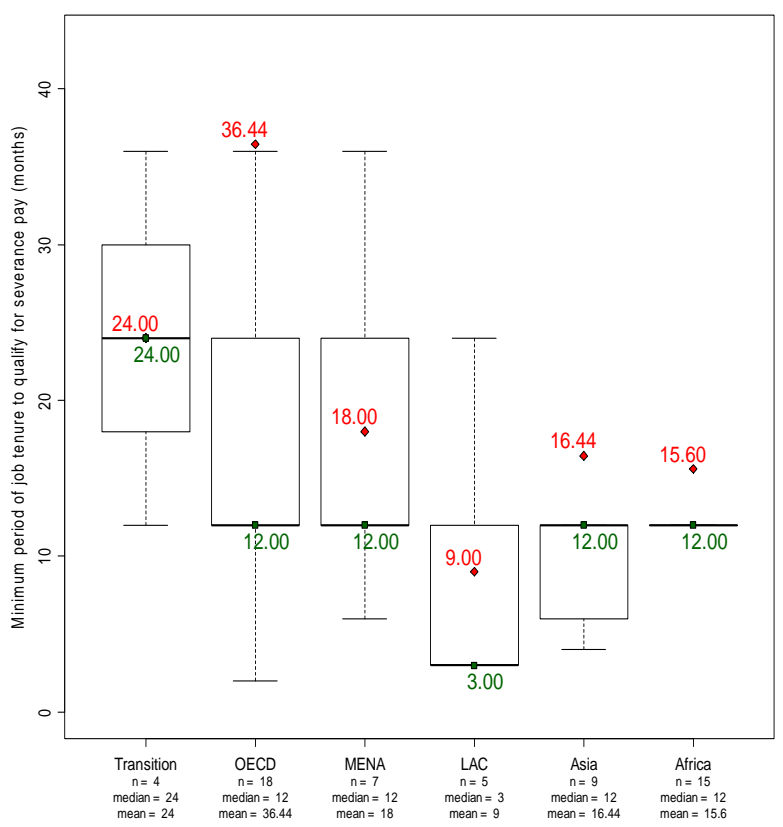

Benefit level. We focus in this section on (mandated) benefit levels for redundancy, i.e. employer-initiated separation for economic reasons. This benefit has the most comprehensive information base; it is the most important contingency; and it is also the most relevant benefit from a policy perspective. In most countries the benefit formula is in any case uniform across contingencies although in a few benefits differ across contingencies in a complex manner. Annex 2 provides detailed information for redundancy benefits at different points of service length (1, 5, 10 and 20 years) as well as on the benefit formula (defined benefit and defined contribution) for end-of-service benefits for those few countries where they are reported to exist.

The generosity of severance pay varies strongly across countries and in a manner that is closely linked with income level. Almost universally and for all presented length of services, low income countries offer the highest and high income countries the lowest level of generosity. Generosity is monotonically decreasing for median as well as mean benefit levels. Measured at 1 year of service and looking at the median benefit, it amounts to 2.2 weeks for high income countries and almost double that ( 4.3 weeks) for low income countries. For 20 years of service, the mean benefit level increases from 37.58 weeks to 68.95 weeks). (Figure 3.5, panel a). The regional distribution also reveals unsuspected variance: the highest generosity (except for low-tenured workers) is found in Asian countries, followed by Africa, MENA, and Latin America (Figure 3.5, panel b). Indeed, at the top of the scale (paying 80 weekly wages or more to a worker with

\footnotetext{
${ }^{5}$ In Figures 3.4 to 3.6, the numbers in red are the mean values, those in green the median values (Quartile 2). The box contains $50 \%$ of the data. The box size is therefore defined by the Inter-Quartile Range (IQR), the difference between Quartile 1 and Quartile 3. The whiskers (upper and lower bars out of the box) are defined as 1.5 times the IQR in both directions. See http://www.statmethods.net/graphs/boxplot.html and McGill (1978).
} 
20 years of service) are 14 African countries, 11 Asian countries, 8 Latin American countries, 4 MENA countries and 2 OECD countries (Portugal and Turkey). One of the most costly systems is offered in Sri Lanka, with the maximum amounts in 2001-02 reaching 36-50 monthly wages (see Box 3.1) and currently standing at 169 weekly wages for redundancy pay (some 40+ monthly wages). On the other end of the spectrum - offering the least generous severance pay are transition countries (this conclusion does not hold for low-tenured workers, who in transition economies are entitled to higher severance pay than in other groupings).

Figure 3.5a\&b: Severance Pay Generosity by Length of Service (a) by country' income levels (b) by regions
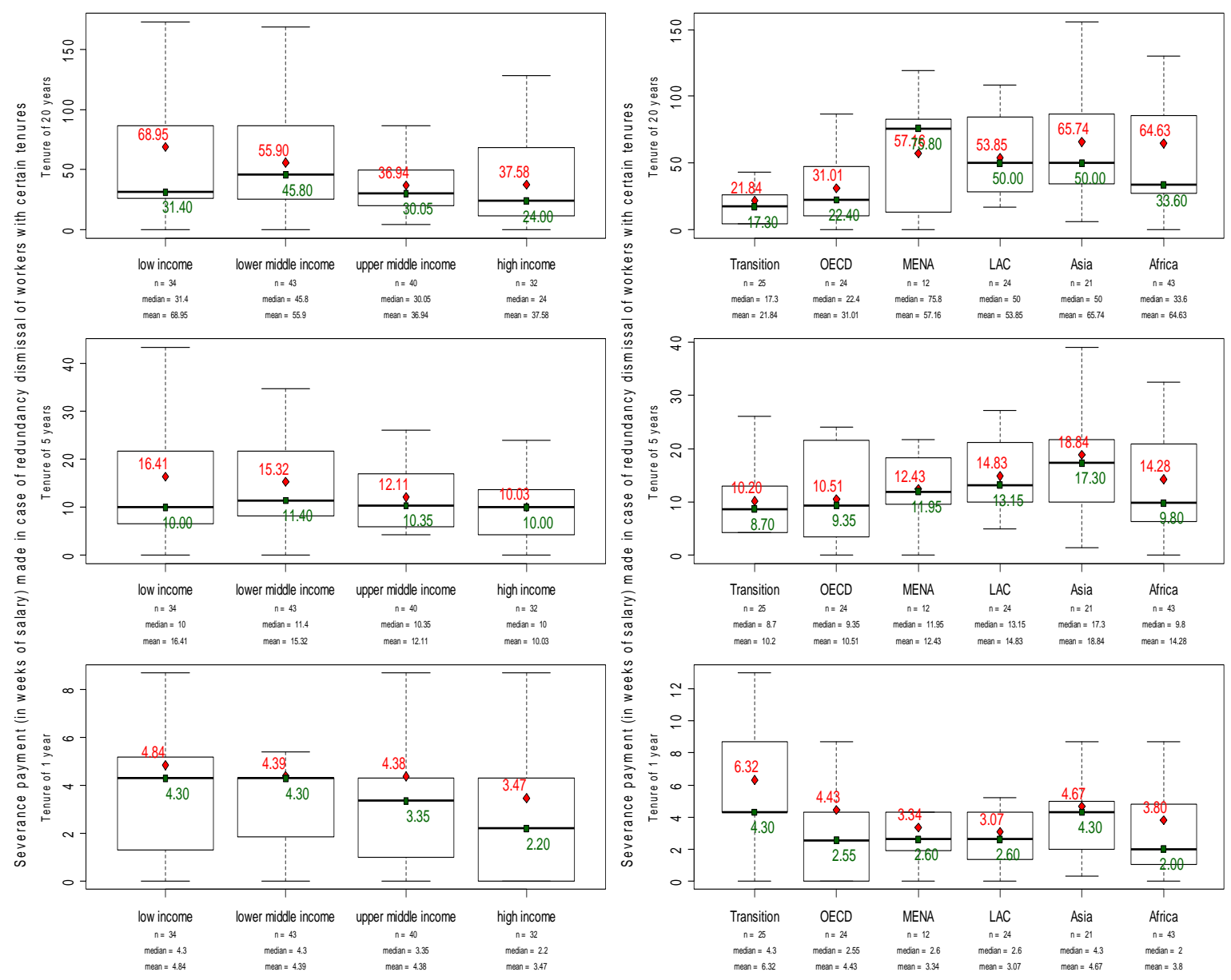

Source: Annex 2

Another way of looking at the generosity of severance pay is to examine the ratio of the number of weekly wages paid per year of service. For such a Severance Pay Generosity Index we aggregate the benefit schedule by average benefit levels at 1,5 and 10 years of service and normalize by the years of service. ${ }^{6}$ Hence a value of larger than 2 signifies that on average a

\footnotetext{
${ }^{6}$ Clearly the choice of years of service is arbitrary and the equal weight biases the result compared to empirical weights reflecting actual distribution of benefit payment by service length. This information, however, is not available.
} 
worker with equal probability to be made redundant after 1, 5 and 10 years of service would

\section{Box 3.1: Costs of Sri Lanka's severance pay system}

Sri Lanka's severance pay system imposes one of the highest costs internationally. It not only provides extremely high compensation to laid off workers and inflicts correspondingly high costs on employers, but its discretionary nature and non-transparency impose additional costs by generating uncertainty about the ability to lay off workers (the government has the authority to reject employer's demands) and lengthy procedures.

The Termination of Employment of Workman Act (TEWA) of 1971 requires employers with more than 15 workers to inform the Commissioner of Labor about their intended layoffs - and obtain the Commissioner's authorization for doing so (for each individual case, not only for mass layoffs). The act requires that the request is examined and response provided within three months, but it does not determine the compensation to be provided for the laid off workers. In addition, there is another severance payment called gratuity (Gratuity Act No. 12 of 1983) paid by employers. Companies with more than 15 employees have to pay gratuity to all workers upon termination of their employment, provided that they have more than 5 years of services with the employer. Gratuity payments amount to one month salary for each 2 years of service.

In practice, the level of compensation under TEWA approved by the Commissioner has been up to a maximum of 6 monthly wages per year of service, and the average was 1.6 and 3.1 monthly wages per year of service in 2000 and 2001, respectively (ILO, 2003). The total sums paid out to laid off workers have been large, with the maximum amounting to 36-50 months of wages (ILO, 2003). Moreover, the time needed for processing the Commissioner's request has been unpredictable, taking on average 6 months, and sometimes much more. What is more, the procedure has usually involved hearings, where employers explained their financial performance and business plans to government bureaucrats to justify the layoffs.

Source: Vodopivec (2004).

expect to receive more than 2 weeks of wage for each year worked (Figure 3.6a\&b).

For low-income countries the generosity index is 3.46 and falls gradually to 2.81 for lower middle, 2.73 for higher middle income, and 1.84 for high income countries, if measured at mean benefit level. Measured at median level the fall with income level is less pronounced, except for high-income countries. Across regions, the highest average value can be found for transition economies (3.27) followed by Africa (2.97) and the lowest in OECD (2.12) if measured at mean value, and LAC (2.5) and MNA (2.45) versus OECD (0.7) if measured at median value (Figure 3.6, panel b).Another aspect of the generosity is the mandated maximum amount of the severance pay. The available evidence suggests that the maximum severance pay benefit in some countries may reflect any number of years (say 40 month salary for 40 years); yet this is more the exception than the rule. The service limits in the benefit formula are typically much lower.

It has to be emphasized that the severance pay benefit levels presented above do not include seniority premiums. That is, additional payments required to be paid in some countries in cases of non-fault dismissals (dismissal "without just cause," which typically include separations for economic reasons). Such payments are quite common in Latin American countries (Brazil, Colombia, Ecuador, Panama and Peru). Note that such an additional compensation has a clear connotation of a penalty for a firm, which means it can be closely associated with the job protection function of the severance pay program (see Section 4.1 on different hypotheses about the economic rationale for severance pay programs). 
Figure 3.6a\&b: Severance Pay Generosity Index

(a) by country' income level

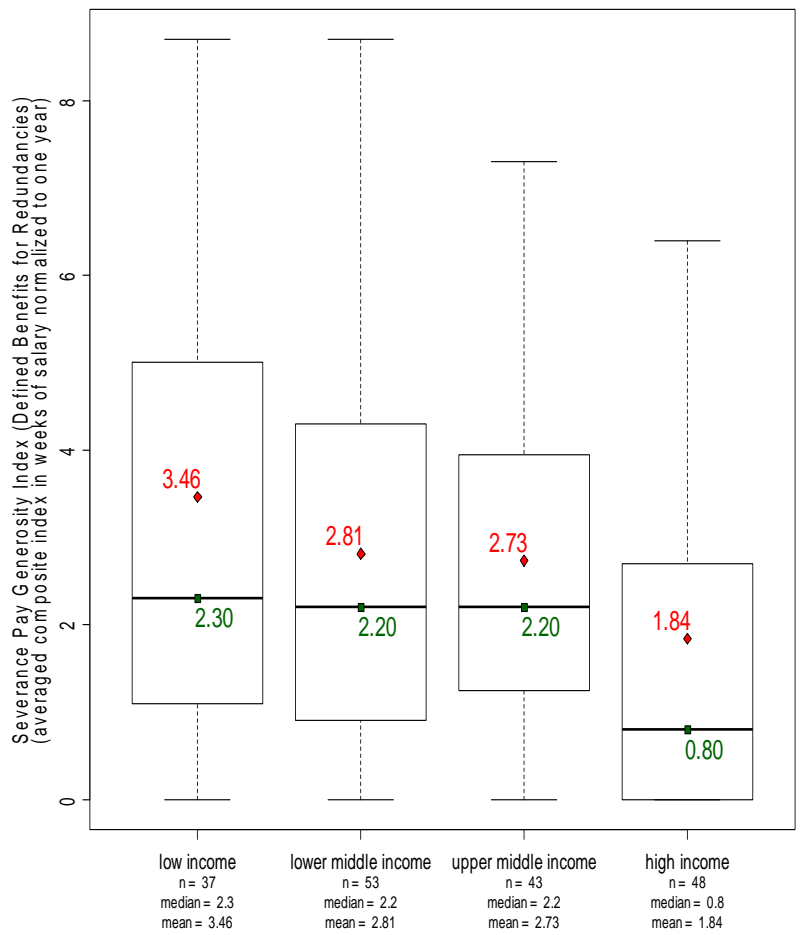

(b) by regions

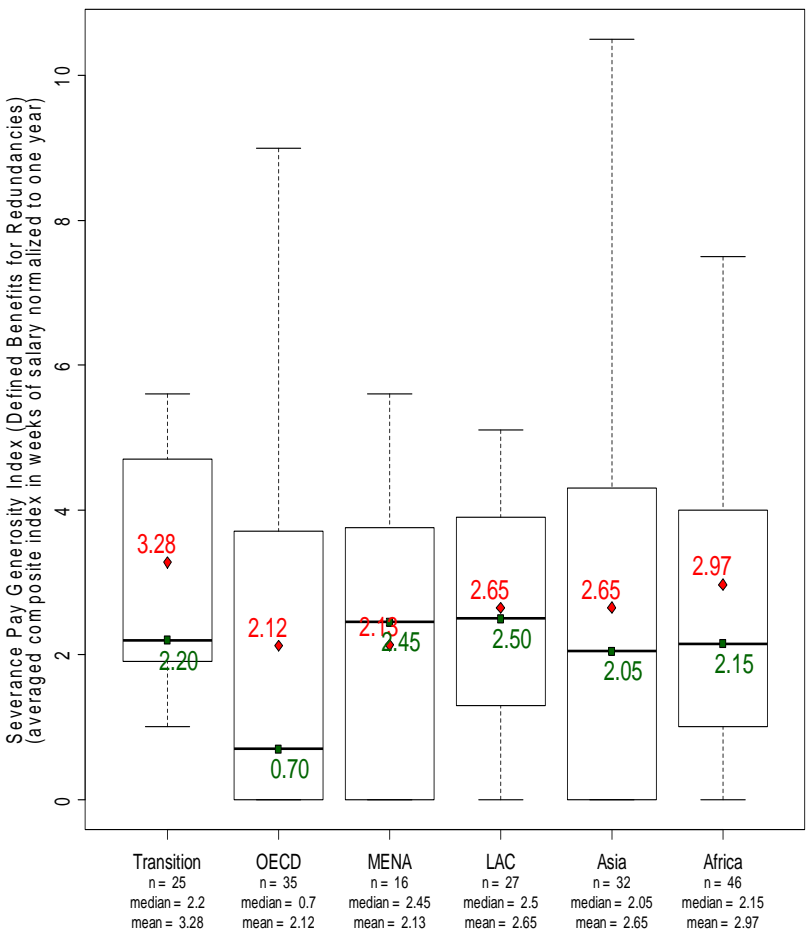

Source: Annex 2

Funding. The country review indicates that most countries rely on internal flow financing for the funding of severance pay, with only a few allowing for or requesting that book reserves be established. Cash flow financing is 100 percent in low income countries and decreases broadly with increasing income level of the countries. Book reserves are currently limited to Japan and, as an option, to South Korea among high income countries and to Poland among high-middle income countries); see Figure 3.6, panel a. In the past, firms in a few other countries and circumstances were obliged to create book reserves for future severance pay expenses (in Austria before the 2003 reform, Italy ongoing after the 2007 reform for firms with less than 50 employees, South Korea before the 2005 reform, and Venezuela with a continued option for internal and external funding), and/or reinsure their payments with insurance companies (in Chile and South Korea). A small number of countries have also set up public guarantee funds to compensate, at least partly, the severance pay claims of workers whose employers are insolvent (typically, such funds also compensate workers for unpaid wages). According to our documentation, these funds exist in Austria and Chile (for the workers under the old severance pay regime), and a number of other middle to high countries in Europe, Latin America and Asia. These countries include Colombia, Estonia, Finland, Hungary, Israel, Italy, Romania, Slovenia, South Korea, and Thailand. These guaranteed funds typically are funded by contributions by employers and organized at national level. In Italy, the end-of-service pay provisioned with firms is guaranteed by the social security fund.

External funding through individual accounts or centralized funds is limited to a small but growing number of middle to high income countries, with individual accounts concentrated in upper middle-income and a few high income countries (Figure 3.7, panel a). In these countries, firms (and sometimes workers themselves) are obliged by law to deposit severance pay 
contributions in individual savings accounts of workers. These deposits then earn interest and are paid out either as a lump-sum or in monthly payments, subject to continuing eligibility. This is the case in Brazil, Chile, Colombia, Peru, and Venezuela, and since 2003, also in Austria (on the Austrian and Chilean reforms, see next section).

In some countries, employers are required to pay contributions to a centralized fund (Northern Africa, Barbados). The contribution rates of employers (levied on gross wages) range from a low of 0.5 percent in Barbados and Morocco to about 2.5 percent in Algeria, Chile, and Egypt, to 8 percent in Colombia and Peru, and to 17 percent in Venezuela. Government discretionary support is available in many OECD and transition countries.

Figure 3.7a\&b: Funding Methods

(a) by country' income level

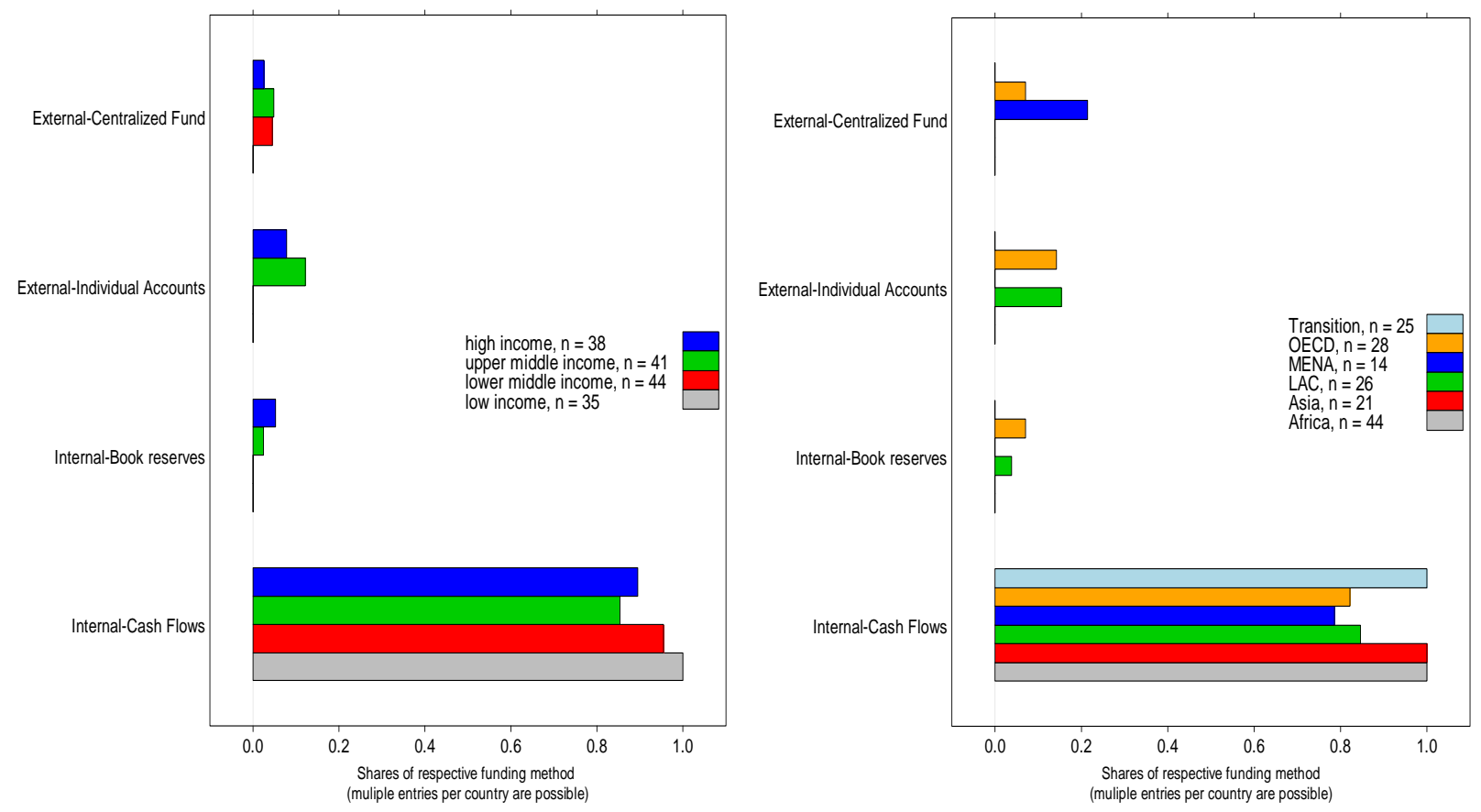

Source: Annex 2

Taxation rules. Information on taxation is difficult to collect and we obtained information on only $1 / 3$ of the applicable 152 countries. The available and perhaps unrepresentative information suggests major differences across income levels and especially across regions. Across income levels, about 50 percent of countries fully tax severance pay, almost 40 percent of lower middle income and a small share of high income countries make these benefits tax exempt (Figure 3.8, panel a). The tax treatment is quite diverse across regions. In transition economies, almost 90 percent of benefits are fully taxed while in Latin America 100 percent are partially taxed. In OECD close to 50 percent of the countries tax fully and the rest partially, while Asia and Africa, full taxation never takes place and in 50 percent of the African countries and 40 percent of the Asian countries benefits are tax exempt (as are, often, old-age income benefits). 
Figure 3.8a\&b: Taxation Rules

(a) by country' income level

(b) by regions
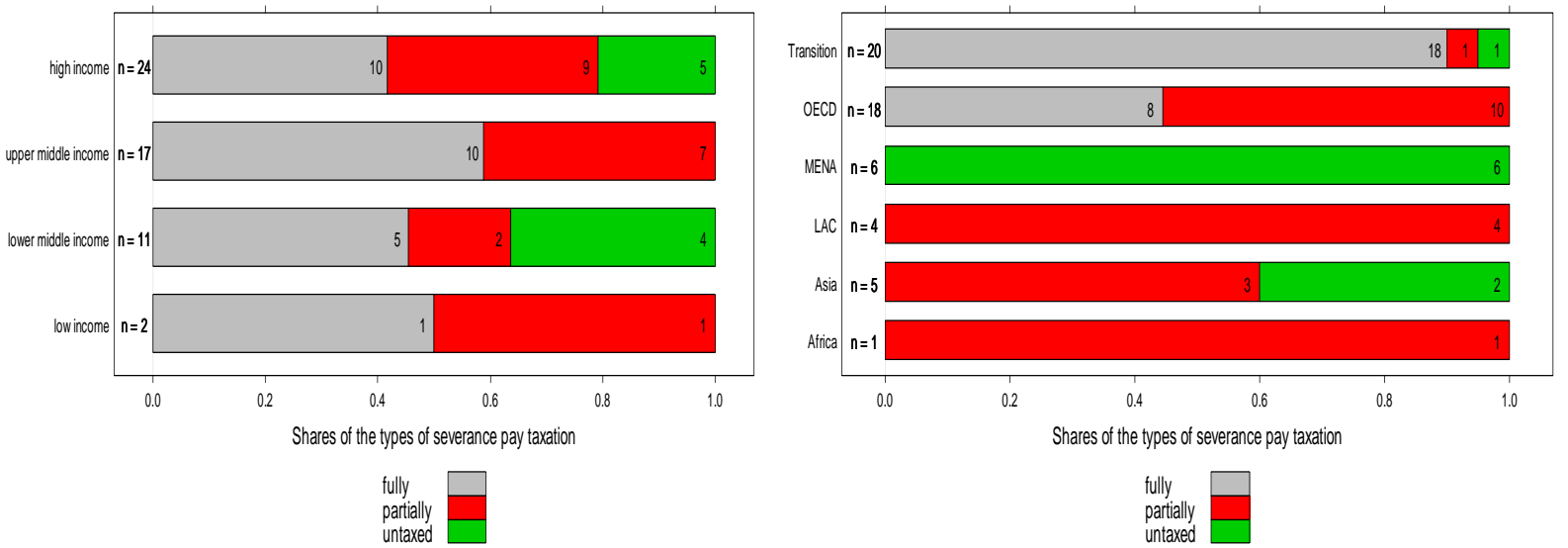

Source: Annex 2

To summarize, the above review showed that countries use widely different approaches when providing severance pay but the vast majority uses current revenues to finance severance pay expenditure. High-income/OECD countries tend to use less generous systems, require more demanding prior employment eligibility conditions, often allow any reason for separation, and rely much more on collective-agreement based systems. The inverse relation between income level of a country and severance pay generosity is very pronounced and valid at different lengths of service. In the vast majority of countries, severance pay is financed from the firm's cash flow. Few countries require firms to create book reserves and/or reinsure their payments with insurance companies, and very few have set up public guarantee funds.

The desk-review of legal provisions in this Section as well as the analysis of incidence and generosity of severance pay in Section 4.2 fall clearly short of a comprehensive investigation of the impact of severance pay in developing countries: To what extent is the mandate evaded and encourage informal employment and not income and job protection?; to what extent is the mandate reneged by partial or full non-compliance from the employer?; for the severance pay disbursed, what is the impact on poverty, labor supply, etc of the individual and household?; etc, etc. There are piecemeal indications for the relevance of all of these and other topics that must be left to future research.

\subsection{Reform directions}

For the severance pay inventory we gathered also information about recent reforms undertaken. This is to supplement latest cross country information with a sense of recent changes and emerging reform directions. In short, most countries undertook no or only minor parametric reforms since the 1990s. ${ }^{7}$ Since the early 2000 a few upper middle to high income countries have engaged in interesting and partly innovative reforms: Chile (2002 and 2008), Austria (2003), Italy (2004 and 2007), Korea (2005).

\footnotetext{
${ }^{7}$ The inventory on policy reforms profited tremendously from the input and review by a team of Tower Watson Uruguay (Maximiliano Sosa, Jessica Gerpe, Rodrigo Baudo). All errors and missed reforms, however, remain our responsibility.
} 
The Chilean reform of October 2002 introduces an innovative scheme that combines the effectiveness of risk pooling with the increased incentive neutrality of individual accounts. Under this scheme, dependent workers contribute into two funds: a fund formed by pure individual accounts and a solidarity fund. For temporary workers, the full $3 \%$ are paid by the employer; for non-temporary workers the employee pays $0.6 \%$, the employer $2.4 \%$ of which $1.6 \%$ go to the individual account and $0.8 \%$ to the solidarity fund (Acevedo, Eskenazi and Pages, 2006; Bernstein, Fajnzylber and Gana, 2011). In case of unemployment they can have access to their own savings but, under some circumstances, they can complement them with resources provided by the solidarity fund in order to finance 5 monthly payments, defined as a percentage of their previous wage. In this context, the initial use of own funds can be interpreted as a deductible for accessing the solidarity fund, therefore providing a self-policing mechanism.

The experience during its first 8 years has been positive in terms of coverage and sustainability. The accumulated experience over this period allowed the government to introduce in May 2009 a set of reforms designed to improve the adequacy of benefits by facilitating access to the pooled component. Current welfare evaluations (Bernstein, Contreras, and Benvin, 2008) suggest that, in general, most workers value positively the presence of the program, even if their valuation depend on their level of risk aversion and the type of labor history, Risk averse, older or more educated individuals will benefit more from the consumption smoothing properties, whereas Chilean women are less likely to benefit from the program, as their labor histories are more interrupted than those of men. Evaluations of the system in terms of labor incentives are currently underway (see, Bernstein, Fajnzylber and Gana, 2011). Very significantly, efficiency effects produced by this unique and innovative system indeed seem to conform to the expectations, as found by the recent study by Reyes, van Ours, and Vodopivec (2010). For beneficiaries using the solidarity fund, the pattern of job finding rates over the duration of unemployment is consistent with moral hazard effects, while for beneficiaries relying on unemployment insurance savings accounts (UISAs) only, the pattern is free of such effects. The authors also find that for benefit recipients not entitled to use the solidarity fund SF, the amount of accumulation on the UISA does not affect the exit rate from unemployment, suggesting that such individuals internalize the costs of unemployment benefits.

Overall, the new scheme seems to have been a success and has largely avoided the distortions that plague unemployment insurance systems. The 2009 reform focused on four aspects (Bernstein et al. 2011): (i) an increase in coverage of the solidarity fund observed since the implementation of the scheme; (ii) an increase in the low level of replacement rates; (iii) a change in the investment regime more in line with futures of the unemployment insurance members; and (iv) improvement in coverage of nonmonetary benefits (i.e. job search and retraining). Yet, in parallel with this scheme, Chile keeps both mandated and quasi-mandated severance pay schemes for dismissal and redundancy, with no known plans for integrating the former into the savings accounts.

For all new labor contracts and for voluntary changers, the Austrian reform of 2003 (Koman, Schuh and Weber, 2005; Hofer, Schuh and Walch, 2011) moves the traditional severance pay toward an occupational pension cum income support for those dismissed with longer tenure. The severances pay entitlements of workers who are eligible under the old program remains unchanged.

The reform of the severance pay scheme had been a topic of a controversial reform discussion for some time. Trade unions wanted an extension of entitlement to voluntary separations and 
seasonal employment. There was general view that the old severance pay program damaged labor mobility. The goal of the government was to transform the severance pay into a new occupational pension scheme which should be the second pillar (in European and World Bank count) of a multi-pillar pension scheme.

Under the new scheme which started on January $1^{\text {st }}$, 2003, coverage and entitlement is substantially increased as enrolment starts with the first day of employment. The scheme also applies to temporary workers and is not dependent on the form of contract termination. Employers have to pay a contribution 1.5377 percent of payroll into a fund, specified by an agreement between employer and worker council, and licensed by financial market authority, which handles the administration and asset management. The maximum charge by an administrator is 3.5 percent of the yearly contribution revenue.

If dismissed by the employer with tenure exceeding 3 years, the employee can choose between a lump-sum payment of the accumulated amount or continued saving toward a future pension. In case of a voluntary quit or job tenure shorter than 3 years, no lump-sum payments will be received, but the acquired claim remains and can be transferred to the fund of the new employer. This differential treatment by the type of separation (dismissal or voluntary quit) and the length of tenure (below and above 3 years) has a social benefit objective: it provides potential income support for the dismissed with long tenure, but it keeps money for future retirement for voluntary leavers and the short-term employed.

The second-pillar pension or unemployment insurance benefit dimension is also visible in the benefit payout option. If withdrawn as a lump sum payment, the (low) tax rate of 6 percent for this type of employer sponsored benefit is applied. However, if the benefit is disbursed in monthly installments (including annuities bought at retirement), no tax will be levied.

Simulations based on administrative individual records for the period 1984-2001 suggest that the new rules are less generous, and that the contribution rate may be too low to generate significant benefits (Koman et al, 2005). Experience since reform also suggests that frequent withdrawals of funds after job termination substantially reduces potential funds for retirement income (Hofer et al., 2011). This phenomenon has been accentuated (or perhaps motivated) by the low level of remuneration achieved by the funds. The latter is claimed to be linked to the capital guarantees the funds need to provide. Econometric investigations suggest that the new scheme changes little the job mobility or, put differently, the old scheme may have had little detrimental effect.

Overall, the performance of the new scheme has been modest. This may be due to design issues of the new scheme (withdraw rules, capital guarantee, low contribution rate) but may also reflect limited improvements in incentives over the prior scheme. The discussion about a further reform has been side tracked by the recent crisis.

The Italian severance pay system (2004 and 2007 reforms) has a number of particularities; some claim that severance pay as conventionally understood actually does not exist (e.g. Garibaldi and Pacelli, 2004). In effect there are 2 schemes that do not fall not squarely under severance pay as known in other countries. The first scheme (tutela obbligatoria) provides a dismissal compensation for unfair termination and distinguishes between firms (actually establishments): small firms with 15 and less employees, and larger firms with 16 and more. Once a court rules that a worker is unfairly dismissed, smaller firms have to pay 2.5 to 6 months of wage as compensation. Larger firms have to reinstate the employee who can, however, select 15 months 
wage compensation. The economic interpretation of severance pay emerges as courts reportedly often judge in favor of the employee.

The second severance pay is an end-of-service pay (Tratamento de Fine Rapporte, TFR) that is available upon separation from the firm or before if they have tenure of at least 8 years or if the employer agrees. This can be used for health related expenditure, buying a house, or for specific periods of unpaid leave. For each year of service, a provision of two twenty-seventh (or 1/13.5) of the gross yearly wage is included in the individual TFR account with the firm and revalued yearly with a factor of $1.5 \%$ fixed plus $75 \%$ of the CPI inflation of the previous year. In effect, the employee provides a loan to the firm that he can use for selective events before separation, after separation and perhaps unemployment or eventual retirement.

Public policy changes over the last decade have been geared toward strengthening the retirement component with pension reforms that have and will reduce benefit levels under the public scheme in the background. To this end, in 2004 the government provided an option to enroll into a supplementary pension scheme in return to giving up their TFR for new labor market entrants and also older workers were encouraged to enroll. While such a selection cannot be reversed, those workers staying with the old system can reconsider their choice at any moment. To support such a choice and strengthen supplementary pensions the law of 2004 made a number of radical innovations (Casare et al, 2008): making the participation the default option for severance pay; favorable taxation of benefits whether paid as lump sum or annuity, and changes in contribution, benefit, advances, redemption and portability. By 2007, the Italian government decided that companies with 50 and more employees must shift the new flow of severance pay contributions to itself and the government will pay the benefits directly no matter the decision by the employee (Corsini et al, 2010).

So far fiscal and other incentives have had limited effects. By the end 2008 only 26 percent of eligible workers had signed-up for the supplementary pension scheme. The explanations range from temporary effects due to the financial crisis to systemic ones, including the credibility of supplementary schemes and liquidity preferences by workers. A number of economists are worried about the liquidity and broader economic effects for small and medium sized enterprises as they are losing access to cheap internal financing (Calcagno et al. 2007).

The Korean severance pay reform of 2005 initiated a voluntary conversion of an end-of-service pay scheme into an occupational pension system with the objective of replacing an unfunded scheme that pays lump-sum benefits with a funded system that provides an annuity after retirement (Yun and Hur, 2011). The original severance pay scheme, introduced in 1953 and made mandatory in 1961, had the objective of income support for both the unemployed and retirees at a time when neither an unemployment benefit nor a pension system existed. A mandated defined benefit pension plan was introduced in 1988 and an unemployment insurance system in 1995. The generosity of the pension scheme was reduced after the financial crisis of 1997-1998 when it became clear that the system will not be sustainable despite the increasing reserves due to incomplete system maturation. The first old-age pension benefits were paid in 2008.

With the 2005 reform, employees and employers could either continue their severance pay scheme by mutual consensus or start a corporate pension system (defined contribution or defined benefit). Under the corporate pension system, employees forgo withdrawing benefits before separation (as allowed under severance pay scheme) except for a housing purchase or long-term 
care. Furthermore, the rate of return is dependent on the performance of financial institutions with which the pension scheme is established (e.g. asset management companies, insurance companies and banks); under the severance pay scheme the implicit rate of return is the individual wage growth.

The take-up of the new scheme is considered disappointingly low. As of November 2010, about 2 million out of 7.7 million eligible workers have joined the corporate pension scheme, i.e. some 26 percent. In order to motivate a stronger conversion toward corporate pensions, the corporate tax act was reformed at the beginning of 2011 and the tax deductibility of the employer's contributions was limited to external funding. Before employers enjoyed tax privileges when reserving for severance pay commitments with book reserves.

In summary, the reform examples of Chile, Austria, Italy and Korea have a number of commonalities:

- All countries have unemployment schemes that provide income support for the dismissed and comprehensive pension schemes whose generosity is scheduled to fall. This reduces the need for severance pay as consumption smoothing device for the unemployed while offering the opportunity to use the resources for strengthening supplementary pension pillar. This was part of the reform consideration behind their reforms.

- The willingness by individuals to forgo access to liquidity during working life is seemingly limited as inferred by the limited roll-over in Austria and funded scheme selection in Italy and Korea. This liquidity preference is likely to be influenced by the low rates of return offered by the funded provisions which may reflect the recent financial crisis, the status of their financial market development, and the continued dominance by the banking system.

- Labor market considerations had a limited role in the reform motivation, as the effect in any case is likely to have been small (Austria) or non-existing (Italy). Labor market considerations seem to have been absent for the Korean reform.

Let us conclude this chapter with a comment on the political economy of severance pay reforms. Reducing job protection for formal sector workers is politically difficult, to say the least, and often meets with stiff resistance from 'insiders' because it increases the prospects of layoffs and dismissals from previously protected jobs. Yet many countries have taken this difficult step (for example, transition countries of Central and Eastern Europe). The introduction of well designed, cost-effective active and passive labor market programs that provide more efficient protection to workers in the long run (in lieu of protection of jobs) and that help allaying the short term political costs of reforms has proved instrumental in achieving this policy shift. ${ }^{8}$ But the necessary and sufficient ingredients for such change are far from being well-known: for example, despite continual efforts of employers, Sri Lanka's severance pay - one of the most restrictive severance pay systems in the world, see above - has not reduced its generosity and procedural

${ }^{8}$ During the early transition of Eastern European countries, reductions in job protection were accompanied by the active and passive programs to ease restructuring/layoffs. While the programs were initially generous and increased fiscal costs, their generosity was significantly reduced over time, as the goals of the restructuring agenda were met, though reducing entitlements was difficult (see Vodopivec, Wörgötter and Raju 2005) 
complexity, and in fact, several changes in the last decade have, if anything, even increased its generosity (see Box 3.2).

\section{Box 3.2: Political economy complexities of reforming several pay program}

Sri Lanka's strict severance pay regulations (embodied in the Termination of Employment of Workmen Act No. 45 of 1971) were enacted at a time when Sri Lanka was pursuing inwardlooking economic policies, characterized by an import-substitution industrialization policy, stringent exchange controls, price controls of many commodities, and a program of nationalization of a wide-range of establishments. The TEWA was intended to arrest the rising rate of unemployment which resulted from these policies, as many industries could not operate in the restrictive environment and had to reduce or retrench workers. Moving the second reading of the TEWA Bill in the legislature, the then Minister of Labour explained that “.... the intention in creating this law is not to put employers into difficulty, but solely, to prevent the loss of employment of workers for unreasonable or frivolous reasons. Where employers who face justifiable difficulties - for example, the shortage of raw materials - and need to terminate the services of workers, the Commissioner of Labour has an opportunity to intervene and, after discussing with other departments and Ministries, and take some remedial action relevant to both employer and workers to prevent the reduction in the strength of the organization or of the workforce.”

The intention of the TEWA was clearly to prevent or discourage mass retrenchment situations, rather than individual terminations. However, the statute as enacted did not carry such a limitation, and terminations other than those intended initially are even now covered under the TEWA. Both the fact that the generosity at the introduction was increased above the intention of the government, as well as the persistence of the generosity of the program despite several changes of the TEWA act, witness the political economy complexities of changing regulations that benefit only the minority of workers (about two thirds of Sri Lanka's workforce works in the informal sector) given the presence of strong, well organized trade unions.

Sources: Ranaraja (2006) 


\section{The Motivation behind Severance Pay: Reviewing Hypothesis and Evidence}

The purpose of this section is to examine severance pay programs as part of a broader institutional framework, thereby also stimulating further research. To this end this section starts out with proposals for the economic rationale of severance pay, after which some simple crosscountry regressions are reported using our data inventory. As the data do not allow for testing the efficiency effects of severance pay, the section closes with a brief and selective review of the empirical literature.

\subsection{The Economic Rationale of Severance Pay}

The few papers about the origins of severance pay and the still limited but rising theoretical and empirical literature on this topic suggest three main hypotheses about the economic rationale of severance payments. First, severance payments are a primitive form of social benefits which predate or complement existing benefits for unemployment and retirement. Second, severance payments are designed to be an efficiency enhancing human resource instrument, be it as an ad hoc support to large-scale enterprise restructuring or a more permanent device tightening existing bonds between workers and firms, in order to reduce the transaction costs and the loss of firmspecific knowledge and skills due to turnover. Lastly, while severance payments may have these income protection and/or efficiency objectives, they also function as a job protection instrument, a function that gained importance over time and a life of its own.

The three hypotheses are not mutually exclusive and may apply concurrently. In some instances, the severance pay mandate is surely focused on one objective. In other instances, programs may cater to multiple objectives. Only in-depth case studies and more advanced empirical studies are likely to disentangle these multiple motives. We hope that these preliminary econometric efforts provide a motivation for further efforts.

\section{(i) Severance payment as a primitive social benefit program}

As described above, severance pay came into existence in the absence of other forms of social safety nets as an employer-sponsored benefit program providing compensation for (unfair) dismissals. At the very beginning, employers have simply paid severance pay to compensate workers for not respecting the customary advance dismissal notice. Later, and during periods of large scale restructuring, additional cash compensation was added to provide an employer financed safety net (as public systems were minimal or did not exist). In some cases (e.g. UK), voluntary severance benefits have been provided to "top-up" low, flat rate unemployment insurance/assistance benefits. In many countries mandated or quasi-mandated severance payments pre-dated public old-age retirement provisions as they were paid to individuals at a certain advanced age and made independent of the employer's actions.

This obvious link between severance pay and social benefits emerges both in policy discussion as well as in theoretical models and empirical analyses. As noted above, at the policy level, the provision of severance pay was "subject to this obligation coming to an end on the promulgation of legislation concerning social insurance (Costa Rica) or to the replacement of compensation by benefits from a welfare fund" (Dominican Republic, Egypt, Lebanon, Syria; see Herz (1954: 319). This speaks in favor of a substitution of severance pay by social benefit programs covering similar risks, i.e. unemployment and old-age. If no substitution takes place - that is severance payments are not reduced or phased-out once unemployment and old-age benefits are introduced

- then one needs to look into other explanations, including political power exerted by trade 
unions, or differences in the instruments as they correspond to different risks or needs. For example Pissarides (2001) shows that the introduction of severance payments may provide insurance against income risk when moral hazard or other frictions prevent unemployment insurance from providing sufficient coverage. In such circumstances, severance pay could provide perfect insurance against the uncertainty of job protection.

\section{(ii) Severance pay as efficiency enhancing human resource instrument}

A second set of explanations for the existence of severance payments sees them as instruments for managing human resources in an enterprise. In a short-term perspective, severance pay reacts to the need for enterprise restructuring by providing compensation that make (mass) dismissals socially and politically more palatable. According to the historic evidence, such considerations were clearly present at the time of main technological changes since the late $19^{\text {th }}$ century and they continue to today. Under such circumstances, severance pay programs are motivated by human resources management concerns such as preserving morale of remaining workers and avoiding potential damage caused by departing workers if they are not appropriately compensated.

Under the human resource rationale, severance pay becomes an efficiency wage instrument keeping workers within the firm and nurturing productive worker relationship, for example by avoiding losses of firm-specific knowledge and skills and the transaction costs associated with frequent hiring (Lazear 1990). By withholding part of the wage from the employee till he or she retires (or is fired), enterprises want to make sure that individuals with valuable firm-specific knowledge and skills are less likely to quit or to sell their transferable human capital to a competing firm. In a similar direction, severance pay may provide incentives for employed workers to invest in firm specific human capital or contribute more in the work place. In particular, longer-lasting employment is conducive to instilling trust, cooperation, and loyalty between the employer and workers. It also encourages team spirit among workers, which may contribute to higher productive efficiency and reduce the resistance of workers to the introduction of new technologies (OECD, 1999).

Suedekum and Ruehman (2003) demonstrate that two opposing forces may be at work: On the one hand the positive incentive effects due to job protection, and on the other hand the lethargy effect of the potential firing does not contain the same strong penalty (unless those dismissed "for cause" are ineligible for benefits). Alvarez and Verarcierto (2001) show in a model with contractual and reallocation frictions that the introduction of severance payments may result in Pareto-improvement.

\section{(iii) Severance pay as employment protection device}

While the first two rationales for severance pay - social benefits and human resource instrument - suggest positive returns to this instrument, they are not well researched or empirically validated. This contrasts with the notion of severance pay as job protection, which carries a negative connotation with economists (but is a worthy objective to many others). The theoretical impact of employment protection on labor market outcomes and efficiency is ambiguous. This is echoed in the ambiguous and often puzzling empirical results (see Boeri, 1999, and Addison and Teixeira, 2000 and 2004, see also section 4.2 below).

Severance pay as employment protection (not income protection) arises from the additional costs of separation that mandated severance brings to job separations. Firing costs emerge from the 
mandated benefits, the permitted causes (say on personal and economic grounds), and ruling by the courts on what is fair dismissal.

Under such a rationale, mandated termination (or end-of-service) payments that are due regardless of the reasons of separation and thus do not contribute to job protection, should not be considered under the umbrella of severance pay. Such programs are retained earnings which belong to the employee and are thus a credit from the employee to the enterprise. Garibaldi and Pacelli (2004), however, demonstrate based on the Italian case and in a small partial equilibrium dynamic model that some of the labor market effects of such termination payments are fully comparable to those of a firing tax or a severance pay with wage rigidity.

How are the three postulated economic rationales for severance pay borne out by empirical facts? Below we shed light on this question, both by providing econometric results based on basic but widely accepted specifications and by reviewing the empirical findings in the literature. In our econometric investigation we focus primarily on the first hypothesis - severance pay as a social benefit payment - by examining factors behind the incidence and generosity of the severance pay. Human resource features of severance pay are more likely to emerge from collective and voluntary provisions on which we have little information. The job protection interpretation of the severance pay has been extensively researched by others, so we provide a brief summary of their findings.

\subsection{Determinants of the Incidence and Generosity of Severance Pay}

The empirical strategy is as follows. We seek to identify the determinants of the incidence and generosity of existing severance pay programs so as to check to what extent these determinants are consistent with the above hypotheses about the economic rationales for severance pay. Among the explanatory variables we include logarithm of per capita income; the generosity of unemployment benefits and pensions; the length of the notice period; and union density. For generosity we use the severance pay generosity index presented in Section 3.2 that measures the weeks per year of service for an average of 1, 5 and 10 years of tenure.

The rationale for including the per capita income variable is as follows. According to the “development theory" (for an interpretation, see Botero et al, 2002), rich countries impose more regulations (including the regulation of job protection) than poor countries because in rich countries the benefits of such regulations (fulfillment of social objectives, for example) exceed the costs. In contrast, poor countries simply cannot afford the administrative costs nor the distortions associated with such regulations. Hence there should be a positive correlation between the level of development and the incidence (and generosity) of severance pay. An important modification of this link arises once we take into account that the emergence of social and private insurance - the emergence which is itself associated with the level of development works against the likelihood and generosity of formal severance pay programs. The above reasoning suggests an inverse U-shape relationship between per capita income and both the incidence and generosity of formal severance pay programs. Note that the above explanation supports, or is at least consistent with, the social benefit and the job protection hypothesis about severance pay.

The above reasoning thus predicts the inverse U-shape relationship between the per capita income and both the incidence and generosity of formal severance pay programs. In theory, an ideal plot with the severance pay generosity on the $y$-axis and the (log) per capita GDP on the x- 
axis, would therefore show an upward slope for countries in the lower income group, which then slowly flattens for countries in the middle income category, and finally turns into a downward slope for high income countries.

The empirical evidence is broadly but not fully consistent with this assumption with one exception. Bivariate associations between severance pay generosity index and (log) per capita GDP, shown by trend lines for each income group, suggest a positive association for both, low and upper middle income countries, and a negative one for lower-middle and high income countries. Figure 4.1 presents the data and estimations with (a, left panel) and without (b, right panel) those countries that have zero generosity values, i.e. non-mandated countries. The robust linear regression line for all countries has a negative slope for both data sets with a steeper and significant descent for the full data set. ${ }^{9}$ The negative slope is also consistent with Figure 3.6. Overall, data and estimations give some support to a mild inverse U-shaped relationship that is evident for the low and high income countries, and equivocal for the middle income countries. Figure $4.1 \mathrm{a} \& \mathrm{~b}^{*}$ presents an estimation based on a polynomial structure of the per-capita GDP variable (including all countries, not separately by income groupings).

Figure 4.1a\&b: Generosity of Severance Pay and per-Capita GDP

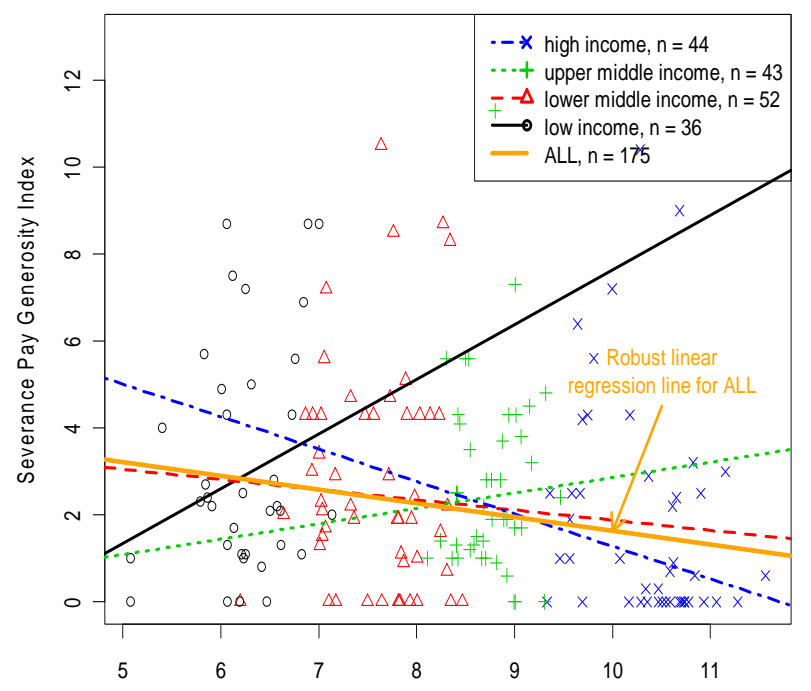

log. GDP per capita (Current US\$, 2009)

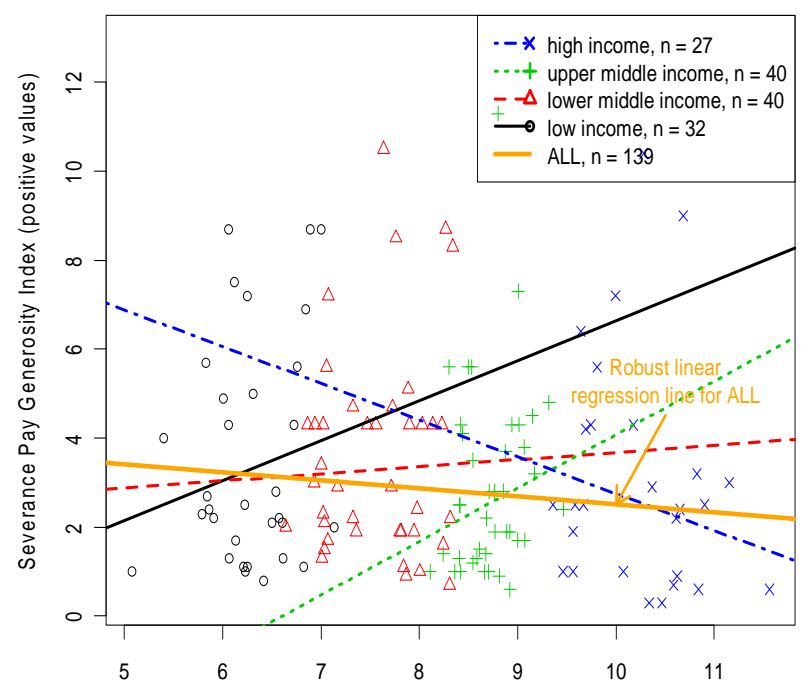

log. GDP per capita (Current US\$, 2009)

Source: Own computations based on data presented in Annex 2.

\footnotetext{
${ }^{9}$ The robust estimation excludes extreme values. For details on the estimation and statistical criteria, see Annex 3.
} 
Figure 4.1a\&b*: Generosity of Severance Pay and per-Capita GDP
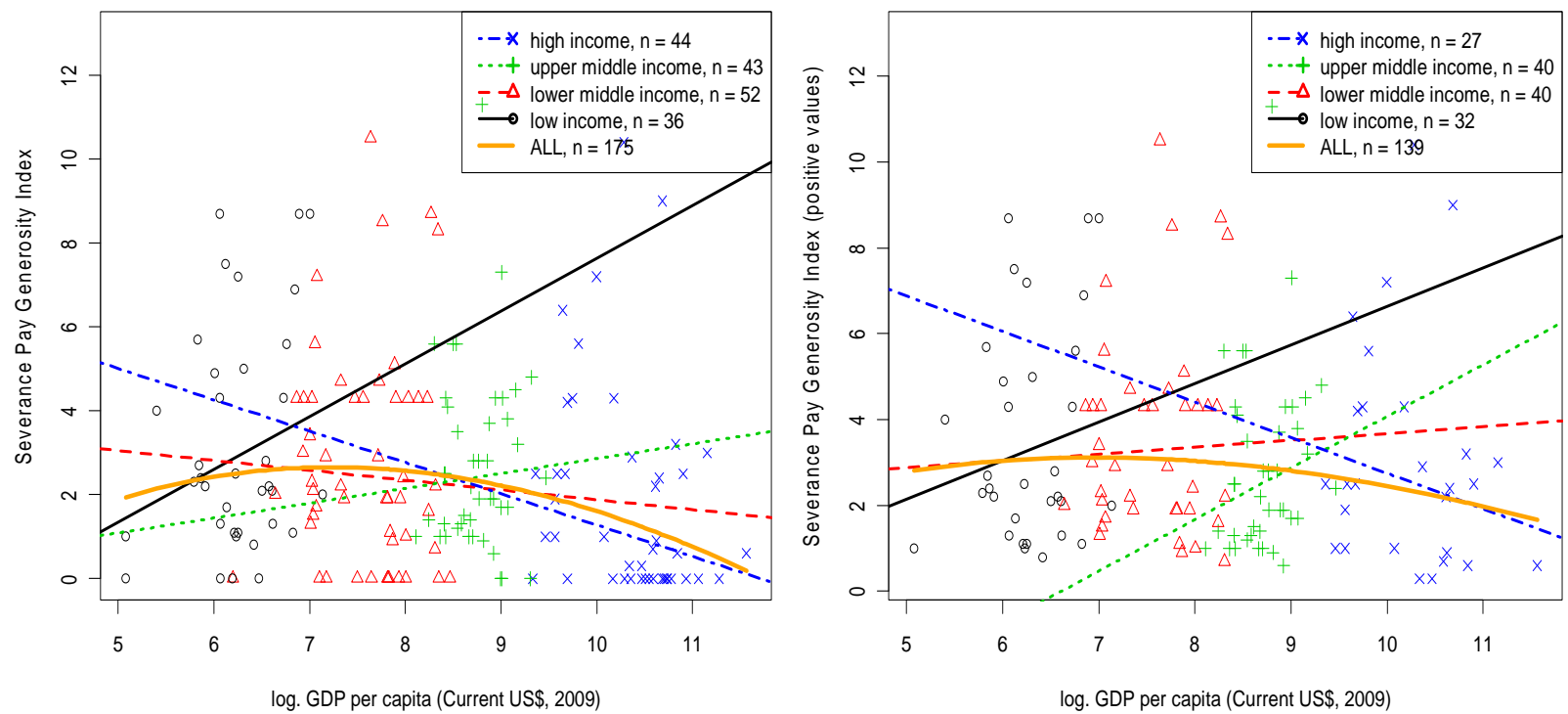

Source: Own computations based on data presented in Annex 2.

Before testing the relationship of severance pay and other social benefits, notice period, and union density, we want to explore the relationship of these other social policy and labor market instruments to the income level of the countries. For the latter we use again the per-capita GDP (in logs). Figures 4.2 to 4.4 present these relationships. For the generosity index of unemployment benefits we use the available replacement rates for the average income worker; for the pension benefits the prospective replacement rate of the average income worker as calculated by the OECD APEX model are used. In the benefit case we have two figures each: The left panel that includes zero generosity in the case when benefit programs do not exist, and the right panel with positive benefit levels only. The notice period is the average number of weeks for workers with 1, 5 and 10 years of service from Doing Business 2011.

Figures 4.2 and 4.3 signal contrasting relationships of generosity and income level, depending on the inclusion or exclusion of zero values (i.e. the absence of such a mandated program). And the contrasts differ between unemployment and pension benefits. Figure 4.2 plots the relationship between the generosity of unemployment benefit systems and income level with and without zero values for unemployment benefit generosity (which indicates the absence of a mandated program) for those countries that provide the information. The figure on the left panel of Figure 4.2 already suggests a significant positive relationship with the income level of countries if the zero values are included. Once only positive values are considered, this positive relationship becomes even stronger (Figure 4.2, right panel) when looking at all data points or only the high income group. The following applies to pension benefits: Strongly positive relationship if also zero values are included; mildly negative relationship in case only positive generosity values are considered.

The interpretation is not straight forward but in any case suggests important differences between unemployment and pension benefit generosity. Unemployment benefits are clearly less widespread and zero generosity reaches into higher income countries. Once countries provide unemployment benefits there is a significant positive relationship of generosity and income level of a country that may be linked to decreasing informality, better job matching objectives or redistributive considerations. 
Figure 4.2a\&b: Unemployment Benefit Generosity and per-Capita GDP
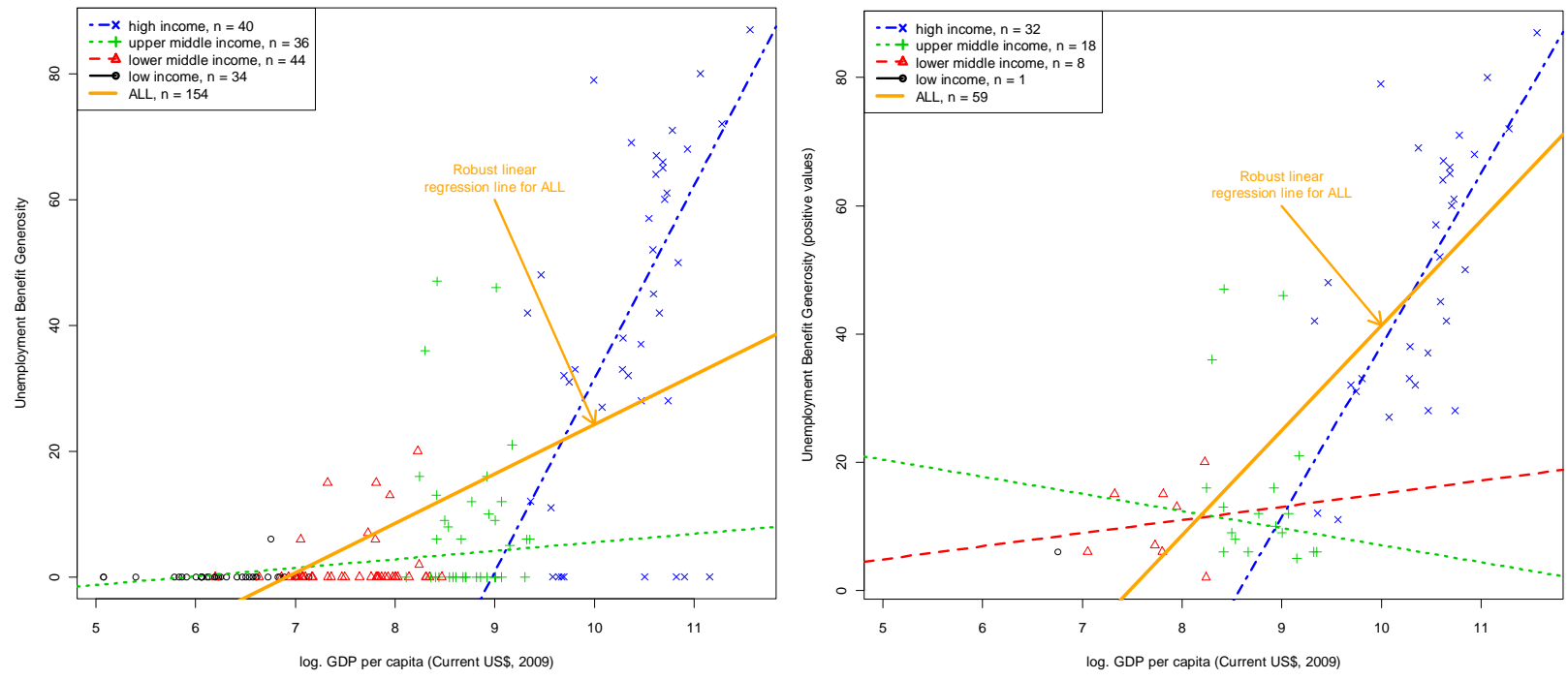

Source: Own computations based on data presented in Annex 2.

Pension benefits programs are much more wide-spread even if the coverage of the population itself is strongly correlated with the income level (see World Bank, 2011) ${ }^{10}$. As a result there are few upper and only one high income country (Equatorial Guinea) without benefit scheme giving rise to the positive slope when all countries for which information is available are considered (left panel). Once only positive generosity values are considered (right panel), there is a mildly negative yet statistically insignificant relationship with income level, which may be related to the level of financial market development and the capacity to substitute mandated (and often unfunded) pension schemes with voluntary and funded provisions as income level increases.

Figure 4.3a\&b: Pension Benefit Generosity and per-Capita GDP
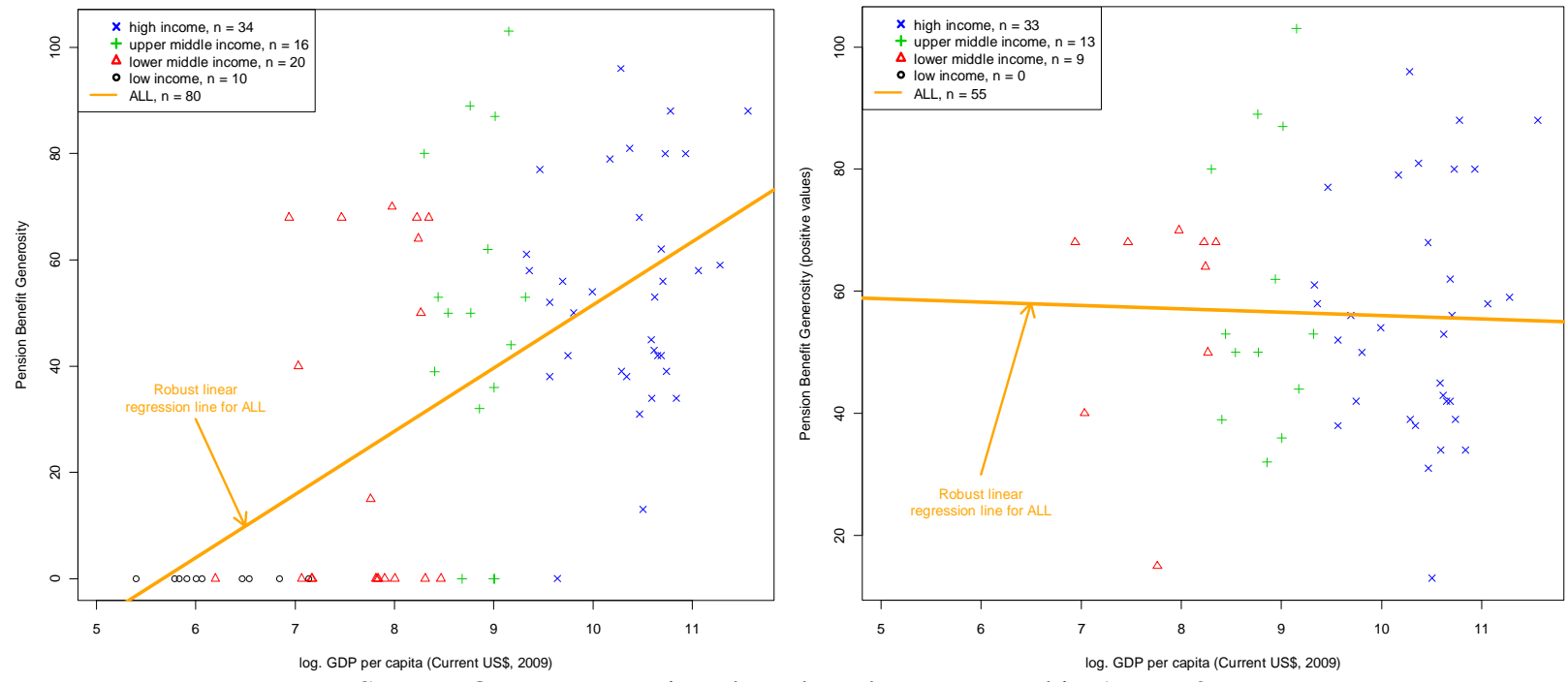

Source: Own computations based on data presented in Annex 2.

10 Selected data are available as retrievable spreadsheets in the World Bank's Social Protection Web-site at http://www.worldbank.org/pensions. 
The notice period for dismissals exhibits a positive slope for high and upper middle income groups (Figure 4.4). For low and lower middle income groups as well as for the overall robust estimation the slope is close to 0 , implying no relationship between income and notice period in these groups. This is somewhat surprising as lower income countries are often conjectured to have more rigid employment protection laws. The positive relationship with the income level for higher income economies makes the notice period consistent with efficiency and/or redistributive considerations.

Figure 4.4: Notice Period (in weeks) and per-Capita GDP

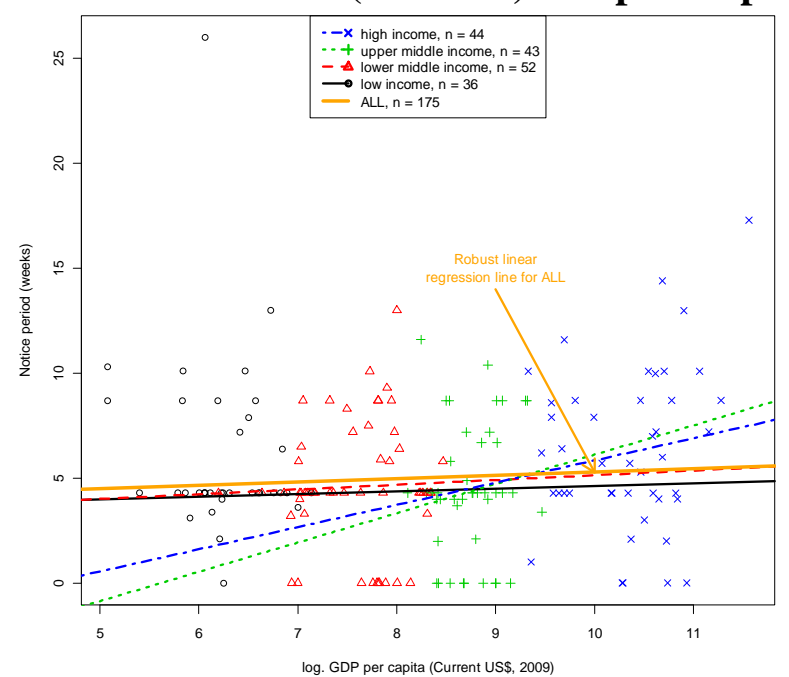

Source: Own computations based on data presented in Annex 2.

To explore the social benefit hypothesis more directly, we examine how the generosity of other cash benefit systems - in particular, unemployment benefits and pensions - affects the generosity of severance pay. Assuming that other cash benefit systems are substitutes for severance pay, introduction of unemployment insurance benefits or the increase of their generosity may lead to a reduction of severance pay benefits, thus yielding a negative association between the generosity of the two benefit systems (similarly for pensions). Because we do not have historic data, we cannot investigate how the introduction of unemployment benefit systems has affected the generosity of severance pay.

Figure 4.5 displays the interactions for the generosity index for severance pay and unemployment benefit systems. The regression lines for each income level suggest positive associations for the lower and upper middle groups and a negative one for the high income group if all countries (including those with zero generosity) are included. The robust linear estimation across all countries exhibits a significant negative coefficient (Figure 4.5 left panel). The coefficients for each income level are significant as well. If only positive values for benefit generosity are considered, the coefficient for high income countries turns zero while the overall relationship remains slightly negative. However, for all these models only the intercept remains statistically significant. 
Figure 4.5a\&b: Generosity of severance pay vs. unemployment benefit generosity
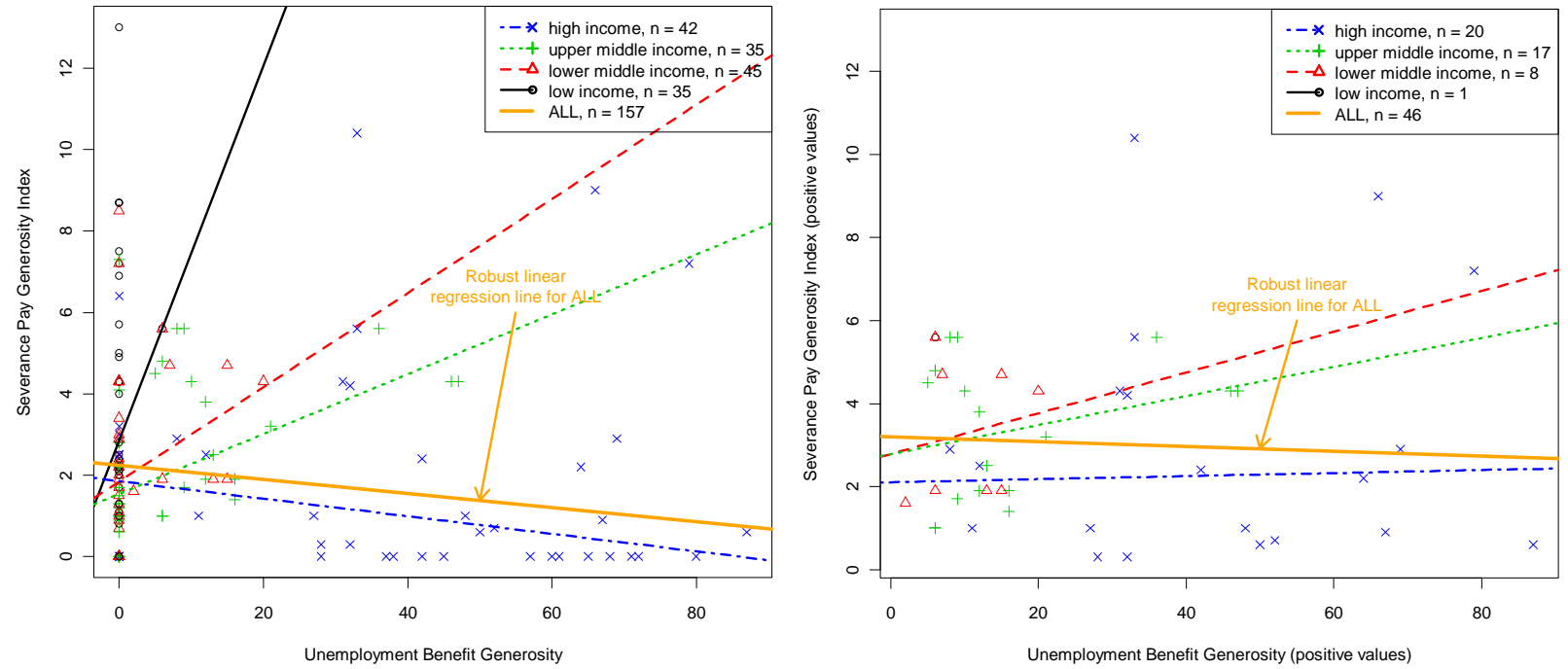

Source: Own computations based on data presented in Annex 2.

The correlation between the generosity of severance pay and unemployment benefit is positive for low income groupings, with rising income level, the correlation becomes less positive. It ultimately turns significantly negative for high income countries as well as for all countries (in case when countries with zero generosity are included). This is also due to zero (mandated) values in high income economies that all offer severance pay via collective agreements. We can thus conclude that if there is complementarity between both benefits, the strength of this relationship is definitely decreasing with income level and it is turning, apparently, into substitutability for higher income countries. The latter seems to imply a shift from a mandated severance pay program to severance pay arrangements based on collective agreements.

A possible overall complementarity of severance pay and unemployment benefits is consistent with the results of Parsons (2005a, b, c). Based both on theoretical modeling and empirical analysis of the U.S., he also found that severance pay and unemployment insurance are complements. Moreover, Parsons (2005a) noted that a study of private severance pay before and after the introduction of public unemployment benefits in the 1930s found no evidence of crowding out of private severance by public unemployment insurance.

Figure 4.6a\&b suggests that the relationship between the generosity of severance pay and pension benefit is weakly positive for all considered country income groups (except for lower middle income countries that have, however, a small sample size). As with data for the generosity of unemployment benefits, we use replacement rates for average income earner to measure the generosity of pension benefit. The resulting broadly positive associations of severance pay and pension benefits are more in line with complementarity between social benefits and severance pay generosity across countries. 
Figure 4.6a\&b: Generosity of severance pay vs. pension benefit generosity

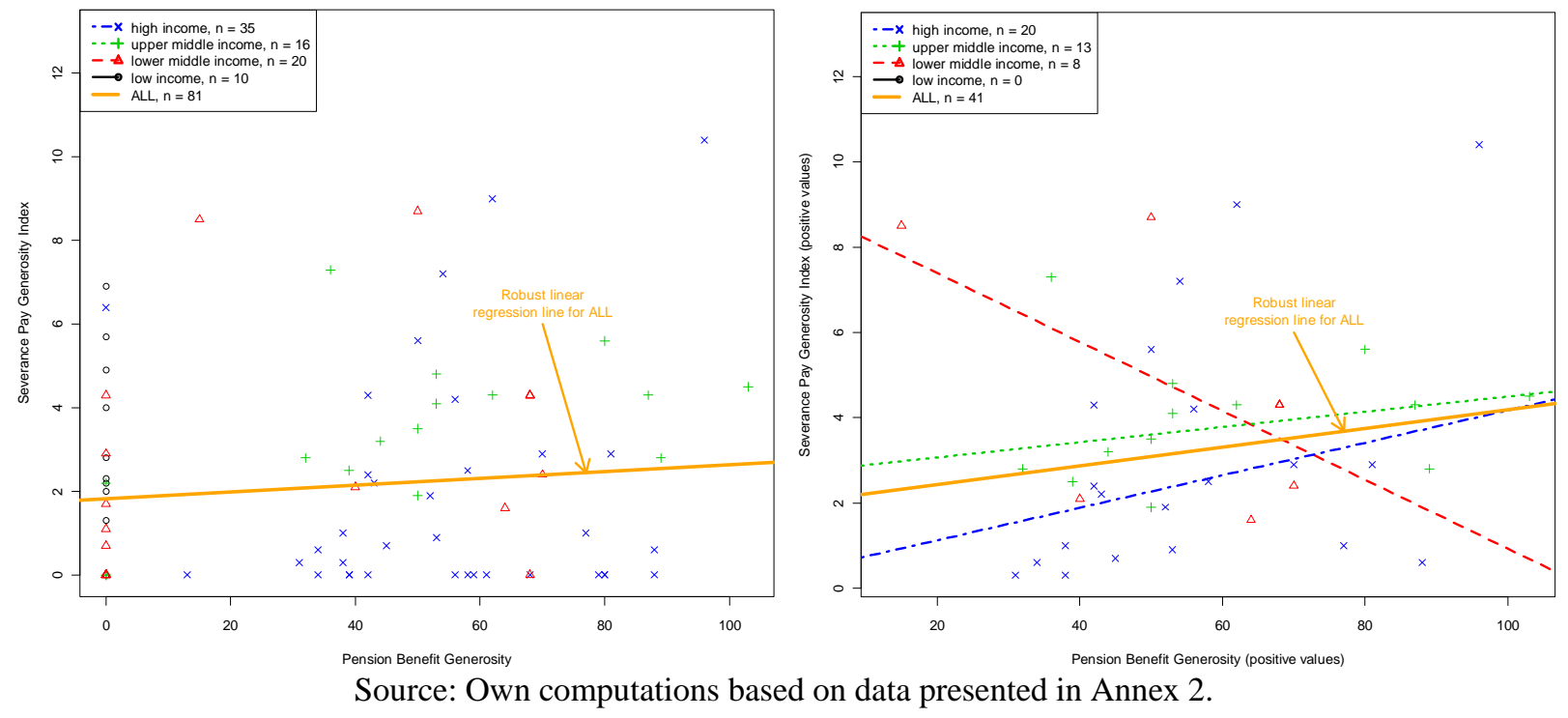

In Figure 4.7a\&b we present the association of severance pay generosity and notice period, for all countries (left panel) and for those with positive values only (right panel). Again there are main differences between the samples and within the samples. If all 181 countries are considered, the robust estimation signals a significant negative association and hence substitutability between severance pay generosity and notice period. For the sub-groups, however, the graph and related estimates signal a change with income level: A high level of substitutability for low income countries that turns into mild complementarity for high income countries, with middle income countries again providing mixed signals. If only positive values (126 countries) are considered, the complementarity aspect dominates except for the high income group where we find signs of a mild substitutability. As in the prior cases of all or positive values only, there are interesting signals of regime change between the presence and absence of benefit programs and regulations that require further investigations.

Figure 4.7 Severance Pay Generosity and Notice Period
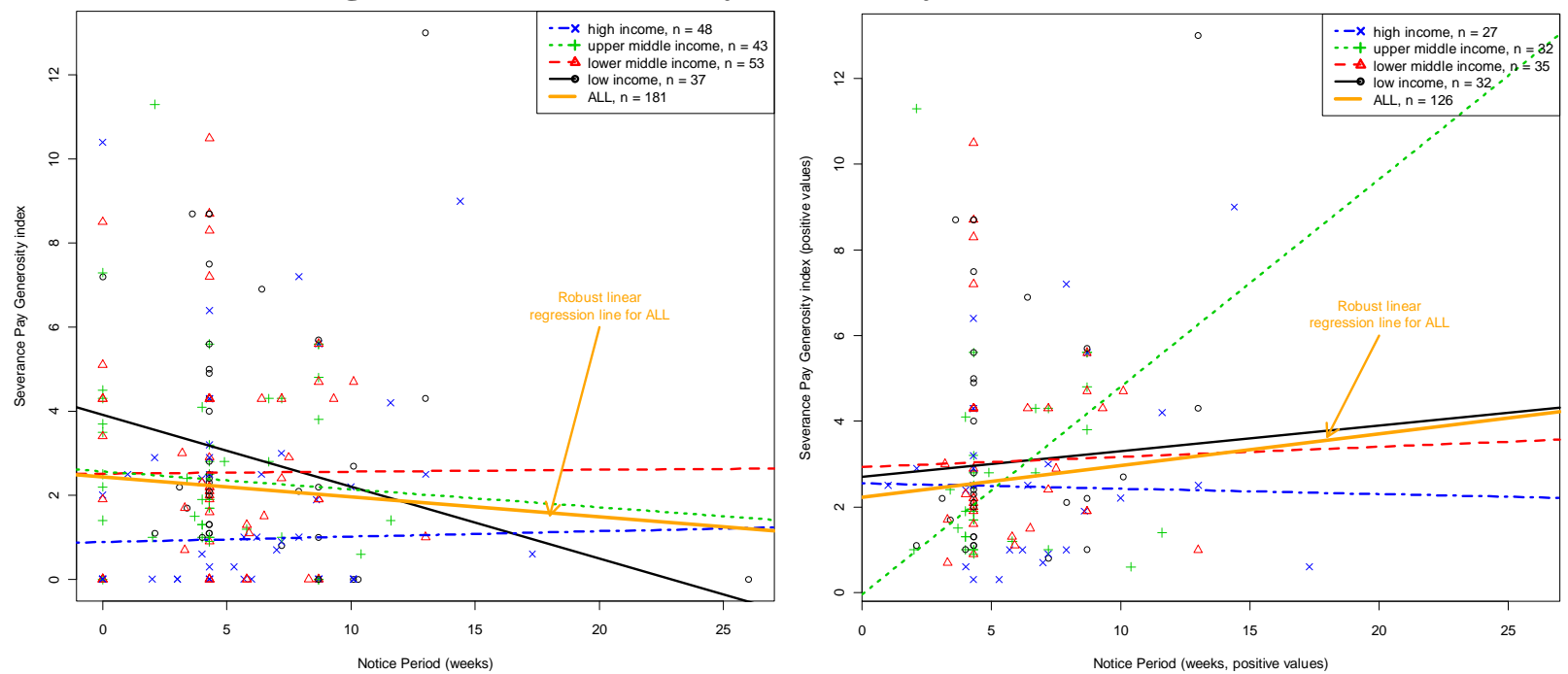

Source: Own computations based on data presented in Annex 2. 
The inclusion of union density among the explanatory variables allows us to test whether the influence of trade unions (as proxied by union coverage) translates into more generous severance pay. Note that a positive link between union density and severance pay is consistent with both the social benefit and the job protection hypotheses. Bivariate associations between severance pay index and union density, shown by trend lines for each income group, suggest negative association for low, upper-middle, and high-income countries, and positive association for lowermiddle income countries if all countries are considered (Figure 4.8, left panel). This would be largely in contrast to political power theory. However, if only positive generosity values are considered then a positive link emerges for all but the low-middle income grouping. This may suggest that once a program is established, then unions seem to be able to exert a positive impact on generosity that is linked with union density.

Figure 4.8: Severance Pay Generosity and Union Density
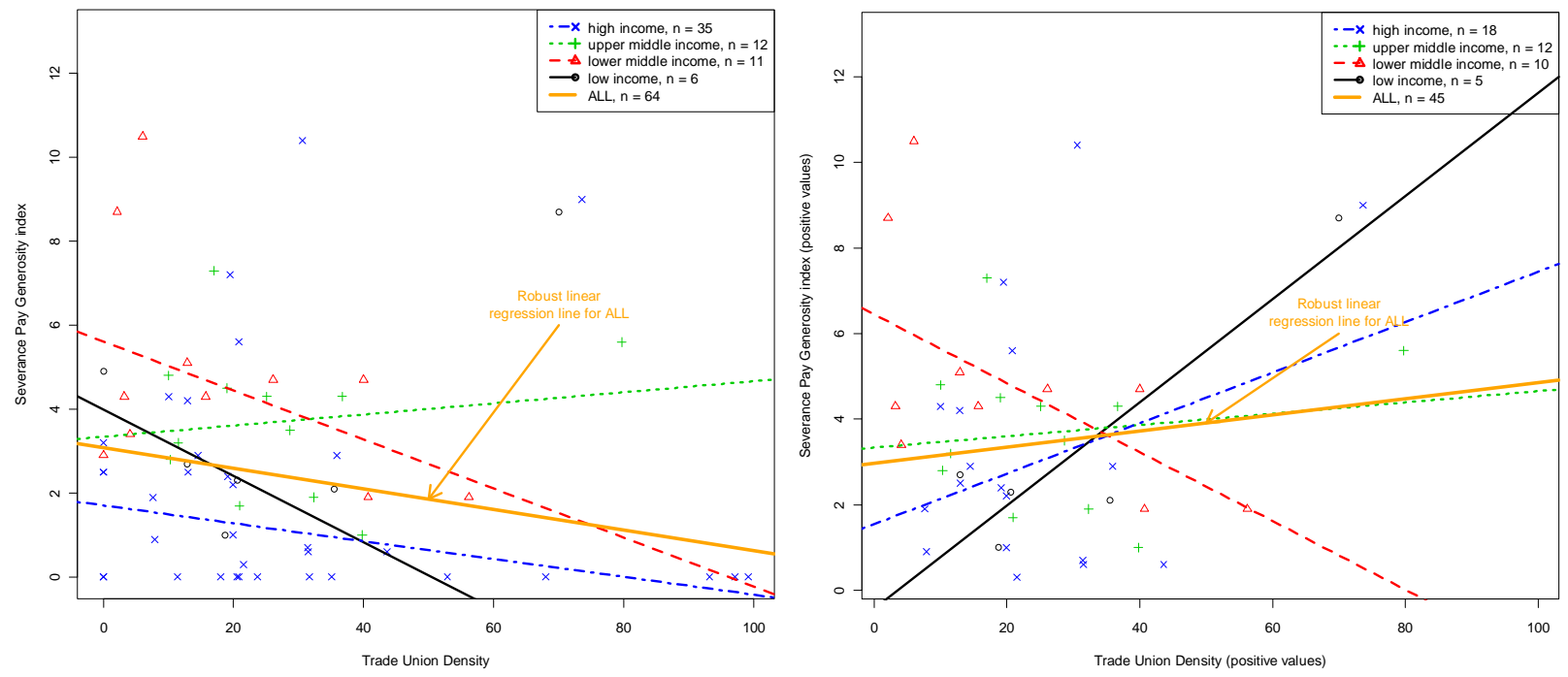

Source: Own computations based on data presented in Annex 2.

We end this subsection by providing multivariate estimates of severance generosity. In the basic model we regress the generosity of severance pay on log of per-capita income, the generosity of unemployment and pension benefits, the notice period and union density.

$\mathrm{G}-\mathrm{SP}=\mathrm{a}+\mathrm{b} \log (\mathrm{pc}-\mathrm{GDP})+\mathrm{c}$ G-UB $+\mathrm{d}$ G-PB + e NP + f UD + u

with

G-SP

Log (pc-GDP)

G-UB

G-PB

NP

UD

$\mathrm{u}$
Generosity Index of Severance Pay (weeks per year of service)

Logarithm of per-capita GDP (2009, in US\$)

Generosity of Unemployment Benefits (replacement rate for av. worker)

Generosity of Pension Benefits (replacement rate for av. worker)

Notice period (in weeks)

Union Density (share of unionized labor in work force)

Residual

In an extended model we introduce additional variables that try to assess if benefit regimes (e.g. unemployment insurance vs. assistance, or PAYG vs. funded pensions), country income groupings, or regions exert significant influence. 
Controlling for different explanatory variables at the same time should enhance confidence in our estimates. However, not all variables are available for all countries which reduces the sample size as we add more variables.

The basic model for all values, across separate and simultaneous estimations suggests the following results (see Table 4.1):

- a consistently negative and significant impact of per-capita GDP on severance pay generosity

- a consistently negative impact of unemployment benefit generosity that is only weakly significant in some models

- a consistently positive and mostly significant impact of pension benefit generosity

- an inconsistent and never significant impact of notice period

- a consistently negative but only sporadically significant impact of union density

Adding further variables to the basic model does not typically change the sign of the coefficients but often renders them insignificant. The explanatory power is often, but not always, taken over by the income grouping as well as the regional dummies (results not shown). The significance is increased once robust estimation is undertaken. Other specifications and estimations (e.g. using a probit approach or polynomial specification of the income term - with and without log) did not lead to improvements in the results. For further details on the estimation, see Annex 3.

Applying the basic model to positive values only reduces the number of observations to 19 and renders all coefficients, except for the per-capita income, insignificant. The change in signs, however, is consistent with the observations in the figures above and a regime change between all generosity and positive generosity values only. For example an increase in union density is consistent with the conjectured increase in generosity of severance pay.

In summing-up this subsection, the following tentative results are suggested. They serve as an amuse-gueule for further and more details investigations and estimations:

- The Figures in Section 3 and Subsection 4.2, and the estimations across all models suggest a strongly negative and significant link between severance pay generosity and per-capita income (or economic wellbeing of a country). A mild inverse U-shaped relation to income has limited statistical support. Furthermore, high income countries have much less tendency to mandate severance pay, instead leaving it to contractual agreements at the sector or firm level.

- The results are broadly consistent with the social benefit view of severance pay and with substitutability with unemployment benefits. But the data suggest a changing function across the income level of countries with stark complementarity for low income countries that is gradually reduced until it turns toward substitutability for high income countries.

- In contrast, the associations with pension benefits do not confirm the social policy function of severance pay. The two benefits seem to be complementary across country income levels, and this relationship is robust and mostly significant. Hence, as in the case studies of Austria, Italy and Korea, the transformed severance pay may serve to complement potentially reduced future pension benefits but such a reduction does not emerge from the cross-country estimations. 
Table 4.1: Drivers of Generosity of Severance Pay: Results for Basic Model

\begin{tabular}{|c|c|c|c|c|c|c|c|c|c|c|}
\hline Model & 1 & 2 & 3 & 4 & 5 & 6 & 7 & 8 & 9 & 10 \\
\hline \multirow{2}{*}{ (Intercept) } & $4.80^{* * *}$ & $4.36^{* *}$ & $2.24^{* * *}$ & $7.71^{* * *}$ & $1.83^{* * *}$ & $8.79 * * *$ & $3.09^{* * *}$ & $5.03^{* * *}$ & $2.43^{* * *}$ & $7.29 * *$ \\
\hline & (0.96) & (1.45) & $(0.25)$ & (1.10) & $(0.47)$ & (1.88) & $(0.42)$ & $(0.95)$ & $(0.34)$ & (2.13) \\
\hline \multirow{2}{*}{$\begin{array}{l}\text { log. GDP per } \\
\text { capita }\end{array}$} & $-0.32 * *$ & -0.28 & & $-0.78 * * *$ & & $-0.65 * *$ & & $-0.31 * *$ & & $-0.59 *$ \\
\hline & $(0.11)$ & $(0.18)$ & & (0.13) & & $(0.20)$ & & (0.10) & & $(0.26)$ \\
\hline \multirow{2}{*}{$\begin{array}{c}\text { Unemp. } \\
\text { Benefit } \\
\text { Generosity }\end{array}$} & & -0.003 & $-0.017 *$ & & & & & & & -0.03 \\
\hline & & $(0.01)$ & $(0.01)$ & & & & & & & $(0.01)$ \\
\hline \multirow{2}{*}{$\begin{array}{c}\text { Pension } \\
\text { Benefit } \\
\text { Generosity }\end{array}$} & & & & $0.03^{* * *}$ & 0.01 & & & & & $0.03^{* * *}$ \\
\hline & & & & $(0.01)$ & $(0.01)$ & & & & & $(0.01)$ \\
\hline \multirow{2}{*}{$\begin{array}{c}\text { Union } \\
\text { Density }\end{array}$} & & & & & & -0.02 & -0.03 & & & $-0.02 *$ \\
\hline & & & & & & $(0.01)$ & $(0.01)$ & & & $(0.01)$ \\
\hline Notice & & & & & & & & -0.05 & -0.05 & 0.10 \\
\hline $\begin{array}{l}\text { Period } \\
\text { (weeks) }\end{array}$ & & & & & & & & $(0.05)$ & $(0.05)$ & $(0.06)$ \\
\hline R-squared & 0.10 & 0.11 & 0.07 & 0.40 & 0.02 & 0.41 & 0.12 & 0.11 & 0.01 & 0.69 \\
\hline $\begin{array}{c}\text { adj. R- } \\
\text { squared }\end{array}$ & 0.09 & 0.09 & 0.06 & 0.38 & 0.01 & 0.39 & 0.11 & 0.10 & 0.01 & 0.64 \\
\hline $\mathbf{N}$ & 175 & 153 & 157 & 80 & 81 & 63 & 64 & 175 & 181 & 39 \\
\hline
\end{tabular}

Source: Authors estimates

Notes: Asterisks $(*, * *, * * *)$ signal significance at 10, 5 and $1 \%$ error interval; values in brackets below the coefficients depict the standard deviation; $\mathrm{N}$ the number of observations.

- There is no consistent and statistically significant link between severance pay generosity and notice period. The bivariate analysis hints at substitutability if zero and positive values are considered and at complementarity for positive values only, although this result may be a spurious.

- The relationship between severance pay generosity and trade union density is mostly negative, with stable and at times significant parameters. Such a result is at odds with a power theory of trade unions and generosity. Again, a bivariate analysis hints at substitutability if zero and positive values are considered and to complementarity for positive values only.

- Last but not least, the use of regional dummies suggests homogeneity within regions and variation between regions, but mainly between OECD and Non-OECD countries. Regional effects of reforms with innovators and followers may have been at work for severance pay programs; there are strong indications for such processes in the area of pensions (see Orenstein, 2003). 


\subsection{Brief Review of the Efficiency Effects of Severance Pay}

Another way to explore the economic rationale of severance pay is by examining the established empirical effects of severance pay by other researchers. If they show that severance pay increases efficiency, that would yield support to the human resource management hypothesis; in the opposite case, the evidence would support the job protection hypothesis. The problem is, however, that very few investigations exist that measure the impact of severance pay on labor market outcome directly and in a convincing manner. Empirical studies are typically of crosscountry type and hence little robust and methodologically reliable. Furthermore, most of the studies focus on broader job protection indicators and measurement and hence a mingling of the effects.

We are not aware of direct empirical evidence on the positive effects of severance pay on firm productivity (based on firm-level data). Nickell and Layard (1999) find a positive effect of employment protection on aggregate growth, but the effect disappears once differences in the level of productivity among countries are controlled for. Moreover, it is not clear which circumstances and interactions may be instrumental for such effects. ${ }^{11}$ Likewise, Koeniger (2005) reports a weak positive relationship between EPL strictness and R\&D intensity in OECD countries.

On the other hand, there is considerable evidence suggesting negative efficiency effects of mandatory severance pay. There are a number of studies which show that strict employment protection including hiring and firing rules as well as severance pay reduces employment. Among the early studies, Lazear (1990) finds that severance pay increases unemployment and reduces both employment and labor force participation (in their "update" of his findings, Addison and Teixeira (2003) confirm the first finding, but cast some doubt on the others). Fallon and Lucas (1991) show that strengthening job security regulations led to a strong decline of employment in India and Zimbabwe.

More recent studies confirming the link between job security and lower employment levels include Haffner et al (2001), for OECD countries, Heckman and Pages (2000), for OECD and Latin American countries, Haltiwanger, Scarpetta and Vodopivec (2003) for OECD and transition countries, Besley and Burgess (2004) and Ahsan and Pages (2009) for India and Saavedra and Torero (2004) for Chile. Heckman and Pages (2000) attribute a reduction in employment of 5 percentage points to job security provisions in Latin America. Montenegro and Pagés (2004) report that job security regulations in Chile reduced employment opportunities of the young and the unskilled while promoting the employment rates of skilled and older workers. OECD (1999) finds insignificant effects on overall employment rates, but points out that negative effects are concentrated among prime age women, the youth, and older workers. To the extent severance pay increases youth unemployment, this has additional negative consequences in terms of the persistence of unemployment and reduced future earnings capacity. Kugler and Pica (2008) and Boeri and Jimeno (2005), on the contrary, ascertain small or no effect of an increase in dismissal cost for Italian firms with fewer than 15 employees on overall employment

\footnotetext{
11 A stream of literature on the effects of worker-management, cooperation, and participatory approaches in management finds mildly positive effects of these features on productivity of firms, but cannot pinpoint the exact ingredients and their interactions which contribute to the success. Tyson and Levine (1990) do single out measures to enhance substantive participation as instrumental for higher productivity - but it is unclear to what extent employment protection boosts such measures.
} 
or employment growth, whereas Schivardi and Torrini (2008) find only modest effects of stricter employment protection on firm growth near the threshold of 15 workers. Studies also show that severance pay contributes to part-time employment and self-employment. Moreover, De Ferranti et al. (2000) report that severance pay systems produce large litigation costs (arising from disputes over the cause of separation) in Latin America.

There is also mounting evidence that employment protection reduces inflows to and outflows from unemployment. By doing so, it contributes to longer unemployment spells (stagnant unemployment pool); flows through employment may not be affected that strongly (for a recent survey, see OECD(1999 and 2004) and for evidence on transition economies, Haltiwanger et al, 2003; see also Botero et al., 2004; Kugler and Saint-Paul, 2004; and Kugler, 1999, 2004). Reduced labor market flows may hinder labor force adjustment and the reallocation of jobs, and may thereby slow down aggregate productivity growth (see Davis and Haltiwanger, 1999, for a survey of the effects of job reallocation on aggregate productivity growth).

Moreover, there is also evidence that job protection reduces productivity and overall growth. The influential OECD (1999) study assessed the extent of job protection against individual dismissal for a regular employee who is given notice on personal ground or due to economic redundancy. The study considers the strictness of employment protection based on three criteria: procedural inconveniences the employer faces when trying to dismiss employees; notice and severance pay provisions; and prevailing standards and penalties for "unfair" dismissals. Based on a synthetic index of these three elements of employment protection components, recent empirical results indicate that higher firing costs adversely affect workers' productivity and economic growth (Scarpetta et al. 2002). Exploiting firm-level micro data Autor et al. (2007) show that the adoption of stricter job security provisions in the United States had a positive effect on capital investment and a negative effect on total factor productivity. Similar findings are provided by Cingano et al. (2010) using Italian data to examine a 1990 reform that raised dismissal costs for Italian firms with fewer than 15 employees only. Micco and Pages (2006) also find some weak evidence of a negative relationship between dismissal costs and labor productivity for 18 OECD and non-OECD countries - albeit due to the presence of Nigeria in the sample. Scarpetta and Tressel (2004) show that strict employment protection has a significant negative impact on productivity, but only in countries with an intermediate degree of centralization/coordination in wage bargaining. OECD (2007) and the revised analysis in Bassanini et al. (2009) based on difference-in-differences approach for 16 OECD countries suggests that mandatory dismissal regulations have a negative impact on productivity growth in industries where dismissal restrictions are more likely to be binding.

There is strong and rising evidence that employment protection legislation and processes have negative effects on worker separation and accession, and therefore on turnover, with consequences for sector composition and economic growth. Among recent studies based on micro data, Autor et al. (2007) show that the adoption of wrongful-discharge protections by state courts in the United States had a negative effect on job flows and firm entry. Similarly, Boeri and Jimeno (2005) and Kugler and Pica (2008) confirm negative effects of an increase in dismissal costs on job turnover in Italian firms. Kugler (1999, 2004) and Kugler et al. (2003) find that reduction in dismissal costs increased accessions as well as separations of workers in Colombia and Spain, respectively. Kahn (2007) reports that EPL reduces the separation rates of those already employed (mostly prime age adults), at the expense of new entrants and the more highly mobile, i.e. young and less skilled. On the contrary, no evidence that dismissal protection 
affected worker flows were found by microeconometric studies for Germany (Bauer et al., 2007), Portugal (Martins, 2009) and Sweden (von Below and Thoursie, 2010). The negative impact of employment protection on turnover was confirmed also by cross-country studies performed on aggregate data (see Gomez-Salvador et al., 2004; Messina and Vallanti, 2007; Boeri and Garibaldi, 2009). To similar conclusions arrive also studies exploiting difference-in-differences approach on OECD countries (see Micco and Pages, 2006; Haltiwanger et al., 2010; Bassanini et al., 2010; Cingano et al., 2010; and OECD, 2010), by which the negative relationship between dismissal costs and job flows is greater in industries with greater propensity to reallocate labor.

The effects of employment protection legislation described above, however, need to be separated from the effects of severance pay, at least for the richer countries where these studies have been mostly performed. In a critical review of the empirical literature Parsons (2011b) comes to the conclusion that "severance pay, unaccompanied by other labor regulations have little impact on workers separation (and accession) or average employment level." Furthermore, he adds that the impact of EPL reforms may depend on the regulatory environment in the economy as a whole, and there may be important interactions between severance pay mandates and collective bargaining rules.

The evidence from the U.S. emphasizes both the role of trade unions in expanding the coverage of severance pay and the use of severance pay as a human resource management tool. In his thorough review of severance pay programs for the period 1930-99, Parsons (2005a,b) reports that severance pay among clerical and sales workers is only modestly less extensive than the coverage of managers and professionals. But he argues that the evolution of formal coverage of blue collar workers is intimately related to the development of the organized labor movement that is, controlling for worker occupation, union status significantly increases the likelihood of severance pay coverage (Parsons 2005a). This means that the prevalence of severance pay for managers and professionals is likely driven also by the efficiency wage considerations. Interestingly, Parsons (2005a,b) also reports that in the U.S., large firms are more likely to have formal severance pay plans than small firms.

The above summary of the findings suggests that economists have indeed shown that employment protection legislation matters for labor market outcomes. Nevertheless severance pay systems alone seemingly have no significant impact, at least in upper middle to high income countries where most of these studies have been undertaken. Yet, it has not yet been investigated to what extent mandated severance pay could become the binding constraint once other employment protection legislation has become less restrictive. For low and lower middle income countries where unemployment benefits are still the exception but severance pay the rule, the impact on labor market outcomes and the effectiveness as unemployment support program still awaits comprehensive investigation and future research. 


\section{Conclusions}

Severance pay programs for formal sector works exist in most countries around the world, often providing the only formal income support to the worker made redundant - yet little is known about the working of these programs, particularly in developing countries. In order to help filling that gap, the present study described the origin of these programs; summarized the salient features of severance pay programs throughout the world; formulated and examined hypotheses about the economic rationale for the existence of these programs; and reviewed recent reforms of these systems.

The study showed that the origin of mandated severance pay can be traced to three main events: the creation of labor codes; the first events of large scale industrial restructuring starting at the end of the $19^{\text {th }}$ century and pressures of the interwar high unemployment episode; and the expansion of the welfare state after WWII. Despite these common origins, the review of existing severance pay programs showed that countries use widely differentiated designs, or at least parameter values.

The inventory of mandated severance pay programs and related social policy and country indicators in 183 countries offers a rich information base to better understand the program and allow for first hypothesis testing. E.g. the data supports the hypothesis of the wide spread nature of severance pay across the world: Of the 183 countries, all except 13 (i.e. 7 percent) provide mandated or quasi-mandated severance pay; the latter are largely concentrated on high income and inexistent in low income countries. While high-income/OECD countries tend to use less generous programs and are less likely to mandate such systems, many low and middle-income countries offer the most generous systems, and rely on compulsion. In most countries, employers account for severance payments as a current operating expense, and few institutional arrangements exist for assuring that firms are able to meet their severance pay obligations to separating workers.

The paper also examined the economic rationale for severance pay and found partial support for all three hypotheses it advanced: that severance pay serves as a social benefit payment, a human resource management tool, and a job protection mechanism.

Evaluations of both income protection and efficiency properties of severance pay programs, usually done for developed countries and mostly as part of a broader assessment of employment protection legislation, are typically fairly negative. The direct estimation of severance pay effects for developed economies, however, indicates few and limited effects once separated from other restrictive employment protection measures. If confirmed by other studies that are able to isolate the pure severance effects on employment outcomes, this may call to think about a better integration of severance pay with other social benefits, in particular of unemployment and retirement, where they exist. If further studies were to show the absence of efficiency effects of mandated compared to voluntary severance pay arrangements as human resource instrument, this may call for rethinking the mandate.

An interesting finding of the paper - which should be considered seriously by policymakers in developing countries - is that severance pay (and job protection in general) of developed countries poses less restrictions on employers as the one of developing and transition countries: it offers less generous payments, it is more simple to administer (and hence it generates less costs), and it is often not mandated but determined by collective bargaining or firm level decisions. This is another indication that in a globalized world, improving labor market outcomes and increasing 
productivity by the creation of a more flexible labor market - among others by liberalizing overly restrictive employment protection legislation - is inescapable.

The absence of unemployment benefits in low and middle countries often leads to high employment protection through mandated severance pay as well as dismissal rules. The challenge will be to move toward less restrictive employment protection legislation while providing effective and incentive oriented income support schemes in a job-enabling environment- i.e. the quest for a low and middle income country' version of "flexicurity". Moving along these lines would suggest to reduce the notional generosity while improving compliance and hence the effective generosity. And low and middle income countries should explore the introduction of Individual Savings Accounts that provide a risk management instrument against a broad range of risks, and the reforms needed to create the enabling environment for such accounts.

Despite recent promising reforms by several countries, finding the best avenues for reforming severance pay remains a task for future research. Critical contributions for such a research are suggested in three areas. First, it would be useful to disentangle better the individual and joint effects of the Employment Protection Legislation (EPL), with severance pay being one of its components. If severance pay programs were to have non-positive effects on labor market outcomes one could think about replacing the mandate by contractual arrangements or by folding them into other social benefits. Second, another fruitful area is investigating the efficiency effects of voluntary severance pay programs for itself and also compared to other and more modern remuneration schemes that attempt to improve and capture knowledge by workers. The result would provide decision information on de-mandating the severance pay. Last but not least, it will be important to explore the liquidity preferences of workers as they seem to explain much of the support for the continuation of existing severance pay programs and the rejection of folding them into unemployment benefit or corporate pension schemes. 


\section{References}

Abraham, Martin and Bernhard Prosch. 2002. "Longterm employment relationships by credible commitments: The Carl Zeiss Foundation”, Rationality and Society, 12(3), 283-306.

Addison, J. and P. Teixeira. 2005. "What Have We Learned About The Employment Effects of Severance Pay? Further Iterations of Lazear et al.”, Empirica, Vol. 32:345-368.

Addison, J. and P. Teixeira (2001). “The Economics of Employment Protection,” IZA Discussion Paper No 381.

Angel-Urdinola Diego F. and Arvo Kuddo. 2010. Key Characteristics of Employment Regulation in the Middle East and North Africa. The World Bank, Social Protection Discussion Papers No. 1006, July.

Acevado, G. and P. Eskenzi. 2003. "The Chilean Unemployment Insurance: A new model of income support available for unemployed workers?,” paper presented at the World Bank/IIASA/Ludwig Boltzmann Institute International Workshop on Severance Pay Reform: Toward Unemployment Savings and Retirement Accounts, Laxenberg/Vienna, November 7-8, 2003

Ahsan, A. and C. Pagés. 2009. "Are All Labor Regulations Equal? Evidence from Indian Manufacturing,” Journal of Comparative Economics, 37(1): 62-75.

Alvarez, F. and M. Veracierto. 2001.. "Severance Payments in an Economy with Frictions", Journal of Monetary Economics 47(4): 477-498.

Asher M., Mukhopadhaya P. 2003. "Severance pay in selected Asian countries: A survey." Prepared for an international workshop on severance pay reform.

Autor, D. H., W. R. Kerr and A. D. Kugler. 2007. "Does Employment Protection Reduce Productivity? Evidence from US States”, The Economic Journal, 117(521): 189-217.

Bernstein, S., E. Fajnzylber and P. Gana. 2011. "The New Chilean Unemployment Insurance System: Combining Individual Accounts and Redistribution in an Emerging Economy”, in Holzmann and Vodopivec, eds, Chapter 9, op, cit.

Bassanini, A., L. Nunziata. and D. Venn. 2009. "Job Protection Legislation and Productivity Growth in OECD Countries”, Economic Policy, 24(04): 349-402.

Bassanini, A., A. Garnero, P. Marianna and S. Martin. 2010. "Institutional Determinants of Worker Flows. A Cross-country/Cross-industry Approach”, OECD Social, Employment and Migration Working Paper, No. 107.

Bauer, T., S. Bender and H. Bonin. 2007. "Dismissal Protection and Worker Flows in Small Establishments”, Economica, 74(296): 804-821.

Basu, K., Horn, H., Shapiro, J., and Roman, L. 2003. International Labor Standards - History, Theory and Policy Options, Blackwell Publishers.

Besley, T. and R. Burgess. 2004. "Can Labor Regulation Hinder Economic Performance? Evidence from India,” Quarterly Journal of Economics, 119(1): 91-134. 
Betcherman, G., A. Luinstra, M. Ogawa. 2001. "Labor Market Regulation: International Experience in Promoting Employment and Social Protection”, The World Bank, Social Protection Discussion Paper No. 0128, November 2001.

Boeri, T. and P. Garibaldi. 2009. “Beyond Eurosclerosis”, Economic Policy, 24(07): 409-461.

Boeri, T. and J. F. Jimeno. 2005. "The Effects of Employment Protection: Learning from Variable Enforcement”, European Economic Review, 49(8): 2057-2077.

Botero, J., S. Djankov, R. La Porta and F. C. Lopez-de-Silanes. 2004. "The Regulation of Labor”, The Quarterly Journal of Economics, 119(4): 1339-1382.

Botero, J., Djankov, S., La Porta, R., Lopez-de-Silanes, F. And Shleifer, A. 2002. The Regulation of Labor, processed.

Calcagno, R, R. Kraeussl, and C. Monticone. 2007. An Analysis of the Effects of the Severance Pay Reform on Credit to Italian SMEs. Center for Research on Pensions and Welfare Policies, WP 59/07.

Cesaratto, S. 2008. The Macroeconomics of the Pension Fund Reforms and the Case of the Severance Pay Reform in Italy. University of Siena - Quaderni del Dipatimento di Economia Politica No. 549, December.

Cesari, R., G. Grande and F. Panetta. 2008. Supplementary Pension Schemes in Italy: Features, Development and Opportunities for Workers. MEFOP. Working Paper No 18.

Cingano, F., M. Leonardi, J. Messina and G. Pica. 2010. “The Effects of Employment Protection Legislation and Financial Market Imperfections on Investment: Evidence from a Firm-Level Panel of EU Countries”, Economic Policy, 25(01): 117-163.

Corsini, L., P. M. Pacini and L. Spataro. 2010. TFR vs Pension Funds : A Model for the Analysis of the Incentives to Adhere to the Second Pillar in Italy. MEFOP. Working Paper No 25.

Davis, S., and J. Haltiwanger. 1999. “Gross Job Flows.” In Ashenfelter and Card (eds.), Handbook of Labor Economics, Amsterdam: North Holland.

De Ferranti, D., G.E. Perry, I. S. Gill, and L. Serven. 2000. Securing Our Future in a Global Economy. World Bank Latin and Caribbean Studies, Washington, D.C.: World Bank.

Fallon, P.R. and R.E.B. Lucas. 1991. "The Impact of Changes in Job Security Regulations in India and Zimbabwe", World Bank Economic Review, 5(1): 395-413.

Ferrer, A. and C. Riddell. 2011. "Unemployment Insurance Savings Accounts in Latin America: Overview and Assessment”, in Holzmann and Vodopivec, eds, Chapter 7, op, cit.

Fugazza. C. and F. Teppa. 2005. An Empirical Assessment of the Italian Severance Pay (TFR). Center for Research on Pensions and Welfare Policies, WP 38/05.

Garibaldi, P. and Pacelli, L. 2003. “Mandatory Severance Payments in Italy: Do they exist?”, paper prepared for the joint World Bank/International Institute for Applied System Analysis/Ludwig Boltzmann Institute for Economic Analysis Workshop on Severance Payments, IIASA/Luxenburg, November 7 and 8, 2003.

Garibaldi, P. and Pacelli, L. 2004. "Firm-Worker Transfers at the End of the Employment Relationship: The Case of Italy.” Working Paper. Collegio Carlo Alberto. 
Gomez-Salvador, R., J. Messina and G. Vallanti. 2004. "Gross Job Flows and Institutions in Europe”, Labour Economics, 11(4): 469-485.

Grund, C. 2003. “Severance Payments for Dismissed Employees in Germany.” Bonn: The Institute for the Study of Labor.

Haffner, R., S. Nickell, G. Nicoletti, S. Scarpetta, and G. Zoega. 2001. "European Integration, Liberalization and Labour Market Performance.” In G. Bertola, T. Boeri and G. Nicoletti, eds., Welfare and Employment in a United Europe, Boston: The MIT Press.

Haltiwanger, J, S. Scarpetta, and M. Vodopivec. 2003. "How Institutions Affect Labor Market Outcomes: Evidence From Transition Countries," paper presented at the WB Economist Forum, April, 71p.

Haltiwanger, J.S. S. Scarpetta, and H. Schweiger. 2008. “Assessing Job Flows Across Countries: The Role of Industry, Firm Size, and Regulations,” NBER Working Paper 13920, April 2008.

Haltiwanger, J., S. Scarpetta and H. Schweiger. 2010. “Cross Country Differences in Job Reallocation: The Role of Industry, Firm Size and Regulations”, EBRD Working Paper, No. 116.

Hawkins, E., 1940. "Dismissal Compensation. Voluntary and Compulsory plans used in the US and abroad.” Princeton University Press.

Hawkins, E.1942. "Dismissal Compensation and the War Economy.” Committee on Social Security of the Social Science Research Council.

Heckman, J. J., and C. Pages. 2000. "The Cost of Job Security Regulation: Evidence from Latin American Labor Markets.” NBER Working Paper No. 7773.

Heckman, J. J., and C. Pages. 2004. “Introduction,” in Heckman and Pagés, eds., Law and Employment: Lessons from Latin America and the Caribbean. Chicago: The University of Chicago, 1-107.

Herz, E., 1954. "Protection of employees on the termination of contracts of employment." International Labour Review Vol 69., No. 4: 295-320.

Hewitt Associaltes LLC. 2002. Hewitt International Report. Available at http://was4.hewitt.com/hewitt/

Hofer, H., U. Schuh and D. Walch. 2011. "Effects of the Austrian Severance Pay Reform”, in Holzmann and Vodopivec, eds, Chapter 5, op, cit

Holzmann, R. 1987. Integration von Abfertigungszielsetzungen in das soziale Sicherungssystem, in: Genser, B. (Hrsg.): Abfertigungen im Spannungsfeld der Wirtschaftspolitik - Eine interdisziplinäre Analyse, Vienna: Manz Verlag.

Holzmann, R. and M. Vodopivec. 2011a, eds. Reforming Severance Pay: An International Perspective. World Bank: Washington, DC., in print.

Holzmann, R. and M. Vodopivec. 2011b. "Severance Pay under Review: Issues, Overview, Policy Conclusions, and Research Agenda”, in Holzmann and Vodopivec, eds., Chapter 1, op. cit.

Iglesias, Augusto, and Robert Palacios. 2001. "Managing Public Pension Reserves: Evidence from the International Experience.” In New Ideas about Old-Age Security, ed. Robert Holzmann and Joseph Stiglitz. Washington, DC: World Bank. 
International Labor Organisation. 2011. NATLEX database. Available at http://natlex.ilo.org/ International Labor Organisation. 2011. Termination of Employment Legislation Digest, http://www.ilo.org/public/english/dialogue/ifpdial/info/termination/

International Monetary Fund. 1998. Venezuela: Recent Economic Developments (1998). IMF Staff Country Report \#98/117. Washington DC: IMF.

International Social Security Association(2003): Social Security Worldwide database. Available at http://www-ssw.issa.int/sswlp2/engl/page1.htm

Jaramillo, M. and J. Saavedra. 2005. "Severance payments in Latin America.” Empirica, Vol. 32:275-307

Kahn, L. M. 2007. "The Impact of Employment Protection Mandates on Demographic Temporary Employment Patterns: International Microeconomic Evidence,” Economic Journal, 117(521): F333-F356.

Kelegama, S. and R. Salih. 1998. "Labor Retrenchment in a Privatization Programme: the Sri Lankan Experience”, Sri Lanka Journal of Social Sciences 21 (1\&2): 1-36.

Koeniger, W. (2005). “Dismissal Costs and Innovation”, Economics Letters, 88(1): 79-85.

Koman, R., Schuh, U. and Weber, A. 2005. "The Austrian Severance Payments Reform: Toward a Funded Pillar". Empirica 32: 255-274. (Revised paper prepared for the joint World Bank/International Institute for Applied System Analysis/Ludwig Boltzmann Institute for Economic Analysis Workshop on Severance Payments, IIASA/Laxenburg, November 7 and 8, 2003).

Kuddo Arvo. 2009. Labor Laws in Eastern European and Central Asian Countries: Minimum Norms and Practices. The World Bank - Social Protection Discussion Papers No. 0920, November.

Kugler A. 2002. "From severance pay to self-insurance: Effects of severance payments savings accounts in Colombia." Center for Economic Policy Research. Available at www.cepr.org

Kugler, A. D. and G. Pica. 2008. "Effects of Employment Protection on Worker and Job Flows: Evidence from the 1990 Italian Reform”, Labour Economics, 15(1): 78-95.

Kugler, A. D. and G. Saint-Paul. 2004. "How Do Firing Costs Affect Worker Flows in a World with Adverse Selection?”, Journal of Labor Economics, 22(3): 553-584.

Kugler, A. D. 1999. "The Impact of Firing Costs on Turnover and Unemployment: Evidence from the Colombian Labor Market Reform”, International Tax and Public Finance Journal, 6(3): 389-410.

Kugler, A. D. 2004. "The Effect of Job Security Regulations on Labor Market Flexibility: Evidence from the Colombian Labor Market Reform”. In J. J. Heckman \& C. Pagés (eds.), Law and Employment: Lessons from Latin America and the Caribbean. Chicago: The University of Chicago Press.

Kugler, A. D., J. F. Jimeno and V. Hernanz. 2003.. "Employment Consequences of Restrictive Permanent Contracts: Evidence from Spanish Labor Market Reforms", CEPR Discussion Papers, No. 3724. 
Lazear, E.P. 1990. “Job Security Provisions and Employment,” Quarterly Journal of Economics 105(3): 699-726.

Lora E., Henao M. 2000. "Colombia: The Evolution and Reform of the Labor market." Washington DC: The Brookings Institution.

MacIsaac D., Rama M. 2001. "Mandatory Severance pay. Its coverage and effects in Peru." Washington DC: The World Bank.

Malo, M. 2000. "A simple model of severance pay determination: the case of individual dismissals in Spain.” Labour - Review of Labour Economics and Industrial Relations. Vol 14. No. 2: 269-290.

Martins, P. 2009. "Dismissals for Cause: The Difference That Just Eight Paragraphs Can Make," Journal of Labor Economics, 27(2): 257-279.

McGill, R. J. Tukey, and A. Wayne A. 1978. "Variations of Box Plots". The American Statistician, 32 (1): 12-16.

Messina, J. and G. Vallanti. 2007. "Job Flow Dynamics and Firing Restrictions: Evidence from Europe,” Economic Journal, 117(521): F279-F301.

Mehmet, O. 1975. "Theoretical aspects of severance pay; a human capital theory approach.” Industrial Relations Centre, Queen's University at Kingston, Canada.

Meyers, Frederic. 1964. Ownership of Jobs - A Comparative Study. Institute of Industrial Relations, University of California.

Micco, A. and C. Pagés. 2006. "The Economic Effects of Employment Protection: Evidence from International Industry-Level Data,” IZA Discussion Paper, No. 2433.

Miron, J., and Weil, D. 1997. "The Genesis and Evolution of Social Security.” NBER working paper No. 5949

Montenegro, C. E. and C. Pagés. 2004. "Who Benefits from Labor Market Regulations? Chile, 1960-1998.” In J. J. Heckman \& C. Pagés (eds.), Law and Employment: Lessons from Latin America and the Caribbean. Chicago: The University of Chicago Press.

Nickell S., and R. Layard. 1999. "Labor Market Institutions and Economic Performance.” In Ashenfelter and Card, eds., Handbook of Labor Economics, Vol.3. North Holland, 1999.

OECD (diverse years): OECD Employment Outlook XXXX. Paris: OECD.

OECD. 1999. Benefit Systems and Work Incentives 1999. Paris: OECD.

OECD. 2004. OECD Employment Outlook 2004. Paris: OECD.

OECD. 2007. OECD Employment Outlook 2007. Paris: OECD.

OECD. 2010. OECD Employment Outlook 2010. Paris: OECD.

OECD (diverse years). Pensions at a Glance. Paris: OECD.

Orenstein, M. 2003. Mapping the Diffusion of Pension Innovations, in R. Holzmann, M. Orenstein and M. Rutkowski. Eds. Pension Reform in Europe: Process and Progress. Directions in Development. Washington, DC: World Bank; pp. 171-193.

World Bank. 2010. Doing Business 2011. Washington, DC: World Bank. 
Palacios R. and M. Pallares-Miralles (2000). “International Patterns of Pension provision.” The World Bank, Social Protection Discussion Paper No. 0009, April 2000.

Parsons, D. 2011a. "Mandated severance pay and firing costs distortions: A critical review of evidence”, in Holzmann and Vodopivec, eds, Chapter 3, op, cit.

Parsons, D. 2011b. “The firing costs implications of alternative severance pay designs”, in Holzmann and Vodopivec, eds., Chapter 4, op, cit.

Parsons, D. 2005. "Benefit Generosity in Voluntary Severance Plans: The U.S. Experience. December 2005. mimeo, George Washington University, Available at SSRN: http://ssrn.com/abstract=877903.

2005a. "The Emergence of Private Job Displacement Insurance in the United States:

Severance Pay Plans 1930-1954” (October 2005). Available at SSRN: http://ssrn.com/abstract $=872331$

2005b. Parsons, Donald O., "Private Job Displacement Insurance in the United States, 1954-1979: Expansion and Innovation” (November 2005). Available at SSRN: http://ssrn.com/abstract $=872334$

2005b. "Private Job Displacement Insurance: Information Asymmetries and Separation Pay Design” (September 2005). Available at SSRN: http://ssrn.com/abstract=878792

Pissarides, C.A. 2001. “Employment Protection”. Labour Economics 8: 131-159.

Rama, M. and R. Artecona. 2002. A database for Labor Market Indicators Across countries. Washington DC: The World Bank.

Ranaraja, S. 2005. “Description and Process Analysis of the TEWA System.” World Bank. Processed.

Reyes, Gonzalo, Jan C van Ours and Milan Vodopivec. 2010. "Incentive Effects of Unemployment Insurance Savings Accounts: Evidence from Chile”, CEPR, Discussion Paper 5971.

Reyes ,G., J. van Ours and M. Vodopivec. 2011. "Incentive Effects of Unemployment Insurance Savings Accounts: Evidence from Chile”, in Holzmann and Vodopivec, eds, Chapter 10, op, cit.

Robalino David A. and Anca Mataoanu. 2005. "Severance Pay in the Middle East and North Africa Region." Working Paper. Middle East and North Africa Region.

Saavedra, J. and M. Torero. 2004. "Labor Market Reforms and Their Impact over Formal Labor Demand and Job Market Turnover: The Case of Peru.” In J. J. Heckman \& C. Pagés (eds.), Law and Employment: Lessons from Latin America and the Caribbean. Chicago: The University of Chicago Press.

Scarpetta, S., P. Hemmings, T. Tressel, T. and J. Woo. 2002. "The Role of Policy and Institutions for Productivity and Firm Dynamics: Evidence from Micro and Industry Data”, OECD Economic Department Working Paper No. 39, Paris (OECD).

Scarpetta, S. and T. Tressel 2004. "Boosting Productivity via Innovation and Adoption of New Technologies: Any Role for Labor Market Institutions?”, The World Bank Policy Research Working Paper Series, No. 3273. 
Schivardi, F. and R. Torrini. 2008. "Identifying the Effects of Firing Restrictions Through SizeContingent Differences in Regulation,” Labour Economics, 15(3): 482-511.

Schwab S. 2003. "Mandated-Severance-Pay Laws in Transition Economies.” Mimeo.

Sulla V., Scarpetta S., Pierre G. 2003. Database for Labor Market Regulations and Institutions across countries, Washington DC: The World Bank.

Towers Perrin. 2003: Towers Perrin reports. Available at http://www.towers.com/towers

Tyson, L. A. and D. I. Levine. 1990. "Participation, Productivity, and the Firm's Environment.” In A.S. Blinder, ed., Paying for Productivity: a Look at the Evidence. Washington, DC: The Brookings Institution.

US Social Security Administration. 2003. "Social Security Programs throughout the World 1999, 2002, 2003.” Available at http://www.ssa.gov/policy/data_sub50.html

Visisombat, K. 1968. "Individual Employment Contracts in the New Labour Codes of FrenchSpeaking Africa”, Employment, International Labour Review, Vol. 98, No. 2, p.121-140.

Vodopivec, M. 2004. "Income Support for the Unemployed: Issues and Options”, The World Bank, Regional and Sectoral Studies..

Vodopivec, M., A. Wörgötter and D. Raju. 2005. "Unemployment Benefit Systems in Central and Eastern Europe: A Review of the 1990s.” Comparative Economic Studies 47(4): 615-651.

Whitehouse, E. 2007. Pension Panorama: Retirement-Income Systems in 53 Countries. Washington, DCL World Bank.

Watson Wyatt Worldwide. 2011. Consulting and Beyond - A Look at Towers Watson Research and Publications. Available at http://www.watsonwyatt.com/

World Bank. 2011. International Patterns of Pension Provisions: A World-wide Overview of Facts and Figures. Social Protection Department, Washington, DC: World Bank, in preparation. Yun, Jungyoll and Jai-Joon Hur J. 2011. "Severance Pay Reform in Korea”, in Holzmann and Vodopivec, eds, Chapter 6, op, cit 


\section{ANNEX 1: Historic Perspectives across Countries and Regions}

For these historic perspectives we combine regional and historical information on severance pay, focusing first on the developments in the United States, UK, and Japan. We then extrapolate some ideas about how severance pay evolved in developing and transition countries, relying on the sparse evidence available on this topic.

\section{Severance Pay History in the United States}

In the US, one of the earliest examples was in 1922 when the Delaware and Hudson Railroad adopted dismissal compensation as part of its benefit program. A large oil company paid dismissal compensation in 1925 when it was implementing a merger. The first big dismissal plan was in the Chicago clothing industry. The Amalgamated Clothing Workers and Hart, Schaffner and Marx had built a comprehensive industrial relations program. About 236 dismissed workers received $\$ 500$ each in 1926. Severance payments ranging from $\$ 150$ - \$500 had been paid on several occasions earlier in the industry. The amounts of compensation were determined more by the financial condition of the firm rather than the needs of the workers due to the prevailing market conditions. The contribution was made by the firm and the remaining workers who temporarily gave up unemployment insurance rights. There were plenty of such incidents in the clothing industry where workers were dismissed due to increased mechanization of the industry. Until 1929, most of the dismissal plans aimed to assist those displaced by mergers, consolidations of offices and plants, or changes in working rules.

Similarly, dismissal plans including severance pay also emerged in several large scale industries such as rubber manufacturing (1929), oil refining (1931 and 1936), banking (1934), public utility(1938), food manufacturing (1938), and auto manufacturing (1940) (Hawkins 1940). In these cases, severance pay plans depended on experience and age of workers, but usually to all employees.

In San Francisco, the building of the Golden Gate and Bay bridges implied displacement of the large workforce employed on ferry boats. A union arbitrator recalled this experience in 1936 (Box 2.3).

The practice of paying compensation to dismissed employees was followed in the US by many

\section{Box A.1 Golden Gate and Bay bridges - Job displacement and Severance Pay}

"Before the bridges, everybody went by ferryboat, and the old railroad commission gave the ferryboat companies a higher return, because they'd be out of business when the bridges opened. But the workers -- what about them? There were about 4,000 of them ...they wanted severance pay, but in 1932 nobody had ever heard of severance pay. The average length of service was 15 years, and we wanted one month's pay for every year of service. To make a long story short, we went to the president of the Southern Pacific railroad, which ran most of the ferries, and told him we wanted severance pay. ... 'Or what?' he said. 'Or we'll go on strike,' I said. Well, there was no way to get across the bay except by ferryboat. So he said, 'I have some figures here for one offer only,' and he turned them over, like cards. He said, 'I'll give you one month's pay for every year of service, and that's it.' Well,.., that was exactly what we were demanding! But we didn't take it right away. We said, 'We'll caucus.' We took it."

Excerpt from interview with Sam Kagel, arbitrator. The San Francisco Chronicle "Ah, the '30s, Full of Struggle And the Joy of Life” Carl Nolte, Sunday, May 2, 1999 
firms even before any unemployment insurance laws were passed. However, legislation on mandatory severance pay was never enacted in the US - not even on the state level - one of the few industrialized countries not to have done so. Instead, it left the issue to the firms and collective agreements to establish and implement. The firms adopted severance payments plans to reward faithful employees, but also as a public relations exercise and to sustain plant morale. Parsons (2005a) noted that during the 1930s, employers adopted different types of advanced notice plans. Flat rate plans largely helped get rid of inefficient labor and served as a mechanism for protection plant morale by quickly dispersing disgruntled workers. Graduated plans seemed to specifically reward workers for their long service to the company. Many companies also had informal or ad hoc plans they applied based on the particular situation of workers. Thus, companies seemed to target different severance plans to different types of workers.

In the 1940s and 50s, severance plans did not expand nearly as much as in the previous decade. Unions became more involved in promoting these plans as part of collective agreements. But severance pay coverage grew much slower than pensions, health or insurance coverage. Severance pay was used when workers were unjustly dismissed, retrenched through consolidation or because of technological change. From the 1970s onward, severance pay coverage decreased. Some industries appeared to drop severance pay plans between 1960s and 1970s. In subsequent decades, severance pay coverage actually decreased despite higher job insecurity. Parsons (2005b) suggests that severance pay was not responsive to demand as its use did not necessarily increase during downturns. In fact, severance pay primarily reflected the employer's desire to limit the morale impact of dismissals.

\section{Severance pay in the United Kingdom}

In the UK during the 1920s, some of the dismissal plans developed as supplements to unemployment insurance. In 1928, Cadbury Brothers Ltd. had to lay off about 500 workers. The chocolate industry had undergone considerable mechanization leading to more efficient processes. The firm in addition to unemployment benefits had a regular plan for dismissal compensation. Special provisions were made for lump sum payments to those moving out of the district, emigrating, or going into business. In England, because of the national insurance law the tendency was toward paying periodic payments of equal sums that did not vary with service or salary of the employee. Trade Unionism was strong in Britain and had secured a number of agreements limiting the employer's absolute right to dismiss.

In subsequent decades, redundancy payments became institutionalized through the Redundancy Payment Act of 1965. This legislation essentially helped the state subsidize industrial restructuring. Redundancy payments were meant to encourage employees to leave employment in declining industries and move to growing sectors. Severance pay also became increasingly useful to address unjust dismissals, which often sparked collective action or strikes. In both UK and New Zealand, severance pay could help decentralize and individualize dismissals, and thereby avoid strikes and better manage labor disputes.

\section{Severance Pay in Japan}

Already before the Japanese "leaving" allowance act was passed in 1936, and before the "fortnight dismissal wage" law of 1926 was enacted, many voluntary schemes of dismissal compensation were adopted by larger enterprises as standard procedure or to meet particular emergencies requiring reductions in work force. Compensation was also paid to those laid off because of sickness, accident or old age, and occasionally to those who quit voluntarily and those 
who are discharged for strike activity. Compensation in the case of non-fault dismissals was more generous which can be attributed to paternalism. The transition of the Japanese feudal economy to an industrial one was so quick that the human feelings of the employer and the sense of justice of the employee heavily influenced dismissal policies.

In June 1935, the Japanese Bureau of Social Affairs conducted a study of all industrial and mining concerns employing 50 or more workers and found that 1,582 firms had written regulations governing leaving allowances. Workers and employers also addressed provisioning for severance pay as early as 1936. In many firms, workers and employers adopted internal regulations for provisioning through contributions by both workers and employers. (Hawkins, 1942) Dismissal plans in Japan were in that period were found to be relatively generous compared to plans in the US.

In summary, developments till WWII suggest that the rising importance of severance payments has been linked many factors. These range from industrial re-structuring, top-ups to flat unemployment benefits and focused originally on a few sectors and white-color workers only. There were also legal arrangements ranging from mandated in labor code or special laws, to general or selective collective bargain arrangements to voluntary schemes.

\section{Historic origins of severance pay in developing and transition countries}

As illustrated in the case of France, the US and UK, the third main element for making severance payments almost ubiquitous in the world is the conscious expansion of social programs after WWII. There was also a distinct trend in the translation or copying of labor market programs from the industrialized North in the de-colonizing South. The development of a "Social Welfare State" in the North led to the gradual expansion of existing programs to ever larger parts of the population, and to the introduction or expansion of related programs, in particular unemployment benefits and old-age pensions. But while severance payments remain typically linked to the labor code and related legislation or collective bargaining arrangements - and hence stem from an employee/employer relationship - the other related social programs are typically established by special social laws and are determined by public action.

In developing countries, the introduction or expansion of severance-type payments has received little attention and only limited references do exist. It has been suggested that the provision of severance pay in a number of developing countries was deemed a somewhat transient legislative measure, the need for which would decline with the development of fuller employment policy and an extensive social security system.

For example, the provision of severance pay was "subject to this obligation coming to an end on the promulgation of legislation concerning social insurance (Costa Rica) or to the replacement of compensation by benefits from a welfare fund (Dominican Republic, Egypt, Lebanon, Syria); see Herz (1954: 319).

In Latin America, the origins and development of severance pay can be assessed by tracing when related legislations were introduced, and how labor movements may have shaped severance pay subsequently. Indeed, legislations on severance pay appeared to concur with the introduction of labor codes in multiple Latin American countries. The first mention of severance pay legislation occurred in Mexico (1917), and later Bolivia (1924 and 1925), Chile (1924), Argentina (1930), Colombia (1934), El Salvador (1935), Peru (1924, 1925, 1930), Venezuela (19360 and Uruguay 
(1944). In most countries, severance pay applied to salaried workers, commercial employees or wage earners.

When considering the rationale for introducing severance pay, Mexico's practice of severance allowances has been interpreted as an "expression of accumulation of property like equity in employment with entitles worker to a form of liquidated damages upon the destruction of his job.” (see Box 2.4).

\section{Box A.2Severance pay in Mexico: Compensation for liquidated damages of job ownership}

Mexico stands out for having early legislation that justified a form of severance pay. As its 1917 Constitution reflects the significant symbolic role of the working class and peasants, specific articles introduced the concept that workers had a right to their jobs. Employers were required to prove that they had just cause for firing a worker. Otherwise, workers were entitled to 3 months wages as indemnity, or could choose reinstatement in their previous job. Should employers refuse reinstatement, then workers received severance pay graduated by years of service in addition to 3 months indemnity pay.

As labor laws evolved to increase protection for workers, employers attempted to limit the class of workers to which these laws applied. Simultaneously, legislation leaned towards reinstatement rather than severance pay in recognition of specific labor market characteristics. Dismissal implied not only a loss of precious seniority, but also starting at the bottom of the job and wage ladder. Severance pay was considered inadequate compensation for such damages. A further rational for reinstatement was the lack of insurance against the risks of job loss. In reality, reinstatement was an unattractive option to workers and employers as both considered their relationship "a broken marriage". Workers feared retribution by their employers, who would make working conditions sufficiently unpleasant so as to induce them to quit. While workers could have accessed a greater settlement by demanding reinstatement, many settled out of court and for less than the statutory severance pay. Union representatives could pressure workers to settle and sanction workers by preventing their further employment in a given industry. Moreover, even when employers had legal justification for large scale dismissal, the burden of proof and onerous legal proceedings made collective bargaining and severance pay the preferred option. Needless to say, severance pay was a luxury afforded only to workers in the formal sector, and the large informal sector had none of such protection.

Based on Meyers (1965): Ownerships of Jobs

In Argentina, the introduction of severance pay followed the consolidation of the early labor movement in 1930 under General Confederation of Labor (CGT). By 1932, CGT had delivered a series of legislative demands on shorter working hours, severance pay, and other welfare measures. These demands would form part of ongoing political debate, and though many would be adopted over the coming years, they lacked enforcement. During the subsequent Peronist era, the creation of labor secretariat helped formalize the relationship between unions and the state and effectively implement such workers benefits and protections.

Several countries also took active measures to ensure funding for severance pay. Chile addressed the funding issue by requiring employers to deposit $8.33 \%$ of each employee's salary (up to 3,500 pesos) with the national savings bank. Employee could collect this amount, plus the interest earned on it, upon termination of employment (Hawkins, 1942). In 1928, Ecuador adopted legislation for provisioning as well though employers were only required to set aside the appropriate salary, not necessarily deposit it in a separate account. 
In many Latin American countries, Herz (1954) noted the strong role of legislation protecting workers and the heavy involvement of courts in dismissal cases (speculating this was the case because of the then weak collective bargaining). For example, in Mexico and Guatemala, employers had to justify dismissals through formal procedures, and employees usually received dismissal compensation unless they were guilty of misconduct. Since then, job protection appears to remain the motivation behind severance pay, or specifically to punish unjust dismissals. Moreover, labor legislations have been layered on top of each other, reflecting the notion that workers have acquired rights and that their benefits should not be curtailed. The historically strong relationship between leftist political parties and unions seems to also explain the promulgation of labor protecting legislation.

In African countries, the introduction of severance pay appears to have been influenced by late colonial relationships. Visisombat (1968) provides interesting reading regarding employment law developments in post-WWII French-speaking Africa. Visisombat reports that prior to 1952 employment law across French overseas territories varied. Employment law in the French overseas territories was standardized with the passing of the 1952 Labor Code for Overseas Territories which brought together "rules scattered through various decrees and orders issued by governors" in Africa. The 1952 Code marked "an important, perhaps even historic, stage in the development of African social legislation" ... "due to the fact that it applied equally to all workers without discrimination on grounds of sex, nationality, legal status or origin and in all African countries for which the Ministry for Overseas France was responsible" ... "but not the North African protectorates (Morocco and Tunisia) or the Algerian departments" (Visisombat, 1968:122). The 1952 Code referred to "separation grants", but only as far as there ["was] provision for them under the contract of employment or collective agreement”. In other words, severance pay was not provided under the 1952 Code on a statutory compulsory basis.

Following independence, a large number of newly independent governments adopted new national labor codes throughout the course of the 1960s. Although country differences have emerged, to a large extent, the 1952 Code has been influential in shaping the development of these new African national codes in the former overseas French territories. Importantly, in the post-colonial era many of the new national labor codes made improvements to better protect the rights of employees threatened with the loss of employment. However, in the immediate postcolonial era, few countries moved toward introducing statutory severance pay. In the late 1960s, the labor codes of Mali, Côte d'Ivoire, and Tunisia were the only examples "giving a legal and compulsory form to this type of grant” [severance pay] (Visisombat, 1968: 138).

One might also note that French severance pay legislation itself evolved only slowly between 1890 and 1950, largely following regional and national plant agreements and bargaining. These laws essentially solidified judge made laws and lower court decisions. Therefore, it may be unlikely that these practices would have been significant in the 1952 code that was transferred to Francophone African countries (as indeed, there was no mention of severance pay therein). It is also worth mentioning that some African countries had severance pay legislation in place before independence. For example, the first mention of severance pay legislation occurred in 1952 in Madagascar. This legislation referred to compensation in case of work stoppages (specifically related to employees in the sugar industry).

In Asia, severance pay dates back to the 1950s in countries such as Sri Lanka and India, while it is more recent in countries such as Thailand and Malaysia. Asher (2003) notes that particularly in India, each amendment to labor legislation has provided greater protection to the worker. Some 
of the practice of severance pay appeared related to retrenchment occurring during the energy crisis $(1973,1979)$ but also reflected that a shortage of raw materials could stop work and lead to retrenchment. In Sri Lanka and India, severance pay would appear to have been a useful measure during economic restructuring. However, the more expensive Voluntary Retirement Schemes were far more common for curtailing the workforce during restructuring. Perhaps the benefits paid under severance pay were insufficient to cut back enough labor.

Particularly in Sri Lanka, the use of voluntary retirement schemes also reflected the highly politicized nature of labor movements. From its inception in the 1930s, the trade union movement was aligned along political parties, rather than occupational categories. From a historical perspective, workers were perceived as the victims of exploitation and needed State support. Moreover, employment security was still considered as an instrument for guaranteeing income security. Thus, job protection (often tied to political patronage) looms large in Sri Lankan labor movements. Altogether, these factors help explain why workers supported trade union representatives during the economic restructuring of the early 1990s. Their representatives could always bargain them a better deal, leading to increasingly larger redundancy compensation packages (Kelegama and Salih, 1998).

There is little information about the origins of severance pay legislations in the Middle East. Herz (1954) documented early legislation that determined advanced notice period. As noted earlier, in Lebanon severance pay was meant to be temporary legislation to be replaced by a welfare fund. However, severance pay is still prevalent in Lebanon today. Severance pay appeared to evolve as part of large social protection systems in this region, reflecting the state's roles both in regulating the labor market and as an employer. Stronger union activity in the early 1990s is also appeared to strengthen severance pay (Robalino and Mataoanu, 2005). While nowadays essential all countries in the Middle East and Northern Africa have severance pay and pension provisions for their formal labor force, very few have to day unemployment benefits (Angel-Urdinola and Kuddo, 2010). A special feature of severance pay concerns the many migrants to the 7 countries of the Gulf Cooperation Council (GCC). For them, severance pay is (besides basic health care) the only social protection benefit and is legislated by the labor code (see Holzmann and Pouget, 2010).

Among former Soviet countries, only Estonia has evidence of early severance pay legislation (1934 and 1936). Severance pay, or any dismissals for that matter, were essentially meaningless during the Soviet times and did not exist. Employees could only be dismissed for extremely limited reasons, each of which required different and complex dismissal procedures. With the transition to the market system, all countries adopted new severance pay legislations and unemployment benefits. While the latter continue covering often very few unemployed workers, severance pay is much more comprehensive and at times notionally generous but also innovative. In a number of countries (including the Czech Republic, Hungary, Poland, and Slovakia), severance pay is not paid in case the worker continues with a new employer ( Kuddo, 2009). 
ANNEX 2: Inventory of Severance Pay across the World 


\begin{tabular}{|c|c|c|c|c|c|c|c|c|c|c|c|c|c|c|c|c|}
\hline & \multicolumn{2}{|c|}{ Legal Base } & \multicolumn{2}{|r|}{ Coverage } & \multirow{2}{*}{\begin{tabular}{|c|} 
Eligible Contingencies \\
$\begin{array}{c}\text { Dismissal/Redundancy } \\
\text { /Bankruptcy/lncapacity } \\
\text { IOld-Age/End-of- } \\
\text { service }\end{array}$
\end{tabular}} & \multicolumn{7}{|c|}{ Defined Benefits for Redundancy } & \multicolumn{2}{|c|}{ End-of-Service Pay } & \multicolumn{2}{|c|}{ Defined Contribution } \\
\hline Country & Mandatory & $\begin{array}{l}\text { Collective } \\
\text { agree- } \\
\text { ments }\end{array}$ & Sectors & Excluded categories & & $\begin{array}{c}\text { Minimum } \\
\text { tenure } \\
\text { required } \\
\text { (months) }\end{array}$ & $\begin{array}{l}\text { Benefits } \\
\text { at } 9 \\
\text { months }\end{array}$ & $\begin{array}{l}\text { Benefits } \\
\text { at } 1 \text { year }\end{array}$ & $\begin{array}{l}\text { Benefits } \\
\text { at } 5 \text { yrs }\end{array}$ & $\begin{array}{l}\text { Benefit } \\
\text { at } 10 \mathrm{yrs}\end{array}$ & $\begin{array}{l}\text { Benefits } \\
\text { at } 20 \text { yrs }\end{array}$ & $\begin{array}{l}\text { Generosity } \\
\text { index }\end{array}$ & $\begin{array}{l}\text { Minimum } \\
\text { tenure } \\
\text { required } \\
\text { (months) }\end{array}$ & $\begin{array}{c}\text { Generosity } \\
\text { index }\end{array}$ & $\begin{array}{l}\text { Minimum } \\
\text { tenure } \\
\text { required } \\
\text { (months) }\end{array}$ & $\begin{array}{c}\text { Contributio } \\
n \text { Rate } \\
\text { (\% of salary) }\end{array}$ \\
\hline Afghanistan & 1 & 0 & .. & .. & $\mathrm{R}, .$. & & 0.0 & 8.7 & 17.3 & 26.0 & 26.0 & 4.9 & & & & \\
\hline Albania & 1 & .. & .. & .. & $\mathrm{D}, \mathrm{R}$ & 36 & 0.0 & 0.0 & 10.7 & 21.4 & 42.9 & 1.4 & & & & \\
\hline Algeria & 0 & 1 & a & .. & $D, R$ & 36 & 13.0 & 13.0 & 13.0 & 13.0 & 13.0 & 5.6 & & & & \\
\hline Angola & 1 & .. & .. & .. & $\mathrm{R}, .$. & .. & 0.0 & 2.2 & 10.8 & 21.7 & 54.2 & 2.2 & & & & \\
\hline Antigua and Barbuda & 1 & .. & .. & .. & $\mathrm{R}, .$. & .. & 0.0 & 2.4 & 12.0 & 24.0 & 48.0 & 2.4 & & & & \\
\hline Argentina & 1 & 1 & $\mathrm{p}$ & $\begin{array}{l}\text { Agricultural workers } \\
\text { and domestic workers }\end{array}$ & $\mathrm{R}$ & .. & 4.3 & 4.3 & 21.7 & 43.3 & 86.7 & 4.3 & & & & \\
\hline Armenia & 1 & 0 & $\mathrm{a}$ & None & $\mathrm{D}, \mathrm{I}$ & . & 4.3 & 4.3 & 4.3 & 4.3 & 4.3 & 1.9 & & & & \\
\hline Australia & 1 & 1 & $p$ & Firm size less 15 & $\mathrm{R}$ & 12 & 0.0 & 4.0 & 10.0 & 12.0 & 0.0 & 2.4 & & & & \\
\hline Austria & 1 & 1 & $\mathrm{p}$ & $\begin{array}{l}\text { Agricultural workers } \\
\text { and domestic workers }\end{array}$ & E & .. & n.a. & n.a. & n.a. & n.a. & n.a. & n.a. & & & 0 & 1.54 \\
\hline Azerbaijan & 1 & .. & $\mathrm{a}$ & Army, Judiciary & $\mathrm{D}, \mathrm{R}$ & .. & 13.0 & 13.0 & 13.0 & 13.0 & 13.0 & 5.6 & & & & \\
\hline Bahamas & 1 &.. &.. & ... & $\mathrm{R}, \ldots$ & .. & 1.5 & 2.0 & 10.0 & 20.0 & 24.0 & 2.0 & & & & \\
\hline Bahrain & 1 & 0 & $\mathrm{p}$ & expats (own system) & $E$ & 12 & n.a. & n.a. & n.a. & n.a. & n.a. & 0.0 & 12 & 1.0 & & \\
\hline Bangladesh & 1 &.. & $\mathrm{p}$ & $\begin{array}{c}\text { Firms size less } 5 \text {, } \\
\text { managerial positions }\end{array}$ & $\mathrm{R}, \mathrm{I}$ & 12 & 0.0 & 5.0 & 25.0 & 50.0 & 100.0 & 5.0 & & & & \\
\hline Belarus & 1 & 1 & $a$ & None & $\mathrm{D}, \mathrm{R}, \mathrm{B}$ & .. & 13.0 & 13.0 & 13.0 & 13.0 & 13.0 & 5.6 & & & & \\
\hline Belgium & 0 & 1 & n.a. & n.a. & n.a. & n.a. & n.a. & n.a. & n.a. & n.a. & n.a. & 0 & & & & \\
\hline Belize & 1 & 0 & .. & .. & $\mathrm{R}, \ldots$ & ... & 0.0 & 0.0 & 5.0 & 10.0 & 20.0 & 0.7 & & & & \\
\hline Benin & 1 & 0 & ... & .. & $\mathrm{D}, \mathrm{R}$ & .. & 0.0 & 1.3 & 6.5 & 14.1 & 31.4 & 1.3 & & & & \\
\hline Bhutan & 0 & 0 & n.a. & n.a. & n.a. & n.a. & n.a. & n.a. & n.a. & n.a. & n.a. & 0 & & & & \\
\hline Bolivia & 1 &.. & $p$ & Agricultural workers & $D, R$ & 3 & $\ldots$ & $\ldots$ & & & ... & ... & & & & \\
\hline Bosnia and Herzegovina & 1 & .. & .. & ... & $D, R$ & 24 & 0.0 & 0.0 & 7.2 & 14.4 & 28.9 & 1.0 & & & & \\
\hline \begin{tabular}{|l|} 
Botswana \\
\end{tabular} & 1 & .. & .. & .. & $D, R$ & 60 & 1.8 & 2.4 & 12.0 & 36.0 & 84.0 & 2.8 & & & & \\
\hline Brazil & 1 & 0 & $\mathrm{p}$ & $\begin{array}{l}\text { Agricultural and } \\
\text { domestic workers }\end{array}$ & $\mathrm{D}, \mathrm{R}, \mathrm{B}, \mathrm{I}, \mathrm{O}-\mathrm{E}$ & & 1.2 & 1.7 & 8.3 & 16.6 & 33.3 & 1.7 & & & .. & 8.00 \\
\hline Brunei Darussalam & 0 & 0 & n.a. & n.a. & n.a. & n.a. & n.a. & n.a. & n.a. & n.a. & n.a. & n.a. & & & & \\
\hline Bulgaria & 1 & 1 & $\mathrm{p}$ & Firm size less 20 & $\mathrm{R}, \mathrm{O}, \mathrm{I}$ & .. & 4.3 & 4.3 & 4.3 & 4.3 & 4.3 & 1.9 & & & & \\
\hline Burkina Faso & 1 & 0 & $\mathrm{p}$ & none & $\mathrm{D}, \mathrm{R}$ & 12 & 0.0 & 1.1 & 5.4 & 11.9 & 29.3 & 1.1 & & & & \\
\hline Burundi & 1 & 0 & .. & .. & $\mathrm{R}, .$. & .. & 0.0 & 0.0 & 8.7 & 13.0 & 13.0 & 1.0 & & & & \\
\hline Cambodia & 1 & 0 & .. & .. & $\mathrm{R}, .$. & .. & 1.0 & 2.1 & 10.7 & 21.4 & 26.0 & 2.1 & & & & \\
\hline Cameroon & 1 & .. & $\mathrm{p}$ & none & $\mathrm{D}, \mathrm{R}$ & 24 & 0.0 & 1.5 & 7.6 & 15.2 & 30.3 & 1.5 & & & & \\
\hline Canada & 1 & .. & a & $\begin{array}{l}\text { Managerial positions } \\
\text { and non-federeally } \\
\text { regulated workers }\end{array}$ & $\mathrm{R}$ & 12 & 0.0 & 0.0 & 5.0 & 10.0 & 20.0 & 0.7 & & & & \\
\hline Cape Verde & 1 & ... & .. & 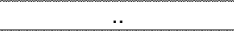 & $R_{, \ldots}$ & $\therefore$ & 3.3 & 4.3 & 21.7 & 43.3 & 86.7 & 4.3 & & & & \\
\hline Central African Republic & 1 & 0 & .. &.. & $\mathrm{R}, .$. &.. & 17.3 & 17.3 & 17.3 & 17.3 & 17.3 & 7.5 & & & & \\
\hline \begin{tabular}{|c|} 
Chad \\
\end{tabular} & 1 & 0 &.. &.. & $\mathrm{R}, .$. &.. & 0.0 & 0.0 & 5.4 & 11.9 & 27.1 & 0.8 & & & & \\
\hline
\end{tabular}




\begin{tabular}{|c|c|c|c|c|c|c|c|c|c|c|c|c|c|c|c|c|}
\hline & \multicolumn{2}{|c|}{ Legal Base } & \multicolumn{2}{|r|}{ Coverage } & \multirow{2}{*}{\begin{tabular}{|c|} 
Eligible Contingencies \\
Dismissal/Redundancy \\
/Bankruptcy/Incapacity \\
/Old-Age/End-of- \\
service
\end{tabular}} & \multicolumn{7}{|c|}{ Defined Benefits for Redundancy } & \multicolumn{2}{|c|}{ End-of-Service Pay } & \multicolumn{2}{|c|}{ Defined Contribution } \\
\hline Country & Mandatory & $\begin{array}{l}\text { Collective } \\
\text { agree- } \\
\text { ments }\end{array}$ & Sectors & Excluded categories & & $\begin{array}{l}\text { Minimum } \\
\text { tenure } \\
\text { required } \\
\text { (months) }\end{array}$ & $\begin{array}{l}\text { Benefits } \\
\text { at } 9 \\
\text { months }\end{array}$ & $\begin{array}{l}\text { Benefits } \\
\text { at } 1 \text { year }\end{array}$ & $\begin{array}{l}\text { Benefits } \\
\text { at } 5 \text { yrs }\end{array}$ & $\begin{array}{l}\text { Benefit } \\
\text { at } 10 \mathrm{yrs}\end{array}$ & $\begin{array}{l}\text { Benefits } \\
\text { at } 20 \text { yrs }\end{array}$ & $\begin{array}{l}\text { Generosity } \\
\text { index }\end{array}$ & $\begin{array}{l}\text { Minimum } \\
\text { tenure } \\
\text { required } \\
\text { (months) }\end{array}$ & $\underset{\substack{\text { Generosity } \\
\text { index }}}{ }$ & $\begin{array}{l}\text { Minimum } \\
\text { tenure } \\
\text { required } \\
\text { (months) }\end{array}$ & $\begin{array}{c}\text { Contributio } \\
n \text { Rate } \\
\text { (\% of salary) }\end{array}$ \\
\hline Chile & 1 & 1 & $\mathrm{p}$ & $\begin{array}{c}\text { Domestic workers and } \\
\text { managerial positions }\end{array}$ & $\mathrm{D}, \mathrm{R}$ & 12 & 0.0 & 4.3 & 21.7 & 10.0 & 47.7 & 3.2 & & & & \\
\hline China & 1 & .. & $\mathrm{p}$ & none & $\mathrm{D}, \mathrm{R}$ &.. & 4.3 & 4.3 & 21.7 & 43.3 & 86.7 & 4.3 & & & & \\
\hline Colombia & 1 & 0 & $\mathrm{p}$ & none & $D, R$ & .. & 4.3 & 4.3 & 15.7 & 30.0 & 58.6 & 3.5 & & & & \\
\hline Comoros & 1 & 0 & ... & ... & $\mathrm{R}, .$. & .. & 4.3 & 4.3 & 21.7 & 43.3 & 86.7 & 4.3 & & & & \\
\hline Congo, Dem. Rep. & 0 & 0 & n.a. & n.a. & n.a. & n.a. & n.a. & n.a. & n.a. & n.a. & n.a. & n.a. & & & & \\
\hline Congo, Rep. & 1 & 0 & .. & .. & $\mathrm{R}, .$. & .. & 0.0 & 0.0 & 6.1 & 13.4 & 29.9 & 0.9 & & & & \\
\hline Costa Rica & 1 &.. & $\mathrm{p}$ & none & $\mathrm{D}, \mathrm{R}$ & .. & 2.0 & 2.8 & 15.2 & 25.1 & 25.1 & 2.8 & & & & \\
\hline Cote d'Ivoire & 1 & 1 & $\mathrm{p}$ & none & $\mathrm{D}, \mathrm{R}$ & 12 & 0.0 & 1.3 & 6.5 & 14.1 & 31.4 & 1.3 & & & & \\
\hline Croatia & 1 &.. & $\mathrm{p}$ & none & $\mathrm{D}, \mathrm{R}$ & 24 & 0.0 & 0.0 & 7.2 & 14.4 & 26.0 & 1.0 & & & & \\
\hline Cyprus & 0 & 1 & n.a. & n.a. & n.a. & n.a. & n.a. & n.a. & n.a. & n.a. & n.a. & n.a. & & & & \\
\hline Czech Republic & 1 & 1 & $\mathrm{p}$ & Firm size less 20 & $\mathrm{R}, \mathrm{I}$ & .. & 13.0 & 13.0 & 13.0 & 13.0 & 13.0 & 5.6 & & & & \\
\hline Denmark & 1 & 1 & $\mathrm{p}$ & $\begin{array}{c}\text { Firm size less 20, } \\
\text { domestic workers, } \\
\text { seafarers, blue collar } \\
\text { workers }\end{array}$ & $\mathrm{D}, \mathrm{R}, \mathrm{E}$ & 144 & 0.0 & 0.0 & 0.0 & 0.0 & 0.0 & 0.0 & & & & \\
\hline Djibouti & 0 & 0 & n.a. & n.a. & n.a. & n.a. & n.a. & n.a. & n.a. & n.a. & n.a. & n.a. & & & & \\
\hline Dominica & 1 & .. & .. & .. & $\mathrm{R}, .$. & ... & 0.0 & 0.0 & 9.0 & 19.0 & 49.0 & 1.2 & & & & \\
\hline Dominican Rep. & 1 & 1 & a & $\begin{array}{l}\text { Freelance, tenants } \\
\text { and sharecroppers, } \\
\text { etc }\end{array}$ & $\mathrm{D}, \mathrm{R}, \mathrm{O}$ & 3 & 2.4 & 3.8 & 20.9 & 41.8 & 83.6 & 4.1 & & & & \\
\hline Ecuador & 1 & .. & $\mathrm{a}$ & none & $\mathrm{D}, \mathrm{R}$ & .. & 13.0 & 14.1 & 27.1 & 54.2 & 108.3 & 8.3 & & & & \\
\hline Egypt, Arab Rep. & 1 & .. & $\mathrm{p}$ & Domestic wokers & $\mathrm{R}$ & .. & 4.3 & 4.3 & 21.7 & 54.2 & 119.2 & 4.7 & & & & \\
\hline El Salvador & 1 &.. & .. & ... & $\mathrm{R}, \ldots$ & ... & 3.2 & 4.3 & 21.4 & 42.9 & 85.7 & 4.3 & & & & \\
\hline Equatorial Guinea & 1 &.. & ... & .. & $\mathrm{R}, .$. & .. & 4.8 & 6.4 & 32.1 & 64.3 & 128.6 & 6.4 & & & & \\
\hline Eritrea & 1 &.. & & & $\mathrm{R}, .$. &.. & 1.5 & 2.0 & 10.0 & 25.0 & 65.0 & 2.2 & & & & \\
\hline Estonia & 1 & .. & ... & ... & $D, R, B$ & ... & 8.7 & 4.3 & 4.3 & 4.3 & 17.3 & 1.9 & & & & \\
\hline Ethiopia & 1 & .. & $\mathrm{p}$ & Managerial positions & $\mathrm{D}, \mathrm{R}, \mathrm{B}$ & .. & 3.2 & 4.3 & 10.0 & 17.1 & 31.4 & 2.7 & & & & \\
\hline Fiji & 1 &.. & .. & .. & $\mathrm{R}, .$. & 12 & 0.0 & 1.0 & 5.0 & 10.0 & 20.0 & 1.0 & & & & \\
\hline Finland & 0 & 1 & n.a. & n.a. & n.a. & n.a. & n.a. & n.a. & n.a. & n.a. & n.a. & 0.0 & & & & \\
\hline France & 1 & 1 & $\mathrm{p}$ & none & $D, R, E$ & 12 & 0.0 & 0.9 & 4.3 & 8.7 & 23.1 & 0.9 & & & & \\
\hline Gabon & 1 & 0 & .. & ... & $\mathrm{R}, .$. & ... & 0.0 & 0.0 & 4.3 & 8.7 & 17.3 & 0.6 & & & & \\
\hline Gambia & 0 & 0 & n.a. & n.a. & n.a. & n.a. & n.a. & n.a. & n.a. & n.a. & n.a. & n.a. & & & & \\
\hline
\end{tabular}




\begin{tabular}{|c|c|c|c|c|c|c|c|c|c|c|c|c|c|c|c|c|}
\hline \multirow[b]{2}{*}{ Country } & \multicolumn{2}{|c|}{ Legal Base } & \multicolumn{2}{|r|}{ Coverage } & \multirow{2}{*}{\begin{tabular}{|c|} 
Eligible Contingencies \\
Dismissal/Redundancy \\
/Bankruptcy/Incapacity \\
IOld-Age/End-of- \\
service
\end{tabular}} & \multicolumn{7}{|c|}{ Defined Benefits for Redundancy } & \multicolumn{2}{|c|}{ End-of-Service Pay } & \multicolumn{2}{|c|}{ Defined Contribution } \\
\hline & Mandatory & $\begin{array}{c}\text { Collective } \\
\text { agree- } \\
\text { ments }\end{array}$ & Sectors & Excluded categories & & $\begin{array}{l}\text { Minimum } \\
\text { tenure } \\
\text { required } \\
\text { (months) }\end{array}$ & $\begin{array}{l}\text { Benefits } \\
\text { at } 9 \\
\text { months }\end{array}$ & $\begin{array}{l}\text { Benefits } \\
\text { at } 1 \text { year }\end{array}$ & $\begin{array}{l}\text { Benefits } \\
\text { at } 5 \mathrm{yrs}\end{array}$ & $\begin{array}{l}\text { Benefit } \\
\text { at } 10 \mathrm{yrs}\end{array}$ & $\begin{array}{l}\text { Benefits } \\
\text { at } 20 \mathrm{yrs}\end{array}$ & $\begin{array}{l}\text { Generosity } \\
\text { index }\end{array}$ & $\begin{array}{c}\text { Minimum } \\
\text { tenure } \\
\text { required } \\
\text { (months) }\end{array}$ & $\underset{\text { index }}{\text { Generosity }}$ & $\begin{array}{l}\text { Minimum } \\
\text { tenure } \\
\text { required } \\
\text { (months) }\end{array}$ & $\begin{array}{c}\text { Contributio } \\
n \text { Rate } \\
\text { (\% of salary) }\end{array}$ \\
\hline Georgia & 1 & .. & $\mathrm{a}$ & none & $\mathrm{D}, \mathrm{R}$ & .. & 4.3 & 4.3 & 4.3 & 4.3 & 4.3 & 1.9 & & & & \\
\hline Germany & 1 & 1 & $\mathrm{p}$ & $\begin{array}{l}\text { Firm size less } 10 \text {, } \\
\text { managerial positions }\end{array}$ & $\mathrm{R}, \mathrm{E}$ & 6 & 0.0 & 2.2 & 10.8 & 21.7 & 43.3 & 2.2 & & & & \\
\hline Ghana & 1 & 1 & $\mathrm{a}$ & Army, state security & $\mathrm{R}$ & .. & 6.5 & 8.7 & 43.3 & 86.7 & 173.3 & 8.7 & & & & \\
\hline Greece & 1 & .. & $\mathrm{a}$ & none & $\mathrm{D}, \mathrm{R}, \mathrm{I}$ & 2 & 24.0 & 24.0 & 24.0 & 24.0 & 24.0 & 10.4 & & & & \\
\hline Grenada & 1 & .. & ... & .. & $\mathrm{D}, \mathrm{R}$ & .. & 0.0 & 1.0 & 5.0 & 10.0 & 20.0 & 1.0 & & & & \\
\hline Guatemala & 1 & .. & .. & .. & $\mathrm{D}, \mathrm{R}$ & .. & 3.8 & 5.1 & 25.3 & 50.6 & 101.1 & 5.1 & & & & \\
\hline Guinea & 1 & .. & ... & ... & $\mathrm{R}, .$. & 12 & 0.0 & 1.1 & 5.4 & 10.8 & 21.7 & 1.1 & & & & \\
\hline Guinea-Bissau & 1 &.. & .. & .. & $\mathrm{R}, .$. & .. & 13.0 & 13.0 & 21.7 & 43.3 & 86.7 & 7.2 & & & & \\
\hline Guyana & 1 & .. & ... & ... & $\mathrm{R}, .$. & 12 & 0.0 & 2.0 & 10.0 & 25.0 & 52.0 & 2.2 & & & & \\
\hline Haiti & 0 & 0 & n.a. & n.a. & n.a. & n.a. & n.a. & n.a. & n.a. & n.a. & n.a. & n.a. & & & & \\
\hline Honduras & 1 & .. & .. &.. & $\mathrm{D}, \mathrm{R}$ & & 3.3 & 4.3 & 21.7 & 43.3 & 86.7 & 4.3 & & & & \\
\hline Hong Kong & 1 & .. & .. & ... & $\mathrm{D}, \mathrm{R}$ & 24 & 0.0 & 0.3 & 1.4 & 2.9 & 5.8 & 0.3 & & & & \\
\hline Hungary & 1 &.. & $\mathrm{p}$ & Firm size less 20 & $\mathrm{D}, \mathrm{R}, \mathrm{B}, \mathrm{E}$ & 36 & 0.0 & 0.0 & 8.7 & 13.0 & 21.7 & 1.0 & & & & \\
\hline Iceland & 0 & 1 & n.a. & n.a. & n.a. & n.a. & n.a. & n.a. & n.a. & n.a. & n.a. & n.a. & & & & .. \\
\hline India & 1 &.. & $a$ & Firm size less 50 & $\mathrm{R}, \mathrm{I}$ & 12 & 2.1 & 2.1 & 10.7 & 21.4 & 42.9 & 2.1 & & & & 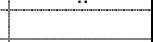 \\
\hline Indonesia & 1 & 1 & $\mathrm{p}$ & Domestic workers & $D, R, B, I, E$ & .. & 4.3 & 13.0 & 34.7 & 56.3 & 108.3 & 8.5 & & & & \\
\hline Iran & 1 & .. & $\mathrm{a}$ & none & $\mathrm{D}, \mathrm{R}, \mathrm{E}, \mathrm{O}, \mathrm{I}$ & .. & 0.0 & 4.3 & 21.7 & 43.3 & 86.7 & 4.3 & & & & \\
\hline Iraq & 0 & .. & n.a. & n.a. & n.a. & n.a. & n.a. & n.a. & n.a. & n.a. & n.a. & n.a. & & & & \\
\hline Ireland & 1 & 1 & .. & none & $\mathrm{R}$ & 24 & 0.2 & 0.7 & 2.6 & 5.0 & 9.8 & 0.6 & & & & \\
\hline Israel & 1 & 1 & .. & $\begin{array}{l}\text { Workers excluded If } \\
\text { employer contirbutes } \\
\text { to pension plan }\end{array}$ & $\mathrm{D}, \mathrm{I}, \mathrm{E}$ & 12 & 0.0 & 4.3 & 21.7 & 43.3 & 86.7 & 4.3 & & & & \\
\hline Italy & 1 & 1 & $\mathrm{p}$ & none & E & & n.a. & n.a. & n.a. & n.a. & n.a. & 0.0 & & & .. & 7.00 \\
\hline Jamaica & 1 & 0 & $\mathrm{p}$ & none & $\mathrm{D}, \mathrm{R}$ & 24 & 0.0 & 0.0 & 10.0 & 20.0 & 50.0 & 1.3 & & & & \\
\hline Japan & 0 & 1 & n.a. & n.a. & n.a. & n.a. & n.a. & n.a. & n.a. & n.a. & n.a. & 0.0 & & & & \\
\hline Jordan & 1 &.. & $\mathrm{p}$ & $\begin{array}{l}\text { Agricultural workers } \\
\text { and domestic workers }\end{array}$ & $\mathrm{D}, \mathrm{R}, \mathrm{E}$ & .. & 0.0 & 0.0 & 0.0 & 0.0 & 0.0 & 0.0 & & & & \\
\hline Kazakhstan & 1 &.. & .. & none & $\mathrm{D}, \mathrm{R}, \mathrm{B}, \mathrm{E}$ & .. & 4.3 & 4.3 & 4.3 & 4.3 & 4.3 & 1.9 & & & & \\
\hline Kenya & 1 &.. & a & Army, police & $\mathrm{R}$ & .. & 1.6 & 2.1 & 10.7 & 21.4 & 42.9 & 2.1 & & & & \\
\hline Kiribati & 0 & 0 & n.a. & n.a. & n.a. & n.a. & n.a. & n.a. & n.a. & n.a. & n.a. & n.a. & & & & \\
\hline Korea & 1 & 0 & $\mathrm{p}$ & None & $D, R, E$ & 12 & 0.0 & 4.3 & 21.7 & 43.3 & 86.7 & 4.3 & & & & \\
\hline Kosovo & 1 &.. & .. & .. & $\mathrm{R}, .$. & .. & 0.0 & 0.0 & 8.7 & 13.0 & 17.3 & 1.0 & & & & \\
\hline Kuwait & 1 & 0 & $\mathrm{p}$ & expats (own system) & $D, R-E$ & 12 & 1.6 & 2.1 & 10.7 & 32.5 & 75.8 & 2.5 & 12 & 0.7 & & \\
\hline Kyrgyz Republic & 1 &.. & a & $\begin{array}{l}\text { Firm size less } 15, \\
\text { managerial positions }\end{array}$ & $\mathrm{R}$ & .. & 13.0 & 13.0 & 13.0 & 13.0 & 13.0 & 5.6 & & & & \\
\hline Lao PDR & 1 &.. & ... & .. &.. & .. & 3.9 & 5.2 & 39.0 & 78.0 & 156.0 & 6.9 & & & & \\
\hline
\end{tabular}




\begin{tabular}{|c|c|c|c|c|c|c|c|c|c|c|c|c|c|c|c|c|}
\hline & \multicolumn{2}{|c|}{ Legal Base } & \multicolumn{2}{|r|}{ Coverage } & \multirow{2}{*}{\begin{tabular}{|c|} 
Eligible Contingencies \\
Dismissal/Redundancy \\
/Bankruptcy/lncapacity \\
IOld-Age/End-of- \\
service
\end{tabular}} & \multicolumn{7}{|c|}{ Defined Benefits for Redundancy } & \multicolumn{2}{|c|}{ End-of-Service Pay } & \multicolumn{2}{|c|}{ Defined Contribution } \\
\hline Country & Mandatory & $\begin{array}{l}\text { Collective } \\
\text { agree- } \\
\text { ments }\end{array}$ & Sectors & Excluded categories & & $\begin{array}{l}\text { Minimum } \\
\text { tenure } \\
\text { required } \\
\text { (months) }\end{array}$ & $\begin{array}{c}\text { Benefits } \\
\text { at } 9 \\
\text { months }\end{array}$ & $\begin{array}{l}\text { Benefits } \\
\text { at } 1 \text { year }\end{array}$ & $\begin{array}{l}\text { Benefits } \\
\text { at } 5 \text { yrs }\end{array}$ & $\begin{array}{l}\text { Benefit } \\
\text { at } 10 \mathrm{yrs}\end{array}$ & $\begin{array}{l}\text { Benefits } \\
\text { at } 20 \mathrm{yrs}\end{array}$ & $\begin{array}{l}\text { Generosity } \\
\text { index }\end{array}$ & $\begin{array}{l}\text { Minimum } \\
\text { tenure } \\
\text { required } \\
\text { (months) }\end{array}$ & $\begin{array}{c}\text { Generosity } \\
\text { index }\end{array}$ & $\begin{array}{l}\text { Minimum } \\
\text { tenure } \\
\text { required } \\
\text { (months) }\end{array}$ & $\begin{array}{c}\text { Contributio } \\
n \text { Rate } \\
\text { (\% of salary) }\end{array}$ \\
\hline Latvia & 1 & .. & .. & .. & $\mathrm{D}, \mathrm{R}, \mathrm{B}, \mathrm{I}, \mathrm{E}$ & ... & 4.3 & 4.3 & 8.7 & 13.0 & 17.3 & 2.5 & & & & \\
\hline Lebanon & 0 & .. & n.a. & n.a. & n.a. & n.a. & n.a. & n.a. & n.a. & n.a. & n.a. & 0.0 & & & & \\
\hline Lesotho & 1 & .. & ... & .. & $\mathrm{R}, .$. & 12 & 0.0 & 2.0 & 10.0 & 20.0 & 40.0 & 2.0 & & & & \\
\hline Liberia & 1 & .. & .. & .. & $\mathrm{R}, .$. & .. & 3.0 & 4.0 & 20.0 & 40.0 & 80.0 & 4.0 & & & & \\
\hline Lithuania & 1 & .. & .. & .. & $\mathrm{D}, \mathrm{R}, \mathrm{E}$ & .. & 4.3 & 8.7 & 17.3 & 21.7 & 26.0 & 4.8 & & & & \\
\hline Luxembourg & 1 & .. & $\mathrm{p}$ & none & $\mathrm{D}, \mathrm{R}$ & 60 & 0.0 & 0.0 & 4.3 & 8.7 & 26.0 & 0.6 & & & & \\
\hline Macedonia & 1 & .. & .. & .. & $\mathrm{D}, \mathrm{R}$ & .. & 4.3 & 4.3 & 8.7 & 13.0 & 21.7 & 2.5 & & & & \\
\hline Madagascar & 1 & 0 & .. & none & $\mathrm{D}, \mathrm{R}, \mathrm{B}$ & 6 & 0.0 & 1.7 & 8.3 & 16.7 & 26.0 & 1.7 & & & & \\
\hline Malawi & 1 & .. & a & Police, army & $\mathrm{D}, \mathrm{R}$ & 12 & 0.0 & 2.0 & 10.0 & 30.0 & 80.0 & 2.3 & & & & \\
\hline Malaysia & 1 & 0 & $\mathrm{a}$ & none & $\mathrm{D}, \mathrm{R}$ & 12 & 0.0 & 1.7 & 16.7 & 33.3 & 66.7 & 2.8 & & & & \\
\hline Maldives & 0 & 0 & n.a. & n.a. & n.a. & n.a. & n.a. & n.a. & n.a. & n.a. & n.a. & 0 & & & & \\
\hline Mali & 1 & 0 & & none & $\mathrm{D}, \mathrm{R}$ & 12 & 4.3 & 5.2 & 8.7 & 14.1 & 27.1 & 2.8 & & & & \\
\hline Marshall Islands & 0 & 0 & n.a. & n.a. & n.a. & n.a. & n.a. & n.a. & n.a. & n.a. & n.a. & 0 & & & & \\
\hline Mauritania & 1 & .. & .. & .. & $\mathrm{R}, .$. & & 0.8 & 1.1 & 5.4 & 11.9 & 27.1 & 1.1 & & & & \\
\hline Mauritius & 1 &.. & .. & .. & $\mathrm{R}, .$. & 12 & 0.0 & 0.4 & 4.3 & 14.3 & 42.9 & 0.9 & & & & \\
\hline Mexico & 1 & .. & $\mathrm{p}$ & none & $\mathrm{D}, \mathrm{R}$ & ... & 14.1 & 14.6 & 21.4 & 30.0 & 47.1 & 7.3 & & & & \\
\hline Micronesia & 0 & 0 & n.a. & n.a. & n.a. & n.a. & n.a. & n.a. & n.a. & n.a. & n.a. & 0.0 & & & & \\
\hline Moldova & 1 & .. & a & none & $\mathrm{D}, \mathrm{R}, \mathrm{B}, \mathrm{I}$ & .. & 9.6 & 9.6 & 13.6 & 18.6 & 28.7 & 4.7 & & & & \\
\hline Mongolia & 1 & .. &.. &.. & $\mathrm{D}, \mathrm{R}$ & .. & 4.3 & 4.3 & 4.3 & 4.3 & 4.3 & 1.9 & & & & \\
\hline Montenegro & 1 & .. & .. & .. & $\mathrm{R}, .$. & .. & 26.0 & 26.0 & 26.0 & 26.0 & 26.0 & 11.3 & & & & \\
\hline Morocco & 1 & 1 & $\mathrm{p}$ & $\begin{array}{l}\text { Firm size less 10, } \\
\text { domestic workers, }\end{array}$ & $\mathrm{D}, \mathrm{R}$ & 6 & 2.2 & 2.2 & 10.9 & 27.3 & 76.4 & 2.4 & & & & \\
\hline Mozambique & 1 & .. & .. & .. & $\mathrm{D}, \mathrm{R}$ & .. & 13.0 & 13.0 & 32.5 & 65.0 & 130.0 & 8.7 & & & & \\
\hline Namibia & 1 & .. & .. & .. & $\mathrm{R}, .$. & 12 & 0.0 & 1.0 & 5.0 & 10.0 & 20.0 & 1.0 & & & & \\
\hline Nepal & 1 & .. & $\mathrm{a}$ & Firm size less 10, & $\mathrm{R}$ & 6 & 0.0 & 4.3 & 21.4 & 42.9 & 85.7 & 4.3 & & & & \\
\hline Netherlands & 0 & 1 & n.a. & n.a. & n.a. & n.a. & n.a. & n.a. & n.a. & n.a. & n.a. & 0.0 & & & & \\
\hline New Zealand & 0 & 1 & .. & .. & $\mathrm{R}$ & 12 & 0.0 & 0.0 & 0.0 & 0.0 & 0.0 & 0.0 & & & & \\
\hline Nicaragua & 1 & & $\mathrm{a}$ & none & $\mathrm{D}, \mathrm{R}, \mathrm{E}$ & & 3.3 & 4.3 & 18.8 & 21.7 & 21.7 & 3.4 & & & & \\
\hline Niger & 1 & 1 & $\mathrm{p}$ & none & $\mathrm{D}, \mathrm{R}$ & 12 & 4.3 & 5.2 & 8.7 & 3.5 & 30.3 & 2.4 & & & & \\
\hline Nigeria & 1 &.. & $\mathrm{a}$ & $\begin{array}{c}\text { Domestic workers, air } \\
\text { workers, seafarers, } \\
\text { managerial positions, } \\
\text { army, police, etc. }\end{array}$ & $\mathrm{R}$ & .. & 1.7 & 2.3 & 11.4 & 22.9 & 45.8 & 2.3 & & & & \\
\hline Norway & 0 & 1 & .. & .. & 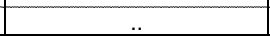 & . & 0.0 & 0.0 & 0.0 & 0.0 & 0.0 & 0.0 & & & & \\
\hline
\end{tabular}




\begin{tabular}{|c|c|c|c|c|c|c|c|c|c|c|c|c|c|c|c|c|}
\hline & \multicolumn{2}{|c|}{ Legal Base } & \multicolumn{2}{|r|}{ Coverage } & \multirow{2}{*}{\begin{tabular}{|c|} 
Eligible Contingencies \\
Dismissal/Redundancy \\
/Bankruptcy/Incapacity \\
IOld-Age/End-of- \\
service
\end{tabular}} & \multicolumn{7}{|c|}{ Defined Benefits for Redundancy } & \multicolumn{2}{|c|}{ End-of-Service Pay } & \multicolumn{2}{|c|}{ Defined Contribution } \\
\hline Country & Mandatory & $\begin{array}{l}\text { Collective } \\
\text { agree- } \\
\text { ments }\end{array}$ & Sectors & Excluded categories & & $\begin{array}{l}\text { Minimum } \\
\text { tenure } \\
\text { required } \\
\text { (months) }\end{array}$ & $\begin{array}{l}\text { Benefits } \\
\text { at } 9 \\
\text { months }\end{array}$ & $\begin{array}{l}\text { Benefits } \\
\text { at } 1 \text { year }\end{array}$ & $\begin{array}{l}\text { Benefits } \\
\text { at } 5 \text { yrs }\end{array}$ & $\begin{array}{l}\text { Benefit } \\
\text { at } 10 \mathrm{yrs}\end{array}$ & $\begin{array}{l}\text { Benefits } \\
\text { at } 20 \text { yrs }\end{array}$ & $\begin{array}{l}\text { Generosity } \\
\text { index }\end{array}$ & $\begin{array}{l}\text { Minimum } \\
\text { tenure } \\
\text { required } \\
\text { (months) }\end{array}$ & $\begin{array}{l}\text { Generosity } \\
\text { index }\end{array}$ & $\begin{array}{l}\text { Minimum } \\
\text { tenure } \\
\text { required } \\
\text { (months) }\end{array}$ & $\begin{array}{c}\text { Contributio } \\
n \text { Rate } \\
(\% \text { of salary) }\end{array}$ \\
\hline Oman & 1 & 0 & a & expats (own system) & $\mathrm{E}$ & 12 & n.a. & n.a. & n.a. & n.a. & n.a. & 0.0 & 12 & 17.3 & & \\
\hline Pakistan & 1 &.. & $\mathrm{a}$ & Firm size less 20 & $\mathrm{D}, \mathrm{R}, \mathrm{I}$ & .. & 3.2 & 4.3 & 21.4 & 42.9 & 85.7 & 4.3 & & & & \\
\hline Palau & 0 & 0 & n.a. & n.a. & n.a. & n.a. & n.a. & n.a. & n.a. & n.a. & n.a. & 0.0 & & & & \\
\hline Panama & 1 &.. & $\mathrm{p}$ & $\begin{array}{l}\text { Members of } \\
\text { cooperatives }\end{array}$ & $\mathrm{R}$ &.. & 3.0 & 4.0 & 19.0 & 34.0 & 44.0 & 3.7 & & & & \\
\hline Papua New Guinea & 1 &.. & .. & .. & $\mathrm{R}, .$. &.. & 1.3 & 1.7 & 8.7 & 17.3 & 34.7 & 1.7 & & & & \\
\hline Paraguay & 1 & .. & .. & .. & $\mathrm{R}, .$. & .. & 2.1 & 2.1 & 10.7 & 42.9 & 85.7 & 2.9 & & & & \\
\hline Peru & 1 & .. & $\mathrm{p}$ & none & $R-E$ & .. & 0.0 & 2.9 & 14.3 & 17.1 & 17.1 & 2.5 & & & .. & 8.33 \\
\hline Philippines & 1 & .. & $\mathrm{p}$ & none & $\mathrm{R}, \mathrm{I}, \mathrm{B}$ & 6 & 4.3 & 4.3 & 21.7 & 43.3 & 86.7 & 4.3 & & & & \\
\hline Poland & 0 & 1 & n.a. & n.a. & n.a. & n.a. & n.a. & n.a. & n.a. & n.a. & n.a. & 0.0 & & & & \\
\hline Portugal & 1 & .. & $\mathrm{a}$ & none & $\mathrm{D}, \mathrm{R}$ & 12 & 13.0 & 13.0 & 21.7 & 43.3 & 86.7 & 7.2 & & & & \\
\hline Puerto Rico & 0 & 1 & n.a. & n.a. & n.a. & n.a. & n.a. & n.a. & n.a. & n.a. & n.a. & 0.0 & & & & \\
\hline Qatar & 1 & 0 & ... & ... & $R-E$ & ... & 0.0 & 3.0 & 15.0 & 30.0 & 60.0 & 3.0 & 12 & 1.0 & & \\
\hline Romania & 0 & 1 & .. & .. & .. & .. & 4.3 & 4.3 & 4.3 & 4.3 & 4.3 & 1.9 & & & & \\
\hline Russian Federation & 1 &.. & a & $\begin{array}{l}\text { Army, managerial } \\
\text { positions }\end{array}$ & $\mathrm{D}, \mathrm{R}, \mathrm{B}$ & .. & 8.7 & 8.7 & 8.7 & 8.7 & 8.7 & 3.8 & & & & \\
\hline Rwanda & 1 & .. & ... & $\begin{array}{l}. . \\
\end{array}$ & $\mathrm{R}, .$. & .. & 0.0 & 4.3 & 8.7 & 13.0 & 21.7 & 2.5 & & & & \\
\hline Samoa & 0 & 0 & n.a. & n.a. & n.a. & n.a. & n.a. & n.a. & n.a. & n.a. & n.a. & 0.0 & & & & \\
\hline Sao Tome and Principe & 1 & .. & .. & .. & $\mathrm{R}, .$. & .. & 13.0 & 13.0 & 21.7 & 43.3 & 86.7 & 7.2 & & & & \\
\hline Saudi Arabia & 1 & 0 & $\mathrm{a}$ & expats (own system) & $D, R, B, I-E$ & .. & 2.2 & 2.2 & 10.8 & 32.5 & 75.8 & 2.5 & 12 & 0.9 & & \\
\hline Senegal & 1 & 1 & $\mathrm{p}$ & Seafarers & $\mathrm{D}, \mathrm{R}$ & 12 & 0.0 & 5.4 & 9.8 & 16.3 & 33.6 & 3.0 & & & & \\
\hline Serbia & 1 &.. &.. & .. & $\mathrm{R}, .$. & ... & 0.0 & 1.4 & 7.2 & 14.4 & 25.3 & 1.4 & & & & \\
\hline Seychelles & 1 &.. & .. & ... & $\mathrm{R}, .$. & ... & 1.3 & 1.7 & 8.6 & 17.1 & 34.3 & 1.7 & & & & \\
\hline Sierra Leone & 1 & .. & $\ldots$ & ... & $\mathrm{R}, \ldots$ & $\ldots$ & 4.0 & 4.4 & 28.0 & 72.0 & 180.0 & 5.7 & & & & \\
\hline Singapore & 0 & 1 & n.a. & n.a. & n.a. & n.a. & n.a. & n.a. & n.a. & n.a. & n.a. & 0.0 & & & & \\
\hline Slovak Republic & 1 & .. & $p$ & Seafarers & $R, I$ & ... & 8.7 & 8.7 & 13.0 & 13.0 & 13.0 & 4.2 & & & & \\
\hline Slovenia & 1 &.. & $\mathrm{p}$ & $\begin{array}{l}\text { Firm size less } 10, \\
\text { managerial positions }\end{array}$ & $D, R, I$ & 12 & 0.0 & 0.9 & 5.4 & 10.8 & 28.9 & 1.0 & & & & \\
\hline Solomon Islands & 1 & 0 & .. & .. & $\mathrm{R}, .$. &.. & 1.5 & 2.0 & 10.0 & 20.0 & 40.0 & 2.0 & & & & \\
\hline South Africa & 1 & 1 & a & $\begin{array}{l}\text { Army, state security, } \\
\text { seafarers }\end{array}$ & $\mathrm{R}, \mathrm{B}$ & 12 & 0.0 & 1.0 & 5.0 & 10.0 & 20.0 & 1.0 & & & & \\
\hline Spain & 1 & .. & $\mathrm{p}$ & none & $\mathrm{D}, \mathrm{R}, \mathrm{B}, \mathrm{I}$ & .. & 2.1 & 2.9 & 14.3 & 28.6 & 52.0 & 2.9 & & & & \\
\hline Sri Lanka & 1 & 0 & $\mathrm{p}$ & $\begin{array}{l}\text { Firm size less } 15 \\
\text { members of } \\
\text { cooperatives }\end{array}$ & $\mathrm{D}, \mathrm{R}, \mathrm{B}, \mathrm{I}, \mathrm{O}, \mathrm{E}$ & 60 & 8.1 & 10.8 & 54.2 & 97.5 & 169.0 & 10.5 & & & & \\
\hline St. Kitts and Nevis & 0 & .. & n.a. & n.a. & n.a. & n.a. & n.a. & n.a. & n.a. & n.a. & n.a. & 0.0 & & & & \\
\hline St. Lucia & 1 &.. & ... & ... & $\mathrm{R}, .$. & ... & 0.0 & 1.0 & 7.0 & 20.0 & 50.0 & 1.5 & & & & \\
\hline $\begin{array}{l}\text { St. Vincent and the } \\
\text { Grenadines }\end{array}$ & 1 & .. & .. & .. & $\mathrm{R}, .$. & .. & 0.0 & 0.0 & 10.0 & 20.0 & 50.0 & 1.3 & & & & \\
\hline
\end{tabular}




\begin{tabular}{|c|c|c|c|c|c|c|c|c|c|c|c|c|c|c|c|c|}
\hline & \multicolumn{2}{|c|}{ Legal Base } & \multicolumn{2}{|r|}{ Coverage } & \multirow{2}{*}{\begin{tabular}{|c|} 
Eligible Contingencies \\
Dismissal/Redundancy \\
/Bankruptcy/Incapacity \\
/Old-Age/End-of- \\
service
\end{tabular}} & \multicolumn{7}{|c|}{ Defined Benefits for Redundancy } & \multicolumn{2}{|c|}{ End-of-Service Pay } & \multicolumn{2}{|c|}{ Defined Contribution } \\
\hline Country & Mandatory & $\begin{array}{l}\text { Collective } \\
\text { agree- } \\
\text { ments }\end{array}$ & Sectors & Excluded categories & & $\begin{array}{l}\text { Minimum } \\
\text { tenure } \\
\text { required } \\
\text { (months) }\end{array}$ & $\begin{array}{l}\text { Benefits } \\
\text { at } 9 \\
\text { months }\end{array}$ & $\begin{array}{l}\text { Benefits } \\
\text { at } 1 \text { year }\end{array}$ & $\begin{array}{l}\text { Benefits } \\
\text { at } 5 \text { yrs }\end{array}$ & $\begin{array}{l}\text { Benefit } \\
\text { at } 10 \mathrm{yrs}\end{array}$ & $\begin{array}{l}\text { Benefits } \\
\text { at } 20 \mathrm{yrs}\end{array}$ & $\begin{array}{l}\text { Generosity } \\
\text { index }\end{array}$ & $\begin{array}{l}\text { Minimum } \\
\text { tenure } \\
\text { required } \\
\text { (months) }\end{array}$ & $\begin{array}{c}\text { Generosity } \\
\text { index }\end{array}$ & $\begin{array}{l}\text { Minimum } \\
\text { tenure } \\
\text { required } \\
\text { (months) }\end{array}$ & $\begin{array}{c}\text { Contributio } \\
n \text { Rate } \\
\text { (\% of salary) }\end{array}$ \\
\hline Sudan & 1 & .. & .. & .. & $\mathrm{R}, .$. & .. & 0.0 & 0.0 & 21.7 & 43.3 & 113.8 & 2.9 & & & & \\
\hline Suriname & 1 & .. & ... & .. & $\mathrm{R}, .$. & .. & 4.0 & 4.0 & 5.0 & 17.3 & 26.0 & 2.2 & & & & \\
\hline Swaziland & 1 &.. &.. & .. & $\mathrm{R}, .$. & .. & 0.0 & 0.0 & 8.0 & 18.0 & 38.0 & 1.1 & & & & \\
\hline Sweden & 0 & 1 & n.a. & n.a. & n.a. & n.a. & n.a. & n.a. & n.a. & n.a. & n.a. & 9.0 & & & & \\
\hline Switzerland & 1 & 1 & $\mathrm{p}$ & Firm size less 20 & $\mathrm{D}, \mathrm{R}, \mathrm{E}$ & 240 & 0.0 & 0.0 & 0.0 & 0.0 & 0.0 & 0.0 & & & & \\
\hline Syria & 1 & .. & $\mathrm{p}$ & Domestic workers & $\mathrm{D}, \mathrm{R}, \mathrm{E}$ & .. & 0.0 & 0.0 & 0.0 & 0.0 & 0.0 & 0.0 & & & & \\
\hline Taiwan & 1 & & .. & .. & $\mathrm{D}, \mathrm{R}$ & .. & 1.6 & 2.2 & 10.8 & 43.3 & 86.7 & 2.9 & & & & \\
\hline Tajikistan & 1 &.. & .. & .. & $\mathrm{R}, .$. & .. & 4.3 & 4.3 & 5.4 & 10.8 & 21.7 & 2.2 & & & & \\
\hline Tanzania & 1 & .. & a & Police, army & $\mathrm{D}, \mathrm{R}$ & 12 & 0.0 & 1.0 & 5.0 & 10.0 & 10.0 & 1.0 & & & & \\
\hline Thailand & 1 & 1 & $\mathrm{p}$ & $\begin{array}{l}\text { Agricultural workers, } \\
\text { domestic workers }\end{array}$ & $\mathrm{D}, \mathrm{R}$ & 4 & 5.0 & 15.0 & 30.0 & 50.0 & 50.0 & 8.7 & & & & \\
\hline Timor-Leste & 0 & 0 & n.a. & n.a. & n.a. & n.a. & n.a. & n.a. & n.a. & n.a. & n.a. & 0.0 & & & & \\
\hline Togo & 1 & 0 & .. & .. & $\mathrm{R}, .$. & .. & 1.0 & 1.3 & 6.5 & 14.1 & 31.4 & 1.3 & & & & \\
\hline Tonga & 0 & 0 & n.a. & n.a. & n.a. & n.a. & n.a. & n.a. & n.a. & n.a. & n.a. & 0.0 & & & & \\
\hline Trinidad and Tobago & 1 & .. & .. & .. & $\mathrm{R}, .$. & ... & 2.2 & 2.2 & 11.9 & 28.2 & 60.7 & 2.5 & & & & \\
\hline Tunisia & 1 & 1 & $\mathrm{p}$ & $\begin{array}{c}\text { Seafarers, domestic } \\
\text { workers }\end{array}$ & $\mathrm{D}, \mathrm{R}$ & 36 & 1.3 & 1.7 & 8.6 & 13.0 & 13.0 & 1.6 & & & & \\
\hline Turkey & 1 & 1 & $\mathrm{p}$ & $\begin{array}{c}\text { Firm size less } 30, \\
\text { agricultural and } \\
\text { domestic workers, } \\
\text { seafarers, managerial } \\
\text { positions, etc }\end{array}$ & $\mathrm{D}, \mathrm{R}, \mathrm{I}, \mathrm{O}$ & 12 & 0.0 & 4.3 & 21.7 & 43.3 & 86.7 & 4.3 & & & & \\
\hline Uganda & 1 &.. & a & Army & I,B & .. & 0.0 & 0.0 & 0.0 & 0.0 & 0.0 & 0.0 & & & & \\
\hline Ukraine & 1 & .. & .. & .. & $\mathrm{D}, \mathrm{R}, \mathrm{B}, \mathrm{I}$ & .. & 4.3 & 4.3 & 4.3 & 4.3 & 4.3 & 1.9 & & & & \\
\hline United Arab Emirates & 1 & 0 & $\mathrm{a}$ & expats (own system) & $D, R-E$ & 12 & 2.3 & 3.0 & 15.0 & 36.4 & 79.3 & 3.2 & 12 & 1.4 & & \\
\hline United Kingdom & 1 & 1 & $\mathrm{a}$ & Police, army, seafarers & $\mathrm{R}$ & 24 & 0.0 & 0.0 & 2.6 & 5.1 & 10.5 & 0.3 & & & & \\
\hline United States & 0 & 1 & n.a. & n.a. & n.a. & n.a. & n.a. & n.a. & n.a. & n.a. & n.a. & 0.0 & & & & \\
\hline Uruguay & 1 & .. & $\mathrm{a}$ & none & $\mathrm{D}, \mathrm{R}$ & ... & 5.2 & 5.2 & 26.0 & 31.2 & 31.2 & 4.5 & & & & \\
\hline Uzbekistan & 1 & .. &.. & .. & $\mathrm{D}, \mathrm{R}$ & .. & 13.0 & 13.0 & 13.0 & 13.0 & 13.0 & 5.6 & & & & \\
\hline Vanuatu & 1 & .. & .. & .. & $\mathrm{R}, .$. & .. & 0.0 & 4.3 & 21.7 & 43.3 & 43.3 & 4.3 & & & & \\
\hline Venezuela & 1 & .. & $\mathrm{p}$ & $\begin{array}{l}\text { Firm size less } 10 \\
\text { domestic workers }\end{array}$ & $\mathrm{D}, \mathrm{R}, \mathrm{O}$ & 3 & .. & .. & & & .. & .. & & & & \\
\hline Vietnam & 1 &.. & $\mathrm{p}$ & $\begin{array}{c}\text { Managerial positions, } \\
\text { members of } \\
\text { cooperatives, political } \\
\text { organisations }\end{array}$ & $D, R, E$ & 12 & 0.0 & 4.3 & 21.7 & 43.3 & 86.7 & 4.3 & & & & \\
\hline West Bank and Gaza & 1 & 0 & $\ldots$ & & $R, \ldots$ & $\ldots$ & 4.3 & 4.3 & 21.7 & 43.3 & 86.7 & 4.3 & & & & \\
\hline Yemen & 1 & 0 & $\mathrm{p}$ & $\begin{array}{l}\text { Agricultural and } \\
\text { domestic workers, }\end{array}$ & $\mathrm{D}, \mathrm{R}$ & .. & 3.3 & 4.3 & 21.7 & 43.3 & 86.7 & 4.3 & & & & \\
\hline
\end{tabular}




\begin{tabular}{|c|c|c|c|c|c|c|c|c|c|c|c|c|c|c|c|c|}
\hline & \multicolumn{2}{|c|}{ Legal Base } & \multicolumn{2}{|r|}{ Coverage } & \multirow{2}{*}{\begin{tabular}{|c|} 
Eligible Contingencies \\
Dismissal/Redundancy \\
/Bankruptcy/lncapacity \\
IOld-Age/End-of- \\
service
\end{tabular}} & \multicolumn{7}{|c|}{ Defined Benefits for Redundancy } & \multicolumn{2}{|c|}{ End-of-Service Pay } & \multicolumn{2}{|c|}{ Defined Contribution } \\
\hline Country & Mandatory & $\begin{array}{l}\text { Collective } \\
\text { agree- } \\
\text { ments }\end{array}$ & Sectors & Excluded categories & & $\begin{array}{l}\text { Minimum } \\
\text { tenure } \\
\text { required } \\
\text { (months) }\end{array}$ & $\begin{array}{l}\text { Benefits } \\
\text { at } 9 \\
\text { months }\end{array}$ & $\begin{array}{l}\text { Benefits } \\
\text { at } 1 \text { year }\end{array}$ & $\begin{array}{l}\text { Benefits } \\
\text { at } 5 \text { yrs }\end{array}$ & $\begin{array}{l}\text { Benefit } \\
\text { at } 10 \mathrm{yrs}\end{array}$ & $\begin{array}{l}\text { Benefits } \\
\text { at } 20 \mathrm{yrs}\end{array}$ & $\begin{array}{c}\text { Generosity } \\
\text { index }\end{array}$ & $\begin{array}{c}\text { Minimum } \\
\text { tenure } \\
\text { required } \\
\text { (months) }\end{array}$ & $\begin{array}{c}\text { Generosity } \\
\text { index }\end{array}$ & $\begin{array}{c}\text { Minimum } \\
\text { tenure } \\
\text { required } \\
\text { (months) }\end{array}$ & $\begin{array}{c}\text { Contributio } \\
n \text { Rate } \\
\text { (\% of salary) }\end{array}$ \\
\hline Zambia & 1 & 1 & a & $\begin{array}{l}\text { Domestic workers, } \\
\text { police, army, judiciary, } \\
\text { managerial positions }\end{array}$ & $\mathrm{D}, \mathrm{R}, \mathrm{I}$ & .. & 6.5 & 8.7 & 43.3 & 86.7 & 173.3 & 8.7 & & & & \\
\hline Zimbabwe & 1 & & $\mathrm{p}$ & none & $\mathrm{D}, \mathrm{R}$ & .. & 0.0 & 13.0 & 65.0 & 130.0 & 433.3 & 13.0 & & & & \\
\hline
\end{tabular}




\begin{tabular}{|c|c|c|c|c|c|c|c|c|c|c|c|c|c|c|c|c|c|}
\hline & & Funding & \& Taxation & & Reforms & & & Other Income & e support & & $\begin{array}{c}\text { Employment } \\
\text { Regulation } \\
\end{array}$ & & Country & Background & Variables & & \\
\hline Country & $\begin{array}{l}\text { State } \\
\text { contri- } \\
\text { bution }\end{array}$ & $\begin{array}{l}\text { Funding } \\
\text { method }\end{array}$ & $\begin{array}{c}\text { Taxation } \\
\text { of } \\
\text { benefits }\end{array}$ & $\begin{array}{l}\text { Guaran- } \\
\text { tee fund }\end{array}$ & Type of reform & $\begin{array}{l}\text { Year of } \\
\text { reform }\end{array}$ & $\begin{array}{c}\text { Type of } \\
\text { unemploy- } \\
\text { ment } \\
\text { benefit } \\
\text { system }\end{array}$ & $\begin{array}{l}\text { Unem- } \\
\text { ployment } \\
\text { benefit } \\
\text { generosity }\end{array}$ & $\begin{array}{l}\text { Type of } \\
\text { Pension } \\
\text { system }\end{array}$ & $\begin{array}{c}\text { Pension } \\
\text { benefit } \\
\text { gene- } \\
\text { rosity }\end{array}$ & $\begin{array}{c}\text { Redundancy } \\
\text { Notice Period } \\
\text { (weeks) }\end{array}$ & Region & Income level & $\begin{array}{l}\text { GDP per } \\
\text { capita } \\
\text { (Current } \\
\text { US\$, 2009) }\end{array}$ & $\begin{array}{l}\text { Unem- } \\
\text { ployment } \\
\text { rate, 2000- } \\
2008(\%)\end{array}$ & $\begin{array}{c}\text { Trade } \\
\text { Union } \\
\text { - Density } \\
\text { 2008-2009 }\end{array}$ & $\begin{array}{c}\text { Size of } \\
\text { informal } \\
\text { economy } \\
(\%)\end{array}$ \\
\hline Afghanistan & .. & I-C & & & & & none & n.a. & none & n.a. & 4.3 & Asia & \begin{tabular}{|l|l|} 
low income \\
\end{tabular} & 405 & .. & 0.00 & .. \\
\hline Albania & ... & I-C & fully & .. & no reform & n.a. & UI & 16 & PAYGO & .. & 11.6 & Transition & upper middle income & 3,808 &.. & .. & .. \\
\hline Algeria & .. & $E-F$ & .. & .. & \begin{tabular}{|l} 
Collective \\
Framework \\
Agreement - \\
Introduction of \\
severance pay \\
(non statutory)
\end{tabular} & 2006 & UI & 36 & PAYGO & 80 & 4.3 & MENA & upper middle income & 4,029 & 18.40 & .. &.. \\
\hline Angola & .. & I-C & .. & .. & I & ... & none & n.a. & Pilot & .. & 4.3 & Africa & lower middle income & 4,081 & .. & .. &.. \\
\hline Antigua and Barbuda & .. & I-C & .. & ... & ... &.. & UA & ... & PAYGO &.. & 3.4 & LAC & upper middle income & 12,920 & & & \\
\hline Argentina & .. & I-C & partially & .. & $\begin{array}{c}\text { Doubling of } \\
\text { severance pay for } \\
\text { non-regular } \\
\text { employees } \\
\end{array}$ & 2000 & UI & 10 & PAYGO & 62 & 7.2 & LAC & upper middle income & 7,626 & 13.50 & 36.70 & 25.4 \\
\hline Armenia & ... & I-C & fully & .. & No reform & n.a. & $\mathrm{UI}$ & 13 & PAYGO & & 8.7 & Transition & lower middle income & 2,826 & 28.70 & 56.20 & 46.3 \\
\hline Australia & Yes & I-C & partially & .. & No reform & n.a. & UA & 42 & mixed & 42 & 4.0 & OECD & high income & 42,279 & 5.50 & 19.10 & 15.3 \\
\hline Austria & No & E-A & partially & yes & $\begin{array}{c}\text { Move to individual } \\
\text { severance savings } \\
\text { accounts }\end{array}$ & 2003 & dual & 61 & PAYGO & 80 & 2.0 & OECD & high income & 45,561 & 4.30 & 35.10 & 10.2 \\
\hline Azerbaijan & .. & I-C & fully & ... & No reform & n.a. & $\mathrm{UI}$ & 9 & PAYGO & .. & 8.7 & Transition & upper middle income & 4,899 & 7.50 & .. & .. \\
\hline Bahamas & .. & $\mathrm{I}-\mathrm{C}$ & & .. & .. & .. & UI & .. & PAYGO & - & 0.0 & LAC & high income & & .. & & .. \\
\hline Bahrain & .. & $\mathrm{I}-\mathrm{C}$ & untaxed & .. & .. & .. & $\mathrm{UI}$ & .. & PAYGO & 79 & 4.3 & MENA & high income & 26,021 & .. & 0.00 & .. \\
\hline Bangladesh & No & I-C & .. & .. & $\begin{array}{l}\text { Decreased } \\
\text { generosity }\end{array}$ & 1985 & none & n.a. & PAYGO & .. & 4.3 & Asia & low income & 551 & 4.00 & .. &.. \\
\hline Belarus & ... & I-C & fully & .. & No reform & n.a. & $\mathrm{UI}$ & 8 & PAYGO & .. & 8.7 & Transition & upper middle income & 5,075 & .. & 79.70 & .. \\
\hline Belgium & n.a. & n.a. & n.a. & n.a. & n.a. & n.a. & $\mathrm{UI}$ & 65 & PAYGO & 42 & 6.0 & OECD & high income & 43,672 & 7.70 & 93.20 & 23.2 \\
\hline Belize & ... & I-C & ... &.. & & ... & none & n.a. & PAYGO & n.a. & 3.3 & LAC & lower middle income & 4,062 & .. & .. & .. \\
\hline Benin & ... & $\mathrm{I}-\mathrm{C}$ & ... & & No reform & n.a. & none & n.a. & PAYGO & ... & 4.3 & Africa & low income & 745 & .. & & .. \\
\hline Bhutan & n.a. & n.a. & n.a. & n.a. & n.a. & n.a. & none & n.a. & PAYGO & .. & 8.3 & Asia & lower middle income & 1,805 & & & \\
\hline Bolivia & .. & $\mathrm{I}-\mathrm{C}$ & & .. & No reform & n.a. & $\mathrm{UI}$ & .. & mixed & .. & & LAC & lower middle income & 1,758 & 7.80 & .. & 67.1 \\
\hline Bosnia and Herzegovina & .. & I-C & fully & .. & No reform & n.a. & UI & 6 & PAYGO & .. & 2.0 & Transition & upper middle income & 4,524 & 27.80 & .. & .. \\
\hline Botswana & .. & $\mathrm{I}-\mathrm{C}$ & .. & .. & Introduction of $\operatorname{sev} F$ & 1992 & none & n.a. & universal & & 4.9 & Africa & upper middle income & 6,063 & 19.00 & .. & .. \\
\hline Brazil & .. & E-A & .. & .. & \begin{tabular}{|c|} 
Contribution to \\
Unemployment \\
Guarantee Fund
\end{tabular} & 2001 & $\mathrm{UI}$ & 9 & PAYGO & .. & 4.3 & LAC & upper middle income & 8,121 & 9.00 & 20.90 & 39.8 \\
\hline Brunei Darussalam & n.a. & n.a. & n.a. & n.a. & n.a. & n.a. & none & n.a. & mixed & .. & 3.0 & Asia & high income & .. & & & \\
\hline Bulgaria & .. & I-C & fully & .. & $\begin{array}{c}\text { Introduction of sev } \\
\text { pay }\end{array}$ & 2001 & UI & 12 & mixed & 50 & 4.3 & Transition & upper middle income & 6,423 & 12.30 & .. & 36.9 \\
\hline Burkina Faso & .. & I-C & .. & .. & no reform & n.a. & none & ... & PAYGO & .. & 4.3 & Africa & low income & 517 &.. & .. & 38.4 \\
\hline Burundi &.. & $\mathrm{I}-\mathrm{C}$ &.. & .. & .. & .. & none & n.a. & PAYGO & .. & 8.7 & Africa & low income & 160 & .. & .. & .. \\
\hline Cambodia & .. & I-C & .. & & & .. & none & n.a. & none & .. & 7.9 & Asia & low income & 667 & .. & 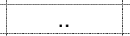 & .. \\
\hline Cameroon & .. & I-C & .. & .. & $\begin{array}{l}\text { Establish } \\
\text { calculation of } \\
\text { employees' } \\
\text { severance pay }\end{array}$ & 1993 & none & n.a. & PAYGO & .. & 6.5 & Africa & lower middle income & 1,136 & 7.50 & .. &.. \\
\hline Canada & Yes & $\mathrm{I}-\mathrm{C}$ & .. & .. & No reform & n.a. & UI & 52 & mixed & 45 & 7.0 & OECD & high income & 39,599 & 6.90 & 31.40 & 16.4 \\
\hline Cape Verde & .. & I-C & .. & & & & none & n.a. & PAYGO & & 6.4 & Africa & lower middle income & 3,064 & & & \\
\hline Central African Republic & .. & I-C & .. & .. & .. & .. & none & n.a. & PAYGO & .. & 4.3 & Africa & low income & 454 & .. & .. & .. \\
\hline Chad &.. & $\mathrm{I}-\mathrm{C}$ & 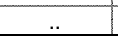 & 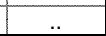 & .. & ... & none & n.a. & PAYGO & & 7.2 & Africa & low income & 610 & .. &. & \\
\hline
\end{tabular}




\begin{tabular}{|c|c|c|c|c|c|c|c|c|c|c|c|c|c|c|c|c|c|}
\hline \multirow[b]{2}{*}{ Country } & \multicolumn{4}{|c|}{ Funding \& Taxation } & \multicolumn{2}{|l|}{ Reforms } & \multicolumn{4}{|c|}{ Other Income support } & \multirow{2}{*}{\begin{tabular}{|c|}
$\begin{array}{c}\text { Employment } \\
\text { Regulation }\end{array}$ \\
Redundancy \\
Notice Period \\
(weeks)
\end{tabular}} & \multicolumn{6}{|c|}{ Country Background Variables } \\
\hline & $\begin{array}{l}\text { State } \\
\text { contri- } \\
\text { bution }\end{array}$ & $\begin{array}{r}\text { Funding } \\
\text { method }\end{array}$ & $\begin{array}{l}\text { Taxation } \\
\text { of } \\
\text { benefits }\end{array}$ & $\begin{array}{l}\text { Guaran- } \\
\text { tee fund }\end{array}$ & Type of reform & $\begin{array}{l}\text { Year of } \\
\text { reform }\end{array}$ & $\begin{array}{c}\text { Type of } \\
\text { unemploy- } \\
\text { ment } \\
\text { benefit } \\
\text { system }\end{array}$ & $\begin{array}{c}\text { Unem- } \\
\text { ployment } \\
\text { benefit } \\
\text { generosity }\end{array}$ & $\begin{array}{l}\text { Type of } \\
\text { Pension } \\
\text { system }\end{array}$ & $\begin{array}{c}\text { Pension } \\
\text { benefit } \\
\text { gene- } \\
\text { rosity }\end{array}$ & & Region & Income level & $\begin{array}{l}\text { GDP per } \\
\text { capita } \\
\text { (Current } \\
\text { US\$, 2009) }\end{array}$ & $\begin{array}{l}\text { Unem- } \\
\text { ployment } \\
\text { rate, 2000- } \\
2008(\%)\end{array}$ & $\begin{array}{c}\text { Trade } \\
\text { Union } \\
\text { Density } \\
\text { 2008-2009 }\end{array}$ & $\begin{array}{c}\text { Size of } \\
\text { informal } \\
\text { economy } \\
(\%)\end{array}$ \\
\hline Chile & Yes & E-A, E-F & .. & yes & $\begin{array}{c}\text { Increased access } \\
\text { to Solidarity Fund } \\
\text { for end-of-service } \\
\text { benefits for fixed } \\
\text { term contracts, } \\
\text { Increased benefits } \\
\text { level and quality } \\
\end{array}$ & 2009 & $\mathrm{UI}$ & 21 & mixed & 44 & 4.3 & OECD & upper middle income & 9,645 & 7.40 & 11.50 & 19.8 \\
\hline China & .. & I-C & partially & .. & Introduction of statu & 2008 & $\mathrm{UI}$ & 20 & mixed & 68 & 4.3 & Transition & lower middle income & 3,744 & .. & .. & 13.1 \\
\hline Colombia & No & E-A & partially & yes & $\begin{array}{c}\text { Intoduction of fully } \\
\text { funded severance } \\
\text { pay savings }\end{array}$ & 1990 & $\mathrm{UI}$ & .. & mixed & 50 & 0.0 & LAC & upper middle income & 5,125 & 13.00 & 28.70 & 39.1 \\
\hline Comoros & & I-C & .. & ... & & & none & n.a. & none & & 13.0 & Africa & low income & 833 & & & \\
\hline Congo, Dem. Rep. & & I-C &.. & .. & & & none & n.a. & PAYGO & & 10.3 & Africa & low income & 160 & & & \\
\hline Congo, Rep. & & I-C &.. & .. & & & none & n.a. & PAYGO & & 4.3 & Africa & lower middle income & 2,601 & & & \\
\hline Costa Rica & .. & I-C &.. & .. & No reform & n.a. & UI & .. & mixed & 89 & 4.3 & LAC & upper middle income & 6,385 & 5.90 & .. & .. \\
\hline Cote d'Ivoire & .. & I-C & .. & .. & \begin{tabular}{|c|} 
Introduction of sev \\
pay
\end{tabular} & 1996 & none & n.a. & PAYGO & .. & 5.8 & Africa & lower middle income & 1,105 & .. & .. & .. \\
\hline Croatia & ... & I-C & fully & .. & \begin{tabular}{|l|} 
No reform \\
\end{tabular} & n.a. & dual & 11 & mixed & 38 & 7.9 & Transition & high income & 14,222 & 13.00 & .. & 33.4 \\
\hline Cyprus & n.a. & n.a. & n.a. & yes & & 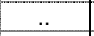 & $\mathrm{UI}$ & .. & PAYGO & & 5.7 & OECD & high income & 31,410 & $?$ & .. & \\
\hline Czech Republic & Yes & I-C & fully & & No reform & n.a. & $\mathrm{UI}$ & 33 & PAYGO & 50 & 8.7 & OECD & high income & 18,139 & 7.22 & 20.80 & 19.1 \\
\hline Denmark & Yes & I-C & .. & & $\begin{array}{c}\text { Establish benefits } \\
\text { for } \\
\text { White-Collar } \\
\text { workers }\end{array}$ & 1996 & $\mathrm{UI}$ & 68 & mixed & 80 & 0.0 & OECD & high income & 55,992 & 4.63 & 99.20 & 18.2 \\
\hline Djibouti & n.a. & n.a. & n.a. & n.a. & & .. & none & n.a. & PAYGO & & 4.3 & Africa & lower middle income & 1,213 &.. & .. & .. \\
\hline Dominica & ... & I-C & .. & s & & .. & none & n.a. & PAYGO & .. & 5.8 & LAC & upper middle income & 5,132 &.. &.. & .. \\
\hline Dominican Rep. &.. & I-C &.. &.. & No reform & n.a. & none & n.a. & mixed & 53 & 4.0 & LAC & upper middle income & 4,637 & 16.00 &.. & 32.1 \\
\hline Ecuador & .. & I-C &.. &.. & $\begin{array}{l}\text { Increase in } \\
\text { severance }\end{array}$ & 1991 & UI & .. & mixed & .. & 4.3 & LAC & lower middle income & 4,202 & 8.70 & .. & 34.4 \\
\hline Egypt, Arab Rep. & .. & I-C & untaxed & .. & $\begin{array}{c}\text { Unfinshed years to } \\
\text { be considered as } \\
\text { full years when } \\
\text { calculating tenure }\end{array}$ & 2003 & UI & 7 & PAYGO & .. & 10.1 & MENA & lower middle income & 2,270 & 9.90 & 26.10 & 35.1 \\
\hline El Salvador & ... & I-C & ... & $\ldots$ & \begin{tabular}{|l|}
.. \\
\end{tabular} &... & UI & n.a. & PAYGO & & 0.0 & LAC & lower middle income & 3,424 & $\ldots$ & $\therefore$. & ... \\
\hline Equatorial Guinea & .. & $\mathrm{I}-\mathrm{C}$ & .. & .. & .. & ... & none & n.a. & none & n.a. & 4.3 & Africa & high income & 15,397 &.. & .. & .. \\
\hline Eritrea & .. & I-C & & ... & ... & ... & none & n.a. & none & n.a. & 3.1 & Africa & low income & 369 & & & .. \\
\hline Estonia & .. & I-C & fully & yes & n.a. & n.a. & dual & .. & mixed & 52 & 8.6 & OECD & high income & 14,238 & 8.90 & 7.60 & .. \\
\hline Ethiopia & .. & I-C & .. & .. & $\begin{array}{l}\text { Introduction of } \\
\text { severance pay }\end{array}$ & 2003 & none & .. & PAYGO &.$\cdot$ & 10.1 & Africa & low income & 344 & 5.00 & 12.90 & .. \\
\hline Fiji & $\cdot \cdot$ & I-C & .. & .. & 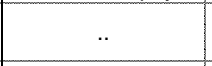 &.. & none & n.a. & $\begin{array}{c}\text { Provident } \\
\text { fund }\end{array}$ &.$\cdot$ & 4.3 & Asia & upper middle income & 3,326 & $\cdot \cdot$ & .. & $\cdot \cdot$ \\
\hline Finland & Yes & I-C & .. & yes & No reform & n.a. & dual & 60 & PAYGO & 56 & 10.1 & OECD & high income & 44,581 & 8.30 & 68.00 & 18.3 \\
\hline France & Yes & I-C & .. & .. & $\begin{array}{c}\text { Statutory min } \\
\text { payment and extra } \\
\text { benefit for } \\
\text { employees with } \\
\text { more than10 years } \\
\text { tenure } \\
\end{array}$ & 2008 & dual & 67 & PAYGO & 53 & 7.2 & OECD & high income & 41,051 & 8.30 & 7.90 & 15.3 \\
\hline Gabon & .. & I-C & & & & & none & n.a. & PAYGO & & 10.4 & Africa & upper middle income & 7,502 & .. & .. & \\
\hline Gambia & n.a. & n.a. & n.a. & n.a. & n.a. & n.a. & none & n.a. & PAYGO & & 26.0 & Africa & low income & 430 & & & \\
\hline
\end{tabular}




\begin{tabular}{|c|c|c|c|c|c|c|c|c|c|c|c|c|c|c|c|c|c|}
\hline \multirow[b]{2}{*}{ Country } & \multicolumn{4}{|c|}{ Funding \& Taxation } & \multicolumn{2}{|l|}{ Reforms } & \multicolumn{4}{|c|}{ Other Income support } & \multirow{2}{*}{\begin{tabular}{|c|}
$\begin{array}{c}\text { Employment } \\
\text { Regulation }\end{array}$ \\
$\begin{array}{c}\text { Redundancy } \\
\text { Notice Period } \\
\text { (weeks) }\end{array}$ \\
\end{tabular}} & \multicolumn{6}{|c|}{ Country Background Variables } \\
\hline & $\begin{array}{l}\text { State } \\
\text { contri- } \\
\text { bution }\end{array}$ & $\begin{array}{l}\text { Funding } \\
\text { method }\end{array}$ & $\begin{array}{c}\text { Taxation } \\
\text { of } \\
\text { benefits }\end{array}$ & $\begin{array}{l}\text { Guaran- } \\
\text { tee fund }\end{array}$ & Type of reform & $\begin{array}{l}\text { Year of } \\
\text { reform }\end{array}$ & $\begin{array}{c}\text { Type of } \\
\text { unemploy- } \\
\text { ment } \\
\text { benefit } \\
\text { system }\end{array}$ & $\begin{array}{l}\text { Unem- } \\
\text { ployment } \\
\text { benefit } \\
\text { generosity }\end{array}$ & $\begin{array}{l}\text { Type of } \\
\text { Pension } \\
\text { system }\end{array}$ & $\begin{array}{c}\text { Pension } \\
\text { benefit } \\
\text { gene- } \\
\text { rosity }\end{array}$ & & Region & Income level & $\begin{array}{l}\text { GDP per } \\
\text { capita } \\
\text { (Current } \\
\text { US\$, 2009) }\end{array}$ & $\begin{array}{l}\text { Unem- } \\
\text { ployment } \\
\text { rate, 2000- } \\
2008(\%)\end{array}$ & $\begin{array}{c}\text { Trade } \\
\text { Union } \\
- \text { Density } \\
\text { 2008-2009 }\end{array}$ & $\begin{array}{c}\text { Size of } \\
\text { informal } \\
\text { economy } \\
(\%)\end{array}$ \\
\hline Georgia & .. & I-C & fully & & & & UI & 6 & PAYGO & & 0.0 & Transition & lower middle income & 2,449 & 12.80 & 40.70 & 67.3 \\
\hline Germany & Yes & I-C & fully & no & No reform & n.a. & dual & 64 & PAYGO & 43 & 10.0 & OECD & high income & 40,670 & 9.20 & 19.90 & 16.3 \\
\hline Ghana & ... & I-C & .. & .. & No reform & n.a. & none & n.a. & mixed &.. & 3.6 & Africa & low income & 1,098 & ... & 70.00 & 38.4 \\
\hline Greece & Yes & I-C & partially & .. & $\begin{array}{c}\text { Increase in } \\
\text { severance pay for } \\
\text { blue color workers }\end{array}$ & 2007 & $\mathrm{UI}$ & 33 & PAYGO & 96 & 0.0 & OECD & high income & 29,240 & 9.50 & 30.60 & 28.6 \\
\hline Grenada & ... & $\mathrm{I}-\mathrm{C}$ & & .. & & & none & n.a. & PAYGO &... & 7.2 & LAC & upper middle income & 6,029 & & & .. \\
\hline Guatemala & .. & I-C & .. & .. & No reform & n.a. & UI & .. & PAYGO & .. & 0.0 & LAC & lower middle income & 2,661 & 2.40 & 12.90 & .. \\
\hline Guinea & .. & I-C & .. & .. & .. & .. & none & n.a. & PAYGO & .. & 2.1 & Africa & low income & 497 & .. & .. &.. \\
\hline Guinea-Bissau & ... & I-C & ... & .. & ... & .. & none & n.a. & none & ... & 0.0 & Africa & low income & 519 & .. & .. &.. \\
\hline Guyana & .. & $\mathrm{I}-\mathrm{C}$ & ... & ... & ... & .. & none & n.a. & PAYGO & ... & 4.3 & LAC & lower middle income & 1,518 & .. & .. & .. \\
\hline Haiti & n.a. & n.a. & n.a. & n.a. & n.a. & n.a. & none & n.a. & none & n.a. & 10.1 & LAC & low income & 646 &.. & .. & .. \\
\hline Honduras &.. & $\mathrm{I}-\mathrm{C}$ & 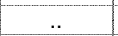 & 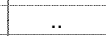 & No reform & n.a. & UI & & PAYGO & & 7.2 & LAC & lower middle income & 1,918 & 4.10 & & \\
\hline Hong Kong & .. & I-C & ... & .. & No reform & n.a. & UA & 32 & mixed & 38 & 4.3 & Asia & high income & 30,863 & 5.60 & 21.50 & 16.6 \\
\hline Hungary & Yes & I-C & fully & yes & $\begin{array}{l}\text { Intoduction of } \\
\text { wage guatantee } \\
\text { fund }\end{array}$ & 1994 & UI & 48 & mixed & 77 & 6.2 & OECD & high income & 12,868 & 6.60 & 19.90 & 25.1 \\
\hline Iceland & .. & n.a. & & & & & $\mathrm{UI}$ & 57 & mixed & & 10.1 & OECD & high income & 38,029 & & .. & \\
\hline India & No & I-C & partially &.. & No reform & n.a. & $\mathrm{UI}$ & .. & mixed & 40 & 4.3 & Asia & lower middle income & 1,134 & 4.30 & .. & 23.1 \\
\hline Indonesia & .. & I-C & .. & .. & Pending Reform... & $\begin{array}{l}2000- \\
2007- \\
2011\end{array}$ & none & n.a. & mixed & 15 & 0.0 & Asia & lower middle income & 2,349 & 9.10 & .. & 19.4 \\
\hline Iran & ... & I-C & & & No reform & n.a. & $\mathrm{UI}$ & 47 & PAYGO &.. & 0.0 & Asia & upper middle income & 4,540 & 10.90 & .. & .. \\
\hline Iraq & n.a. & n.a. & n.a. & n.a. & & & none & n.a. & PAYGO & & 0.0 & MENA & lower middle income & 2,090 & & & \\
\hline Ireland & Yes & $\mathrm{I}-\mathrm{C}$ & partially & 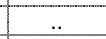 & No reform & n.a. & dual & 50 & mixed & 34 & 4.0 & $\mathrm{OECD}$ & high income & 51,049 & 4.50 & 31.50 & 15.8 \\
\hline Israel & .. & I-C & partially & yes & No reform & n.a. & $\mathrm{UI}$ & .. & PAYGO & .. & 4.3 & OECD & high income & 26,256 & 8.90 & .. & 21.9 \\
\hline Italy & $\begin{array}{c}\text { tax } \\
\text { incentiv } \\
\text { es }\end{array}$ & E-A, E-F & partially & yes & $\begin{array}{l}\text { Option to switch to } \\
\text { funded occup. } \\
\text { pension plan }\end{array}$ & 2007 & UI & 37 & PAYGO & 68 & 8.7 & OECD & high income & 35,084 & 8.10 & 97.10 & 27 \\
\hline Jamaica & & I-C & .. & .. & No reform & n.a. & none & n.a. & PAYGO & & 4.0 & LAC & upper middle income & 4,471 & 11.90 & & 36.4 \\
\hline Japan & Yes & I-B & .. & .. & No reform & n.a. & UI & 45 & PAYGO & 34 & 4.3 & OECD & high income & 39,738 & 4.60 & 18.00 & 11.3 \\
\hline Jordan & .. & I-C & .. & .. & $\begin{array}{l}\text { Change in service } \\
\text { period for } \\
\text { calculation of sev } \\
\text { pay benefits }\end{array}$ & 2010 & none & n.a. & PAYGO & 68 & 4.3 & MENA & lower middle income & 4,216 & .. & .. & 19.4 \\
\hline Kazakhstan & .. & I-C & fully & .. & No reform & n.a. & $\mathrm{UI}$ & .. & mixed & .. & 4.3 & Transition & upper middle income & 7,257 & 8.30 & .. & 43.2 \\
\hline Kenya & .. & I-C & .. & .. & No reform & n.a. & none & n.a. & $\begin{array}{l}\text { Provident } \\
\text { fund }\end{array}$ & .. & 4.3 & Africa & low income & 738 & .. & 35.50 & 34.3 \\
\hline Kiribati & n.a. & n.a. & n.a. & n.a. & n.a. & n.a. & none & n.a. & $\begin{array}{l}\text { Provident } \\
\text { fund }\end{array}$ & n.a. & 4.3 & Asia & lower middle income & 1,306 &.. &.. &.. \\
\hline Korea & No & I-B, E-A & partially & yes & $\begin{array}{l}\text { Option to switch to } \\
\text { funded occup. } \\
\text { pension plan }\end{array}$ & 2005 & $\mathrm{UI}$ & 31 & PAYGO & 42 & 4.3 & OECD & high income & 17,078 & 3.60 & 10.00 & 27.5 \\
\hline Kosovo & .. & $\mathrm{I}-\mathrm{C}$ & &.. & \begin{tabular}{|c|} 
\\
\end{tabular} & ... & none & n.a. & funded & .. & 13.0 & Transition & lower middle income & 2,985 & .. &.. &.. \\
\hline Kuwait & No & $\mathrm{I}-\mathrm{C}$ & untaxed & no & & & none & n.a. & PAYGO &.. & 13.0 & MENA & high income & 54,260 & .. & 0.00 & .. \\
\hline Kyrgyz Republic & .. & I-C & fully & & $\begin{array}{l}\text { Introduction of } \\
\text { redundancy } \\
\text { payment }\end{array}$ & 2004 & UI & 6 & PAYGO & .. & 4.3 & Transition & low income & 860 & 8.80 & .. & 39.8 \\
\hline Lao PDR &.. & I-C & & & & & none & n.a. & PAYGO & n.a. & 6.4 & Asia & low income & 940 & &.. &.. \\
\hline
\end{tabular}




\begin{tabular}{|c|c|c|c|c|c|c|c|c|c|c|c|c|c|c|c|c|c|}
\hline \multirow[b]{2}{*}{ Country } & \multicolumn{4}{|c|}{ Funding \& Taxation } & \multicolumn{2}{|l|}{ Reforms } & \multicolumn{4}{|c|}{ Other Income support } & \multirow{3}{*}{\begin{tabular}{|c|}
$\begin{array}{c}\text { Employment } \\
\text { Regulation }\end{array}$ \\
$\begin{array}{c}\text { Redundancy } \\
\text { Notice Period } \\
\text { (weeks) }\end{array}$ \\
1.0
\end{tabular}} & \multicolumn{6}{|c|}{ Country Background Variables } \\
\hline & $\begin{array}{l}\text { State } \\
\text { contri- } \\
\text { bution }\end{array}$ & $\begin{array}{c}\text { Funding } \\
\text { method }\end{array}$ & $\begin{array}{c}\text { Taxation } \\
\text { of } \\
\text { benefits }\end{array}$ & $\begin{array}{l}\text { Guaran- } \\
\text { tee fund }\end{array}$ & Type of reform & $\begin{array}{l}\text { Year of } \\
\text { reform }\end{array}$ & $\begin{array}{c}\text { Type of } \\
\text { unemploy- } \\
\text { ment } \\
\text { benefit } \\
\text { system }\end{array}$ & $\begin{array}{c}\text { Unem- } \\
\text { ployment } \\
\text { benefit } \\
\text { generosity }\end{array}$ & $\begin{array}{c}\text { Type of } \\
\text { Pension } \\
\text { system }\end{array}$ & $\begin{array}{c}\text { Pension } \\
\text { benefit } \\
\text { gene- } \\
\text { rosity }\end{array}$ & & Region & Income level & $\begin{array}{l}\text { GDP per } \\
\text { capita } \\
\text { (Current } \\
\text { US\$, 2009) }\end{array}$ & $\begin{array}{l}\text { Unem- } \\
\text { ployment } \\
\text { rate, 2000- } \\
2008(\%)\end{array}$ & $\begin{array}{c}\text { Trade } \\
\text { Union } \\
\text { - Density } \\
\text { 2008-2009 }\end{array}$ & $\begin{array}{c}\text { Size of } \\
\text { informal } \\
\text { economy } \\
(\%)\end{array}$ \\
\hline Latvia & .. & I-C & fully & ... & No reform & n.a. & UI & 12 & mixed & 58 & & Transition & high income & 11,616 & 9.90 & 13.00 & 39.9 \\
\hline Lebanon & n.a. & n.a. & n.a. & n.a. & No reform & n.a. & none & n.a. & none & n.a. & 8.7 & MENA & upper middle income & 8,175 & 8.50 & .. & 34.1 \\
\hline Lesotho & .. & I-C & & .. & & .. & none & n.a. & PAYGO & .. & 4.3 & Africa & lower middle income & 764 & & .. & \\
\hline Liberia & .. & $\mathrm{I}-\mathrm{C}$ & & .. & & .. & none & n.a. & none & n.a. & 4.3 & Africa & low income & 222 & & & \\
\hline Lithuania & .. & I-C & fully & .. & No reform & n.a. & $\mathrm{UI}$ & 6 & mixed & 53 & 8.7 & Transition & upper middle income & 11,141 & 10.60 & 10.00 & 30.3 \\
\hline Luxembourg & .. & I-C & .. & .. & No reform & n.a. & $\mathrm{UI}$ & 87 & PAYGO & 88 & 17.3 & OECD & high income & 105,044 & 4.60 & 43.60 & .. \\
\hline Macedonia & .. & I-C & fully & .. & $\begin{array}{c}\text { Severance pay } \\
\text { formula slightly } \\
\text { modified }\end{array}$ & 2005 & $\mathrm{UI}$ & 13 & mixed & .. & 4.3 & Transition & upper middle income & 4,515 & 34.80 & .. & .. \\
\hline Madagascar & .. & I-C & ... & .. & \begin{tabular}{|l|} 
No reform \\
\end{tabular} & n.a. & none & n.a. & PAYGO & .. & 3.4 & Africa & low income & 461 & 5.60 & .. & 39.6 \\
\hline Malawi & .. & I-C & & .. & $\begin{array}{c}\text { Right to severance } \\
\text { pay not applicable } \\
\text { in case of fair } \\
\text { dismissal related to } \\
\text { employee's } \\
\text { conduct }\end{array}$ & 2000 & none & n.a. & none & n.a. & 4.3 & Africa & low income & 326 & .. & 20.60 & 40.3 \\
\hline Malaysia & No & $\mathrm{I}-\mathrm{C}$ & partially & .. & No reform & n.a. & none & n.a. & $\begin{array}{c}\text { Provident } \\
\text { fund }\end{array}$ & 32 & 6.7 & Asia & upper middle income & 7,030 & 3.40 & 10.30 & 31.1 \\
\hline Maldives & n.a. & n.a. & n.a. & n.a. & n.a. & n.a. & none & n.a. & PAYGO & n.a. & 5.8 & Asia & lower middle income & 4,760 & & 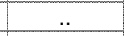 & \\
\hline Mali & ... & I-C & & ... & No reform & n.a. & none & n.a. & PAYGO & n.a. & 4.3 & Africa & low income & 691 & 8.80 & $\ddot{*}$ & 41 \\
\hline Marshall Islands & n.a. & n.a. & n.a. & n.a. & n.a. & n.a. & none & n.a. & PAYGO & n.a. & 0.0 & Asia & lower middle income & 2,504 & & .. & \\
\hline Mauritania & .. & I-C & 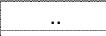 & .. & .. & .. & none & n.a. & PAYGO & .. & 4.3 & Africa & low income & 921 & .. & .. & .. \\
\hline Mauritius & .. & I-C & & .. & & & none & n.a. & mixed & ... & 4.3 & Africa & upper middle income & 6,735 & & & \\
\hline Mexico & ... & I-C & partially & ... & No reform & n.a. & none & n.a. & funded & 36 & 0.0 & OECD & upper middle income & 8,144 & 3.20 & 17.00 & 30.1 \\
\hline Micronesia & n.a. & n.a. & n.a. & n.a. & n.a. & n.a. & none & n.a. & PAYGO & n.a. & 0.0 & Asia & lower middle income & 2,476 & & & \\
\hline Moldova & .. & I-C & fully & .. & $\begin{array}{l}\text { Sev pay only for } \\
\text { dismissals based } \\
\text { on the worker's } \\
\text { capacity, state of } \\
\text { health and } \\
\text { insufficient } \\
\text { qualifications }\end{array}$ & 2003 & $\mathrm{UI}$ & 15 & PAYGO & .. & 8.7 & Transition & lower middle income & 1,516 & 6.90 & 40.00 & \\
\hline Mongolia & .. & I-C & .. &.. & No reform & n.a. & none & n.a. & PAYGO &.. & 4.3 & Transition & lower middle income & 1,573 & 3.50 & & 18.4 \\
\hline Montenegro & .. & I-C & .. & .. & $x^{2}$ & $\ldots$ & $\mathrm{UI}$ & $\ldots$ & PAYGO & .. & 2.1 & Transition & upper middle income & 6,635 & & & \\
\hline Morocco & No & $E-F$ & .. & .. & $\begin{array}{l}\text { Increase in } \\
\text { generosity }\end{array}$ & 2003 & none & n.a. & PAYGO & 70 & 7.2 & MENA & lower middle income & 2,911 & 11.10 & .. & 36.4 \\
\hline Mozambique & .. & I-C & & .. & No reform & n.a. & none & n.a. & PAYGO & .. & 4.3 & Africa & low income & 428 & $\cdots$ & & 40.3 \\
\hline Namibia & .. & I-C & & .. & & .. & none & n.a. & PAYGO & & 4.3 & Africa & upper middle income & 4,267 & & & \\
\hline Nepal & .. & $\mathrm{I}-\mathrm{C}$ & .. & .. & \begin{tabular}{|c|} 
Introduction of \\
lump-sum payment \\
in case of \\
redundancy
\end{tabular} & 1991 & none & n.a. & $\begin{array}{l}\text { Provident } \\
\text { fund }\end{array}$ & .. & 4.3 & Asia & low income & 427 & .. & .. & .. \\
\hline Netherlands & n.a. & n.a. & n.a. & n.a. & n.a. & n.a. & dual & 71 & mixed & 88 & 8.7 & OECD & high income & 47,917 & 3.70 & 20.50 & 13 \\
\hline New Zealand & Yes & I-C & fully & .. & No reform & n.a. & UA & 38 & universal & 39 & 0.0 & OECD & high income & 29,352 & 4.60 & 20.80 & 12.7 \\
\hline Nicaragua & .. & $\mathrm{I}-\mathrm{C}$ & & .. & No reform & n.a. & none & n.a. & PAYGO & ... & 0.0 & LAC & lower middle income & 1,097 & 6.00 & 4.10 & \\
\hline Niger &.. & $\mathrm{I}-\mathrm{C}$ &.. &.. & No reform & n.a. & none & n.a. & PAYGO &.. & 4.3 & Africa & low income & 352 &.. & .. & .. \\
\hline Nigeria & .. & I-C & .. & .. & No reform & n.a. & none & n.a. & funded & .. & 4.0 & Africa & lower middle income & 1,118 & .. & .. & 57.9 \\
\hline Norway &.. & I-C & .. & .. & No reform & n.a. & $\mathrm{UI}$ & 72 & PAYGO & 59 & 8.7 & OECD & high income & 79,089 & 3.70 & 52.90 & 19.1 \\
\hline
\end{tabular}




\begin{tabular}{|c|c|c|c|c|c|c|c|c|c|c|c|c|c|c|c|c|c|}
\hline \multirow[b]{2}{*}{ Country } & \multicolumn{4}{|c|}{ Funding \& Taxation } & \multicolumn{2}{|l|}{ Reforms } & \multicolumn{4}{|c|}{ Other Income support } & \multirow{3}{*}{\begin{tabular}{|c|}
$\begin{array}{c}\text { Employment } \\
\text { Regulation }\end{array}$ \\
$\begin{array}{c}\text { Redundancy } \\
\text { Notice Period } \\
\text { (weeks) }\end{array}$ \\
4.3 \\
\end{tabular}} & \multicolumn{6}{|c|}{ Country Background Variables } \\
\hline & $\begin{array}{l}\text { State } \\
\text { contri- } \\
\text { bution }\end{array}$ & $\begin{array}{l}\text { Funding } \\
\text { method }\end{array}$ & $\begin{array}{c}\text { Taxation } \\
\text { of } \\
\text { benefits }\end{array}$ & $\begin{array}{l}\text { Guaran- } \\
\text { tee fund }\end{array}$ & Type of reform & $\begin{array}{l}\text { Year of } \\
\text { reform }\end{array}$ & $\begin{array}{c}\text { Type of } \\
\text { unemploy- } \\
\text { ment } \\
\text { benefit } \\
\text { system }\end{array}$ & $\begin{array}{c}\text { Unem- } \\
\text { ployment } \\
\text { benefit } \\
\text { generosity }\end{array}$ & $\begin{array}{l}\text { Type of } \\
\text { Pension } \\
\text { system }\end{array}$ & $\begin{array}{c}\text { Pension } \\
\text { benefit } \\
\text { gene- } \\
\text { rosity }\end{array}$ & & Region & Income level & $\begin{array}{l}\text { GDP per } \\
\text { capita } \\
\text { (Current } \\
\text { US\$, 2009) }\end{array}$ & $\begin{array}{l}\text { Unem- } \\
\text { ployment } \\
\text { rate, 2000- } \\
2008(\%)\end{array}$ & $\begin{array}{c}\text { Trade } \\
\text { Union } \\
- \text { Density } \\
\text { 2008-2009 }\end{array}$ & $\begin{array}{c}\text { Size of } \\
\text { informal } \\
\text { economy } \\
(\%)\end{array}$ \\
\hline Oman & No & $\mathrm{I}-\mathrm{C}$ & untaxed & no & & .. & UI & n.a. & PAYGO & .. & & MENA & high income & 16,207 & & 0.00 & \\
\hline Pakistan & .. & I-C & & .. & No reform & n.a. & none & n.a. & PAYGO & .. & 4.3 & Asia & lower middle income & 955 & 7.10 & 15.70 & 36.8 \\
\hline Palau & n.a. & n.a. & n.a. & n.a. & n.a. & n.a. & none & n.a. & PAYGO & n.a. & 0.0 & Asia & upper middle income & 8,074 & & .. & .. \\
\hline Panama & .. & I-C & partially & .. & No reform & n.a. & $\mathrm{UI}$ & .. & mixed & .. & 0.0 & LAC & upper middle income & 7,155 & 11.10 & .. & 64.1 \\
\hline Papua New Guinea & .. & $\mathrm{I}-\mathrm{C}$ & .. & .. & .. & .. & none & n.a. & funded & n.a. & 3.3 & Asia & lower middle income & 1,172 & .. & .. & ... \\
\hline Paraguay & .. & $\mathrm{I}-\mathrm{C}$ & .. & .. & .. & .. & $\mathrm{UI}$ & .. & PAYGO & .. & 7.5 & LAC & lower middle income & 2,242 & .. & .. & .. \\
\hline Peru & .. & E-A & .. & .. & $\begin{array}{l}\text { Option to withdraw } \\
50 \% \text { of account } \\
\text { before separation }\end{array}$ & 1991 & none & .. & mixed & 39 & 0.0 & LAC & upper middle income & 4,469 & 7.20 & .. & 59.9 \\
\hline Philippines & No & I-C & untaxed & .. & No reform & n.a. & none & n.a. & PAYGO & 68 & 4.3 & Asia & lower middle income & 1,752 & 9.70 & 3.20 & 43.4 \\
\hline Poland & n.a. & n.a. & n.a. & n.a. & n.a. & n.a. & $\mathrm{UI}$ & 42 & mixed & 61 & 10.1 & OECD & high income & 11,273 & 15.70 & & 27.6 \\
\hline Portugal & Yes & I-C & & .. & No reform & n.a. & dual & 79 & PAYGO & 54 & 7.9 & OECD & high income & 21,903 & 6.30 & 19.50 & 22.6 \\
\hline Puerto Rico & n.a. & n.a. & n.a. & n.a. & n.a. & n.a. & $\mathrm{UI}$ & & PAYGO & .. & 0.0 & LAC & high income & & & & \\
\hline Qatar & .. & I-C & & .. & & .. & none & n.a. & PAYGO & .. & 7.2 & MENA & high income & 69,754 & .. & .. & .. \\
\hline Romania & .. & I-C & fully & yes & $\begin{array}{l}\text { Introduction of } \\
\text { guarantee fund }\end{array}$ & 2003 & UI & 16 & mixed & .. & 4.0 & Transition & upper middle income & 7,500 & 7.00 & 32.30 & 34.4 \\
\hline Russian Federation & .. & I-C & fully & .. & & & dual & 12 & mixed & .. & 8.7 & Transition & upper middle income & 8,676 & 7.70 & .. & 46.1 \\
\hline Rwanda & .. & I-C & & 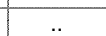 & & & none & n.a. & PAYGO & .. & 4.3 & Africa & low income & 506 & .. & .. & .. \\
\hline Samoa & n.a. & n.a. & n.a. & n.a. & n.a. & n.a. & none & n.a. & none & .. & 5.8 & Asia & lower middle income & 2,776 & .. & .. & .. \\
\hline Sao Tome and Principe & .. & $\mathrm{I}-\mathrm{C}$ & & .. & & & none & n.a. & PAYGO & .. & 4.3 & Africa & lower middle income & 1,184 & .. & 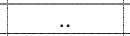 & \\
\hline Saudi Arabia & .. & I-C & untaxed & no & $\begin{array}{l}\text { Introduction of end } \\
\text { of-service benefit }\end{array}$ & 2005 & none & n.a. & PAYGO & .. & 4.3 & MENA & high income & 14,540 & 5.20 & 0.00 & .. \\
\hline Senegal & .. & $\mathrm{I}-\mathrm{C}$ & .. & .. & No reform & n.a. & none & n.a. & PAYGO & .. & 3.2 & Africa & lower middle income & 1,023 & 11.10 & .. & 43.2 \\
\hline Serbia & ... & $\mathrm{I}-\mathrm{C}$ & ... & .. & ... & .. & $\mathrm{UI}$ & ... & PAYGO & .. & 0.0 & Transition & upper middle income & 5,872 & .. & .. & .. \\
\hline Seychelles & ... & $\mathrm{I}-\mathrm{C}$ & .. & ... & ... & ... & none & n.a. & none & ... & 4.3 & Asia & upper middle income & 8,688 & .. & .. & .. \\
\hline Sierra Leone & .. & $\mathrm{I}-\mathrm{C}$ & $\ldots$ & ... & .. & ... & none & n.a. & PAYGO & n.a. & 8.7 & Africa & low income & 341 & & .. & \\
\hline Singapore & n.a. & n.a. & n.a. & n.a. & No reform & n.a. & none & n.a. & $\begin{array}{l}\text { Provident } \\
\text { fund }\end{array}$ & 13 & 3.0 & Asia & high income & 36,537 & 4.40 & 31.70 & 13.1 \\
\hline Slovak Republic & ... & $\mathrm{I}-\mathrm{C}$ & fully & ... & $\begin{array}{l}\text { No reform } \\
\end{array}$ & n.a. & $\mathrm{UI}$ & 32 & mixed & 56 & 11.6 & OECD & high income & 16,176 & 15.80 & 12.90 & 18.9 \\
\hline Slovenia & Yes & I-C & fully & yes & $\begin{array}{l}\text { Sev pay for } \\
\text { economic reasons } \\
\text { or reasons of } \\
\text { capacity }\end{array}$ & 2007 & $\mathrm{UI}$ & 27 & PAYGO & .. & 5.7 & OECD & high income & 23,726 & 5.90 & .. & 27.1 \\
\hline Solomon Islands & .. & $\mathrm{I}-\mathrm{C}$ & .. & .. & .. & .. & none & n.a. & $\begin{array}{l}\text { Provident } \\
\text { fund }\end{array}$ & n.a. & 4.3 & Asia & low income & 1,256 & .. & .. & .. \\
\hline South Africa & .. & $\mathrm{I}-\mathrm{C}$ & .. & .. & $\begin{array}{l}\text { Statutory sev pay } \\
\text { only in case of } \\
\text { redundancy }\end{array}$ & 1997 & $\mathrm{UI}$ & 6 & universal & .. & 4.0 & Africa & upper middle income & 5,786 & 26.40 & 39.80 & 28.4 \\
\hline Spain & Yes & $\mathrm{I}-\mathrm{C}$ & fully & .. & $\begin{array}{c}\text { Introduction of } \\
\text { benefit formula, } \\
\text { generosity } \\
\text { increased }\end{array}$ & 1995 & dual & 69 & PAYGO & 81 & 2.1 & OECD & high income & 31,774 & 10.60 & 14.50 & 22.6 \\
\hline Sri Lanka & No & I-C & .. & .. & $\begin{array}{l}\text { Introduction of } \\
\text { benefit formula }\end{array}$ & 2005 & UA & .. & $\begin{array}{l}\text { Provident } \\
\text { fund }\end{array}$ & .. & 4.3 & Asia & lower middle income & 2,068 & 7.40 & 6.00 & 44.6 \\
\hline St. Kitts and Nevis & n.a. & n.a. & n.a. & n.a. & n.a. & n.a. & none & n.a. & PAYGO & .. & 8.7 & LAC & upper middle income & 10,988 & .. & ... & .. \\
\hline St. Lucia & ... & I-C &.. & ... & ... & .. & none & n.a. & PAYGO & .. & 3.7 & LAC & upper middle income & 5,496 & .. & .. & .. \\
\hline $\begin{array}{l}\text { St. Vincent and the } \\
\text { Grenadines }\end{array}$ & .. & I-C & .. & .. & .. & & none & n.a. & PAYGO & .. & 4.0 & LAC & upper middle income & 5,335 & & & \\
\hline
\end{tabular}




\begin{tabular}{|c|c|c|c|c|c|c|c|c|c|c|c|c|c|c|c|c|c|}
\hline \multirow[b]{2}{*}{ Country } & \multicolumn{4}{|c|}{ Funding \& Taxation } & \multicolumn{2}{|l|}{ Reforms } & \multicolumn{4}{|c|}{ Other Income support } & \multirow{2}{*}{\begin{tabular}{|c|}
$\begin{array}{c}\text { Employment } \\
\text { Regulation }\end{array}$ \\
$\begin{array}{c}\text { Redundancy } \\
\text { Notice Period } \\
\text { (weeks) }\end{array}$ \\
\end{tabular}} & \multicolumn{6}{|c|}{ Country Background Variables } \\
\hline & $\begin{array}{l}\text { State } \\
\text { contri- } \\
\text { bution }\end{array}$ & $\begin{array}{l}\text { Funding } \\
\text { method }\end{array}$ & $\begin{array}{l}\text { Taxation } \\
\text { of } \\
\text { benefits }\end{array}$ & $\begin{array}{l}\text { Guaran- } \\
\text { tee fund }\end{array}$ & Type of reform & $\begin{array}{l}\text { Year of } \\
\text { reform }\end{array}$ & $\begin{array}{c}\text { Type of } \\
\text { unemploy- } \\
\text { ment } \\
\text { benefit } \\
\text { system }\end{array}$ & $\begin{array}{c}\text { Unem- } \\
\text { ployment } \\
\text { benefit } \\
\text { generosity }\end{array}$ & $\begin{array}{l}\text { Type of } \\
\text { Pension } \\
\text { system }\end{array}$ & $\begin{array}{c}\text { Pension } \\
\text { benefit } \\
\text { gene- } \\
\text { rosity }\end{array}$ & & Region & Income level & $\begin{array}{l}\text { GDP per } \\
\text { capita } \\
\text { (Current } \\
\text { US\$, 2009) }\end{array}$ & $\begin{array}{l}\text { Unem- } \\
\text { ployment } \\
\text { rate, 2000- } \\
2008(\%)\end{array}$ & $\begin{array}{c}\text { Trade } \\
\text { Union } \\
\text { Density } \\
\text { 2008-2009 }\end{array}$ & $\begin{array}{c}\text { Size of } \\
\text { informal } \\
\text { economy } \\
(\%)\end{array}$ \\
\hline Sudan & .. & I-C & .. & .. & .. & .. & none & n.a. & PAYGO & n.a. & 4.3 & Africa & lower middle income & 1,294 & .. & 0.00 & .. \\
\hline Suriname & .. & I-C & .. & ... &.. & ... & none & n.a. & none & n.a. & 0.0 & Asia & upper middle income & 5,888 & .. & .. & .. \\
\hline Swaziland & $\cdot \cdot$ & I-C & $\cdot \cdot$ & $\cdot \cdot$ & .. &.$\cdot$ & none & n.a. & $\begin{array}{l}\text { Provident } \\
\text { fund }\end{array}$ & n.a. & 5.9 & Africa & lower middle income & 2,533 & $\cdot \cdot$ & $\cdot \cdot$ & $\cdot \cdot$ \\
\hline Sweden & n.a. & n.a. & n.a. & n.a. & No reform & n.a. & dual & 66 & mixed & 62 & 14.4 & OECD & high income & 43,654 & 5.20 & 73.60 & 19.1 \\
\hline Switzerland & Yes & I-C & . & . & No reform & n.a. & UI & 80 & mixed & 58 & 10.1 & OECD & high income & 63,629 & 3.50 & 23.70 & 8.8 \\
\hline Syria & .. & I-C & .. & .. & No reform & n.a. & none & n.a. & PAYGO & ... & 8.7 & MENA & lower middle income & 2,474 & 11.40 & .. & .. \\
\hline Taiwan & .. & I-C & partially & .. & $\begin{array}{l}\text { Introduction of } \\
\text { benefit formula }\end{array}$ & 2005 & $\mathrm{UI}$ & 8 & PAYGO & 70 & 4.3 & Asia & high income & .. & 4.20 & 35.90 & 19.6 \\
\hline Tajikistan & .. & I-C & .. & .. & & .. & none & n.a. & PAYGO & .. & 8.7 & Transition & low income & 716 &.. & .. & .. \\
\hline Tanzania & .. & I-C & partially & .. & \begin{tabular}{|c|} 
Introduction of sev \\
pay
\end{tabular} & 2004 & none & n.a. & PAYGO & .. & 4.0 & Africa & low income & 509 & 5.10 & 18.70 & 58.3 \\
\hline Thailand & No & I-C & untaxed & yes & No reform & n.a. & $\mathrm{UI}$ &.. & PAYGO & 50 & 4.3 & Asia & lower middle income & 3,894 & 1.60 & 2.10 & 52.6 \\
\hline Timor-Leste & n.a. & n.a. & n.a. & n.a. & n.a. & n.a. & none & n.a. & none & n.a. & 4.3 & Asia & lower middle income & 492 & .. & .. & .. \\
\hline Togo & ... & I-C & & & & & none & n.a. & none & n.a. & 4.3 & Africa & low income & 431 & .. & .. & ... \\
\hline Tonga & n.a. & n.a. & n.a. & n.a. & n.a. & n.a. & none & n.a. & none & n.a. & 0.0 & Asia & lower middle income & 2,991 & .. & .. & .. \\
\hline Trinidad and Tobago & .. & I-C & 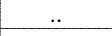 & 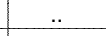 & & & none & n.a. & PAYGO & & 6.4 & LAC & high income & 15,841 & .. & .. & .. \\
\hline Tunisia & .. & $E-F$ & .. & .. & $\begin{array}{l}\text { Increase in } \\
\text { severance pay }\end{array}$ & 2002 & UA & 2 & PAYGO & 64 & 4.3 & MENA & lower middle income & 3,792 & 14.60 & .. & 38.4 \\
\hline Turkey & Yes & I-C & partially &.. & $\begin{array}{c}\text { Introduction of sev } \\
\text { pay }\end{array}$ & 2003 & $\mathrm{UI}$ & 46 & PAYGO & 87 & 6.7 & OECD & upper middle income & 8,215 & 9.70 & 25.10 & 32.1 \\
\hline Uganda & .. & I-C & .. & .. & \begin{tabular}{|c|} 
Severance pay \\
subject to \\
negotiation btw the \\
employer and the \\
workers or the \\
trade union \\
\end{tabular} & 2006 & none & n.a. & $\begin{array}{l}\text { Provident } \\
\text { fund }\end{array}$ & .. & 8.7 & Africa & low income & 490 & 3.20 & .. & 43.1 \\
\hline Ukraine &.. & I-C & fully & & \begin{tabular}{|l|} 
No reform \\
\end{tabular} & n.a. & UI & 15 & PAYGO & .. & 8.7 & Transition & lower middle income & 2,468 & 8.50 & & 52.2 \\
\hline United Arab Emirates & no & I-C & untaxed & no & & & none & n.a. & PAYGO & .. & 4.3 & MENA & high income & 50,070 & & 0.00 & 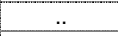 \\
\hline United Kingdom & Yes & I-C & partially & .. & $\begin{array}{l}\text { Statutory sev pay } \\
\text { only in case of } \\
\text { redundancy }\end{array}$ & 1996 & dual & 28 & mixed & 31 & 5.3 & OECD & high income & 35,165 & 5.10 & .. & 12.6 \\
\hline United States & n.a. & n.a. & n.a. & n.a. & No reform & n.a. & UI & 28 & PAYGO & 39 & 0.0 & OECD & high income & 45,989 & 5.10 & 11.40 & 8.8 \\
\hline Uruguay & .. & I-C & & $\ldots$ & No reform & n.a. & UA & 5 & mixed & 103 & 0.0 & LAC & upper middle income & 9,420 & 13.50 & 19.00 & 51.1 \\
\hline Uzbekistan & .. & I-C & fully & .. & No reform & n.a. & $\mathrm{UI}$ & 6 & PAYGO & & 8.7 & Transition & lower middle income & 1,156 & .. & .. & .. \\
\hline Vanuatu & .. & I-C & .. & .. & ... & .. & none & n.a. & PAYGO & n.a. & 9.3 & Asia & lower middle income & 2,702 & .. & .. & .. \\
\hline Venezuela & .. & I-B, E-A & partially & .. & $\begin{array}{c}\text { Introduction of } \\
\text { severance } \\
\text { accounts }\end{array}$ & 1997 & UI & 6 & PAYGO & .. & .. & LAC & upper middle income & 11,490 & 12.00 & .. & 33.6 \\
\hline Vietnam & .. & I-C & untaxed & & $\begin{array}{l}\text { Introduction of sev } \\
\text { pay }\end{array}$ & 2003 & UI & .. & PAYGO & 68 & 0.0 & Transition & lower middle income & 1,032 & 2.30 &.. & 15.6 \\
\hline West Bank and Gaza & .. & I-C & & & & & none & n.a. & PAYGO &.. & 4.3 & MENA & lower middle income & & .. & .. & .. \\
\hline Yemen & .. & I-C & .. & & $\begin{array}{c}\text { Introduction of sev } \\
\text { pay }\end{array}$ & 1995 & none & n.a. & PAYGO & .. & 4.3 & MENA & lower middle income & 1,118 & 15.40 &.. & .. \\
\hline
\end{tabular}




\begin{tabular}{|c|c|c|c|c|c|c|c|c|c|c|c|c|c|c|c|c|c|}
\hline \multirow[b]{2}{*}{ Country } & \multicolumn{4}{|c|}{ Funding \& Taxation } & \multicolumn{2}{|c|}{ Reforms } & \multicolumn{4}{|c|}{ Other Income support } & \multirow{2}{*}{\begin{tabular}{|c|}
$\begin{array}{c}\text { Employment } \\
\text { Regulation }\end{array}$ \\
Redundancy \\
Notice Period \\
(weeks)
\end{tabular}} & \multicolumn{6}{|c|}{ Country Background Variables } \\
\hline & $\begin{array}{c}\text { State } \\
\text { contri- } \\
\text { bution }\end{array}$ & $\begin{array}{l}\text { Funding } \\
\text { method }\end{array}$ & $\begin{array}{c}\text { Taxation } \\
\text { of } \\
\text { benefits }\end{array}$ & $\begin{array}{l}\text { Guaran- } \\
\text { tee fund }\end{array}$ & Type of reform & $\begin{array}{l}\text { Year of } \\
\text { reform }\end{array}$ & $\begin{array}{c}\text { Type of } \\
\text { unemploy- } \\
\text { ment } \\
\text { benefit } \\
\text { system }\end{array}$ & $\begin{array}{c}\text { Unem- } \\
\text { ployment } \\
\text { benefit } \\
\text { generosity }\end{array}$ & $\begin{array}{l}\text { Type of } \\
\text { Pension } \\
\text { system }\end{array}$ & $\begin{array}{c}\text { Pension } \\
\text { benefit } \\
\text { gene- } \\
\text { rosity }\end{array}$ & & Region & Income level & $\begin{array}{l}\text { GDP per } \\
\text { capita } \\
\text { (Current } \\
\text { US\$, 2009) }\end{array}$ & $\begin{array}{l}\text { Unem- } \\
\text { ployment } \\
\text { rate, 2000- } \\
2008(\%)\end{array}$ & $\begin{array}{c}\text { Trade } \\
\text { Union } \\
\text { Density } \\
\text { 2008-2009 }\end{array}$ & $\begin{array}{c}\text { Size of } \\
\text { informal } \\
\text { economy } \\
(\%)\end{array}$ \\
\hline Zambia & .. & I-C & .. & .. & No reform & n.a. & none & n.a. & PAYGO & .. & 4.3 & Africa & low income & 985 & .. & .. & 48.9 \\
\hline Zimbabwe &.. & I-C & .. & .. & No reform & n.a. & none & n.a. & PAYGO & & 13.0 & Africa & low income & .. & .. & & 59.4 \\
\hline
\end{tabular}




\section{Notes and Sources}

\section{Legal base}

Statutory $=1$ if the country has a legally mandated severance pay system, 0 if not.

Determined by Collective Agreements $=1$ if severance payments are determined through collective agreements in a sitnificant manner, 0 if not.

\section{Coverage}

Sectors $=p$ if only private sector is covered by severance pay programs in the country, a if both private and public sectors are covered.

Excluded categories refer to the categories of workers to which the legislation under review do not apply.

\section{Eligible Contingencies}

Type of termination payment refers to the reasons for employment termination that make the worker eligible to receive severance payment (statutory or otherwise); coded as follows: $\mathrm{D}=$ Dismissal/Involuntary separation (Valid reasons other than economic as provided by the employer) ; R=Redundancy (Economic reasons, Redundancy, Reduction of staff, Retrenchment, Reorganization, Restructuring, Structural changes, Technological change); E= End of service/Voluntary separation (End of contract term, Quits, Voluntary quits, Resignation due to economic condition, Military service, Enters school, Family-related issues); $\mathrm{O}=\mathrm{Old}$ Age/Retirement ; I=Incapacity/Disability (Worker's incapacity to work due to incompetence or health reasons: illness or permanent disability); $\mathrm{B}=$ Bankruptcy/Closure of Organization/Insolvency (Bankruptcy, Business rationalization, Cessation of business, Closure of firm, Organization dissolved/ moved, Liquidation).

\section{Defined Benefits for Redundency}

Minimum months' employment to qualify refers to the number of months the worker should have worked for the current employer to qualify for severance payment.

9 months refers to severance payment (in weeks of salary) made in case of redundancy dismissal of worker with tenure of 9 months.

1 years refers to severance payment (in weeks of salary) made in case of redundancy dismissal of worker with tenure of 1 year.

5 years refers to severance payment (in weeks of salary) made in case of redundancy dismissal of worker with tenure of 5 years.

10 years refers to severance payment (in weeks of salary) made in case of redundancy dismissal of worker with tenure of 10 years.

20 years refers to severance payment (in weeks of salary) made in case of redundancy dismissal of worker with tenure of 20 years.

Generosity index $=$ average per year of service for employees with 1, 5 and 10 years of service (in weeks of salary)

\section{End-of-service pay}

Minimum months' employment to qualify refers to the number of months the worker should have worked for the current employer to qualify for severance payment.

Generosity index $=$ average per year of service for employees with 20 years of service 


\section{Defined Contribution}

Minimum months' employment to qualify refers to the number of months the worker should have worked for the current employer to qualify for severance payment.

Contribution rate refers to the percentage of employee's salaray taken as contribution to the severance payment account or fund.

\section{Funding \& Taxation}

State contribution indicates whether firms receive any assistance from the State; coded Yes/No Funding method indicates how firms finance severance pay; coded as follows: I-C: Internal-Cash Flows; I-B: Internal-Book reserves; E-A: External-Individual Accounts; E-F: External-

Centralized Fund

Taxation of benefits indicates the extent to which worker benefits are taxed and employer expenses deductible; coded as follows: a) Workers fully taxed b) Workers partially taxed c) Workers not taxed d) Employer expenses not deductible e) Employer expenses partially deductible.

Guarantee fund: yes, no

\section{Other income support}

Type of unemployment insurance system: UI= Unemployment Insurance; UA=Unemployment Benefits

Unemployment benefits generosity: Gross Replacement Rate for Average Incoem Worker.

Type of pension system: universal, PAYGO=pay-as-you-go system; funded; mixed=both; Provident fund

Pension benefits generosity: Gross replacement rate for average inomce earner (OECD APEX model)

\section{Employment regulation}

Redundancy notice: Average weeks for workers with 1,5 and 10 years of service (WB, Doing business)

\section{Country Background variables}

Income level is according to World Bank classification system

Unemployment rate is the average unemployment rate in the country over the period 2000-2005, except in the following cases: Azerbaijan - rate is for 2003, Ethiopia - rate is for 2005, India rate is

for 2000, Iran - rate is for 2005, Mali - rate is for 2004, Tanzania - rate is for 2001, Zambia - rate is for 2000 .

Trade Union Density refers to the ratio of union members earning wages over total wage and salary earners.

Estimated size of informal economy refers to the size of the informal economy as a percentage of GDP (varying time periods).

Share of informal labor refers to the share of the total labor force employed in the informal economy in the capital city of each country as a percent of the official labor force. 


\section{Sources}

\section{Severance pay and dismissal process:}

Angel-Urdinola and Kuddo (2010); Holzmann and Pouget (2011); ILO EPLex (2011); ILONATLEX (various years); ILO Termination of Employment Digest (2011); Kuddo (2009); Mercer (www.mercer.us); OECD Employment Protection Indicators (2008); OECD Employment Outlook (various years); World Bank (2010): Doing Business, Towers Watson Employment Terms and Conditions (2010).

Other income support and country background variables:

Unemployment Insurance: OECD (1999); Social Security Programs throughout the World (2008-2010); Pensions: OECD (2010): Pensions at a Glance, OECD (2008): Pensions at a Glance - Asia-Pacific; World Bank (2007): Pension Panorama; Region, Income level, GDP per capita: World Development Indicators, World Bank (2011); Unemployment rate: LABORSTA, ILO (www.laborsta.ilo.org); Trade Union Density: ILO 2008-2009; Estimated size of informal economy, Share of Informal Labor: Botero, Djankov, La Porta, Lopez de Silanes and Shleifer (2004). 


\section{ANNEX 3: Note on Econometric Estimation}

This Annex provides a brief explanation of the 2 key aspects of the econometric explanation in Section 4.2: The use of robust regression, and a summary of critical factors.

\section{Why robust regression?}

Robust regression methods are less affected by violations of some of the assumptions underlying ordinary least squares (OLS) estimation. This means they are less influenced by outliers or other influential observations and heteroscedasticity. However, a deviation from independence and/or normality of error terms (e.g. due to skewness) should be dealt with differently.

In this dataset, especially skewness may be an issue, as several income-related variables are included (GDP per capita and variants, generosity indices). For GDP per capita we overcome skewness by using $\log$ (GDP per capita) instead. For generosity indices a logarithmic transformation is not possible because of the (large number of) zero generosity values. We experimented with square roots of the dependent variable. This only had an effect on the results of tests of the normality assumption, but not on the overall results in terms of relevance and statistical significance of explanatory variables.

The function "Imrob" of R (2010) CRAN package "robustbase" (Rousseeuw et al. 2009) is used to analyze the data. lmrob computes fast MM-estimators for linear regression based on Yohai (1987). It uses an S-estimator (Rousseeuw and Yohai, 1984) for the errors which is also computed with a bi-square score function. The S-estimator is computed using the Fast-S algorithm of Salibian-Barrera and Yohai (2006). Standard errors are computed using the formulas of Croux, Dhaene and Hoorelbeke (2003).

\section{References}

Croux, C., Dhaene, G. and Hoorelbeke, D. 2003. Robust standard errors for robust estimators, Discussion Papers Series 03.16, K.U. Leuven, CES.

R Development Core Team. 2010. R: A language and environment for statistical computing. R Foundation for Statistical Computing, Vienna, Austria. ISBN 3-900051-07-0, http://www.R-project.org.

Rousseeuw, P.J., Croux, C., Todorov, V., Ruckstuhl, A., Salibian-Barrera, M., Verbeke, T., and Maechler, M. 2009. robustbase: Basic Robust Statistics. R package version 0.5-0-1. http://CRAN.Rproject.org/package $=$ robustbase.

Rousseeuw, P.J. and Yohai, V.J. 1984. Robust regression by means of S-estimators, In Robust and Nonlinear Time Series, J. Franke, W. Härdle and R. D. Martin (eds.). Lectures Notes in Statistics 26, 256-272, Springer Verlag, New York.

Salibian-Barrera, M. and Yohai, V.J. 2006. A fast algorithm for S-regression estimates, Journal of Computational and Graphical Statistics, in press.

Yohai, V.J. 1987. High breakdown-point and high efficiency estimates for regression. The Annals of Statistics 15, 642-65.

\section{Summary of Critical Aspects}

Besides robust regression we rely on OLS estimation. For the latter, the following model assumptions were examined.

Independence of error terms: This assumption is especially relevant for time series (autocorrelation). For cross-section (non-time series) data, it can be checked by means of plotting 
residuals vs. independent variables. For the data analyzed in this paper, these charts indicate independence of error terms.

Homoscedasticity (variance homogeneity) of error terms: Charts of (standardized) residuals vs. fitted values or the square root of standardized residuals vs. fitted values show high residuals for many models, especially for those with only 1 or 2 explanatory variables that include most observations. For some models the charts indicate the existence of heteroscedasticity with higher variability of residuals for larger fitted values. However, neither the Goldfeld-Quandt test (1965) nor the Breusch-Pagan test (1979) show significant deviation from the homogeneous variance assumption at the 5\% level for any model with Severance Pay Generosity as response variable. For the dichotomous response variable, the Goldfeld-Quandt test indicates significant heteroscedasticity for three models, but this result is not confirmed by the Breusch-Pagan test. Therefore, variance inhomogeneity does not seem to be a problem overall. The Ramsey RESET test (1969) test is not significant $(\alpha=0.05)$ for the models analyzed, implying the validity of the results of the two tests for homoscedasticity.

Standard normal distribution of error terms: For hardly any model the normality distribution assumption is satisfied. Most Q-Q plots indicate higher skewness and/or heavier tails. JarqueBera tests (1987) confirm this observation. However, linear regression is fairly robust against non-normality in case of reasonable sample sizes based on the central limit theorem. Using log (GDP per capita) is a step towards normality of residuals by reducing the skewness of their distribution. The logarithm or the square root (to avoid issues with zeros) may also be applied to the different generosity index variables used in the model, even to the response variable. However, as already stated above, the results of the Jarque-Bera test improve but the relevance and significance of explanatory variables hardly change for any model when using the square root of Severance Pay Generosity Index.

Linearity of relation between dependent and independent variables: Only very few potential explanatory variables show (bivariate) correlation with the response variables. The only significant $(\alpha=0.05)$ linear correlation coefficients between Severance Pay Generosity Index and the explanatory variables are those involving $\log$ (GDP per capita) and the indicator variables for Income Level = high and low, respectively. Actually, the correlation between the regressors is stronger (multi-collinearity) than between most regressors and the response variables. Although multivariate correlation may still exist, the explanatory variables with the weakest pairwise correlation with the response variables in terms of significance and absolute value turn out to rarely have significant coefficients in the regression models either. In addition, scatterplots indicate that excluding the observations with unemployment benefit generosity, pension benefit generosity, and severance pay generosity equal to 0 might reveal linear relations between the variables in the remaining countries. This may help overcome the deviation from the linearity assumption.

Goodness of fit: Another way of validating the linearity of the relation between response and explanatory variables is evaluating the goodness of fit of a linear regression. In addition to conventional goodness of fit measures such as (adjusted) $\mathrm{R}$ squared and various information criteria (e.g. AIC (Akaike, 1974), BIC (Schwarz, 1978), etc.) a simple scatterplot of fitted vs. observed values of the dependent variable helps to assess the goodness of fit of a regression model. In the basic model set, most models have inacceptable levels of the goodness of fit measures which is also visible in the charts. Only models with multiple explanatory variables show a reasonable goodness of fit, but have the drawback of a reduced number of observations 
due to missing values. Some of the larger models even shrink the number of observations to approx. $20-25 \%$ of the original sample size. These models include merely OECD countries with a rather high GDP per capita. A generalization of results, thus, seems not valid, as income (GDP per capita) and OECD membership are correlated as well as income and the response variable Severance Pay Generosity. Groupwise models based on Income level or Region are an option here, although splitting the incomplete dataset further decreases the number of observations usable by a model. An analysis by region or income level is favorable. The smaller models can be calculated for larger samples but hardly have any explanatory / predictive power and are thus not to be used. The variable $\log$ (GDP per capita) is one of the few consistently significant variables.

Absence of multi-collinearity of independent variables: A correlation analysis in combination with a scatterplot matrix of the independent variables helps detect pairwise collinearity. Multicollinearity can be determined by (generalized) variance inflation factors (VIFs) (Fox and Monette, 1992). VIFs measure the effect of multi-collinearity on the variance of the regression coefficient of an explanatory variable.

Correlation analysis as well as VIFs show that multi-collinearity is present in the analyzed dataset. Apart from Trade Union Density and Notice Period (weeks) all metric variables are pairwise correlated. Including indicator variables of the categorical explanatory variables in the correlation analysis shows that these two variables as well as the indicator variables for Type of Unemployment Benefit $=$ UA and Region $=$ MENA are not significantly correlated to the other explanatory variables. Still, the majority of the correlation coefficient is smaller than 0.4 , which indicates that pairwise collinearity is not as severe. Generalized variance inflation factors indicate that $\log$ (GDP per capita), Income level, and Unemployment Benefit Generosity are the regressors most heavily affected by multi-collinearity. It is advisable to avoid using them all together in one model. Especially models that include Income level and/or Region in addition to a GDP per capita variable may be problematic.

\section{References}

Akaike, H. 1974. "A new look at the statistical model identification". IEEE Transactions on Automatic Control 19 (6): 716-723.

Breusch, T.S.; Pagan, A.R. 1979. "Simple test for heteroscedasticity and random coefficient variation". Econometrica (The Econometric Society) 47 (5): 1287-1294.

Fox, J. and Monette, G. 1992. Generalized collinearity diagnostics. JASA, 87, 178-183.

Goldfeld, Stephen M.; Quandt, R. E. 1965. "Some Tests for Homoscedasticity". Journal of the American Statistical Association 60 (310): 539-547.

Jarque, Carlos M.; Bera, Anil K. 1987. "A test for normality of observations and regression residuals". International Statistical Review 55 (2): 163-172.

Ramsey, J.B. (1969) "Tests for Specification Errors in Classical Linear Least Squares Regression Analysis", J. Roy. Statist. Soc. B., 31(2), 350-371.

Schwarz, G.E. (1978). "Estimating the dimension of a model". Annals of Statistics 6 (2): 461-464. 